Florida International University FIU Digital Commons

6-10-2013

\title{
An Assessment of Novel Biodegradable Magnesium Alloys for Endovascular Biomaterial Applications
}

Dharam Persaud-Sharma

Florida International University, Dpers001@fiu.edu

DOI: $10.25148 /$ etd.FI13080712

Follow this and additional works at: https://digitalcommons.fiu.edu/etd

Part of the Biomaterials Commons, Biomedical Devices and Instrumentation Commons, Equipment and Supplies Commons, Surgical Procedures, Operative Commons, and the Therapeutics Commons

\section{Recommended Citation}

Persaud-Sharma, Dharam, "An Assessment of Novel Biodegradable Magnesium Alloys for Endovascular Biomaterial Applications" (2013). FIU Electronic Theses and Dissertations. 950.

https://digitalcommons.fiu.edu/etd/950 


\section{FLORIDA INTERNATIONAL UNIVERSITY \\ Miami, Florida}

\section{AN ASSESSMENT OF NOVEL BIODEGRADABLE MAGNESIUM ALLOYS FOR ENDOVASCULAR BIOMATERIAL APPLICATIONS}

A dissertation submitted in partial fulfillment of the

requirements for the degree of

DOCTOR OF PHILOSOPHY

in

BIOMEDICAL ENGINEERING

by

Dharam Persaud-Sharma

2013 
To: Dean Amir Mirmiran

College of Engineering and Computing

This dissertation, written by Dharam Persaud-Sharma, and entitled An Assessment of Novel Biodegradable Magnesium Alloys for Endovascular Biomaterial Applications, having been approved in respect to style and intellectual content, is referred to you for judgment.

We have read this dissertation and recommend that it be approved.

$\begin{array}{r}\hline \text { Yen-Chih Huang } \\ \hline \text { Wei-Chiang Lin } \\ \hline \text { Sergio Gonzalez-Arias } \\ \hline \text { Anthony J. McGoron, Major Professor }\end{array}$

Date of Defense: June 10, 2013

The dissertation of Dharam Persaud-Sharma is approved.

Dean Amir Mirmiran

College of Engineering and Computing

Dean Lakshmi N. Reddi

University Graduate School

Florida International University, 2013 
(C) Copyright 2013 by Dharam Persaud-Sharma

All rights reserved. 


\title{
DEDICATION
}

I dedicate this dissertation to many different individuals and groups of people. Most importantly, I dedicate this work to my mother and forefathers, and I thank them for giving me the strength to persevere through times of hardship throughout my life. Mom, you've been my guiding light, my inspiration, and I love you.

To the boys and girls of single-parents, living in poverty, caught in the struggle...I dedicate this work to you. It serves as a testament that although you may feel forgotten and often betrayed throughout periods of your life, you should never give up and never surrender your aspirations or dreams to anyone. More people will expect you to fail, insult you at any chance they can, undermine your-being and make you feel worthless at times. Don't ever let that stop you. Keep moving forward toward your life-goals with more hunger and desire than before. Never let someone define for you what you can and cannot do. That is for you to decide, and only you.

To the surviving victims of brain aneurysms, their families and the ones who were lost too soon.

\begin{abstract}
And lastly
“...Here's to the crazy ones, the misfits, the rebels, the troublemakers, the round pegs in the square holes... the ones who see things differently -- they're not fond of rules... You can quote them, disagree with them, glorify or vilify them, but the only thing you can't do is ignore them because they change things... they push the human race forward, and while some may see them as the crazy ones, we see genius, because the ones who are crazy enough to think that they can change the world, are the ones who do."
\end{abstract}

$\sim$ Steve Jobs (Innovator and Entrepreneur, 1955-2011) 


\section{ACKNOWLEDGMENTS}

I first embarked on the journey of seeking higher education under the false impression that graduate school was a haven for intellectuals and was a place where a kid who fancied science could run wild with boundless knowledge. While I am sure that a scientific euphoria exists somewhere and some people have been blessed to experience even a fraction of its promise, I certainly was not fortunate to be in such a wonderland.

I was not fortunate to have an advisor to work with on this project or throughout graduate school. I do not have a lab group to thank, because I was never part one. However, I would like to thank Dr. Noah Budiansky for facilitating an environment for me to collect some of my data. For the students who always ask me for advice, I say to them that it would be ideal to work with someone who is trained in the field of your research interests, and someone who can mentor and offer you meaningful advice about your project and career.

A research fellowship providing me with financial support for the past four years from the National Institute of Health and the MBRS RISE program with Dr. Charles Bigger first created the opportunity for me to explore science on my own terms. It allowed me to develop my own project and work in an area of self-interest throughout graduate school, which is something that graduate students very rarely have an opportunity to experience.

One of the main problems I encountered creating my own project and being financially supported through a fellowship to conduct research, was the lack of lab space to actually perform the research and the funds to purchase materials and supplies. Receiving a research grant from the National Brain Aneurysm Foundation as the 
Principal Investigator, based upon a grant proposal that I solely authored and a project that I solely developed made this dissertation possible. Without this financial support, such valuable research would not be shared with the world. I clearly recall when absolutely no faculty members wanted to fund my research endeavors and the ones who literally laughed in my face at merely proposing my idea for research; it was a scientific council comprised of leading scientists and clinicians in the field of cerebrovascular research who saw the merit of my proposal. Without such funding, this project and the novel magnesium alloys $\mathrm{Mg}-\mathrm{Zn}-\mathrm{Se}$ and $\mathrm{Mg}-\mathrm{Zn}-\mathrm{Cu}$ alloys I created, would never have seen the light of day. I would like to thank my friends at Hysitron Corp., Exponent, the University of South Florida and the University of Central Florida for their hospitality during my visits to conduct experiments using their research facilities.

Lastly, I would like to thank Dr. Michael Brown, for being a wonderful humanbeing, friend, and mentor and someone who has truly changed my life for the better. I would also like to acknowledge my friend Neal Ricks, the facility director of the Advanced Materials Engineering Research Institute (AMERI), who helped to accommodate my research needs and community outreach initiatives in any way that he could.

"Kites rise highest against the wind-not with it."

$\sim$ Sir Winston Churchill (1874-1965) 


\title{
ABSTRACT OF THE DISSERTATION \\ AN ASSESSMENT OF NOVEL BIODEGRADABLE MAGNESIUM ALLOYS FOR ENDOVASCULAR BIOMATERIAL APPLICATIONS
}

by

\author{
Dharam Persaud-Sharma
}

Florida International University, 2013

Miami, Florida

\section{Professor Anthony J. McGoron, Major Professor}

Magnesium alloys have been widely explored as potential biomaterials, but several limitations to using these materials have prevented their widespread use, such as uncontrollable degradation kinetics which alter their mechanical properties. In an attempt to further the applicability of magnesium and its alloys for biomedical purposes, two novel magnesium alloys $\mathrm{Mg}-\mathrm{Zn}-\mathrm{Cu}$ and $\mathrm{Mg}-\mathrm{Zn}-\mathrm{Se}$ were developed with the expectation of improving upon the unfavorable qualities shown by similar magnesium based materials that have previously been explored. The overall performance of these novel magnesium alloys has been assessesed in three distinct phases of research:

1) analysing the mechanical properties of the as-cast magnesium alloys, 2) evaluating the biocompatibility of the as-cast magnesium alloys through the use of in-vitro cellular studies, and 3) profiling the degradation kinetics of the as-cast magnesium alloys through the use of electrochemical potentiodynamic polarization techqnique as well as gravimetric weight-loss methods. As compared to currently available shape memory alloys and degradable as-cast alloys, these experimental alloys possess superior as-cast mechanical properties with elongation at failure values of $12 \%$ and $13 \%$ for the $\mathrm{Mg}-\mathrm{Zn}$ - 
Se and Mg-Zn-Se alloys, respectively. This is substantially higher than other as-cast magnesium alloys that have elongation at failure values that range from $7-10 \%$. Biocompatibility tests revealed that both the Mg-Zn-Se and $\mathrm{Mg}-\mathrm{Zn}-\mathrm{Cu}$ alloys exhibit low cytotoxicity levels which are suitable for biomaterial applications. Gravimetric and electrochemical testing was indicative of the weight loss and initial corrosion behavior of the alloys once immersed within a simulated body fluid. The development of these novel as-cast magnesium alloys provide an advancement to the field of degradable metallic materials, while experimental results indicate their potential as cost-effective medical devices. 
TABLE OF CONTENTS

CHAPTER $\quad$ PAGE

CHAPTER 1

INTRODUCTION

1.1 PROBLEM OF INQUIRY AND RESEARCH FOCUS

1.2 AIMS AND OBJECTIVES 9

1.3 REFERENCES 11

CHAPTER 2

LITERATURE REVIEW

2.1 INTRODUCTION 15

2.1.1. GENERAL APPLICATIONS 16

2.2 MAGNESIUM ALLOYS WITH TRACE ELEMENTS 16

2.2.1 MATERIAL STRUCTURE 16

2.2.2 IMPURITIES WITHIN MAGNESIUM 18

2.2.3 IMPURITIES AND CORROSION EFFECTS 18

2.2.4 MAGNESIUM AND CORROSIVES 20

2.2.5 MAGNESIUM AND HUMIDITY 21

2.3 ALLOYING ELEMENTS $\quad 21$

2.3.1 MANGANESE 21

2.3.2 COPPER 22

2.3.3 ALUMINUM 23

2.3.4 ZINC 23

2.4 MAGNESIUM AND ITS ALLOYS- CORROSION STUDIES USING

POTENTIODYNAMIC AND ELECTRICAL IMPEDANCE SPECTROSCOPY 25

2.4.1 NEGATIVE DIFFERENCE EFFECT

2.4.2 MAGNESIUM CORROSION: OXIDATION-REDUCTION 27

2.4.3 MAGNESIUM CORROSION MECHANISMS 29

2.4.4 ELECTROCHEMICAL CORROSION MODEL 31

2.4.5 NON-ELECTROCHEMICAL TESTING METHODOLOGY 32

2.4.6 ELECTROCHEMICAL TESTING METHODOLOGY 33

2.4.7 CYCLIC POLARIZATION AND ELECTRICAL IMPEDANCE SPECTROSCOPY EXPERIMENTS IN

ORGANIC ELECTROLYTE MEDIA $\quad 35$

2.5 CONCLUSIONS AND SUGGESTED RESEARCH 36

2.6 REFERENCES $\quad 37$

CHAPTER 3

MECHANICAL PROPERTIES AND TENSILE FAILURE ANALYSIS OF NOVEL BIO-ABSORBABLE MG-ZN-CU AND MG-ZN-SE ALLOYS 44 3.1 INTRODUCTION $\quad 44$

3.2 MATERIALS AND METHODS 46 
3.2.1 ALLOY MANUFACTURING AND SAMPLE PREPARATION 46

3.2.2 XPS ANALYSIS $\quad 46$

3.2.3 NANOINDENTATION ANALYSIS $\quad 47$

3.2.4 MATERIAL DENSITY CALCULATION 48

3.2.5 TENSILE TESTING 48

3.2.6 FRACTURE ANALYSIS BY SCANNING ELECTRON MICROSCOPY
AND ENERGY DISPERSIVE X-RAY SPECTROSCOPY

3.3 RESULTS 50

3.3.1 MECHANICAL PROPERTIES OF BARE ALLOYS AND AIR FORMED OXIDE LAYER USING NANOINDENTATION 50

3.3.2 EVALUATION OF MECHANICAL PROPERTIES 53

3.3.3 FRACTURE ANALYSIS

3.4 DISCUSSION 61

3.5 CONCLUSIONS $\quad 69$

3.6 REFERENCES $\quad 70$

CHAPTER 4

BIOCOMPATIBILITY ASSESSMENT OF NOVEL BIORESORBABLE ALLOYS MG-ZN-CU AND MG-ZN-SE $\quad 73$

4.1 INTRODUCTION $\quad 73$

4.2 MATERIALS AND METHODS 75

4.2.1 ALLOY MANUFACTURING AND SAMPLE PREPARATION 75

4.2.2 ALLOY SAMPLE SURFACE CHARACTERIZATION 76

4.2.3 MTS ASSAY

4.2.4 FLUORESCENT IMAGING $\quad 79$

$\begin{array}{ll}\text { 4.2.5 LDH QUANTIFICATION } & 79\end{array}$

4.2.6 DIRECT CONTACT ASSAY $\quad 80$

4.2.7 SEM IMAGING PREPARATION $\quad 81$

4.2.8 STATISTICAL ANALYSIS $\quad 81$

4.3 RESULTS $\quad 82$

4.3.1 SURFACE PROPERTIES OF TERNARY MAGNESIUM ALLOYS $\quad 82$

4.3.2 CELL VIABILITY: MTS ASSAY 84

4.3.3 PERCENT CYTOTOXICITY: LDH QUANTIFICATION, DIRECT CONTACT ASSAY, AND CELLULAR ADHESION 88

4.4 DISCUSSION 93

4.5 CONCLUSIONS 102

4.6 REFERENCES 103

CHAPTER 5

IN-VITRO DEGRADATION BEHAVIOR OF TERNARY MG-ZN-SE AND

MG-ZN-CU ALLOYS AS BIOMATERIALS 107

$\begin{array}{ll}5.1 \text { INTRODUCTION } & 107\end{array}$

5.2 MATERIALS AND METHODS 110

5.2.1 ALLOY MANUFACTURING AND SAMPLE PREPARATION 110

5.2.2 ELECTROCHEMICAL TESTING PROCEDURES 110 
5.2.3 TAFEL EXTRAPOLATION FROM VOLTAMMETRY CURVES

112

5.2.4 GRAVIMETRIC WEIGHT LOSS TESTS

112

5.2.5 INDUCTIVELY COUPLED PLASMA-MASS SPECTROMETRY ANALYSIS

113

5.3 RESULTS

114

5.4 DISCUSSION

125

5.5 CONCLUSIONS

129

5.6 REFERENCES

130

CHAPTER 6

SUMMARY

133

VITA

136 


\section{LIST OF TABLES}

TABLES

PAGE

Table 1-1 Bare Metal Stent Mechanical Properties $\quad 6$

Table 1-2 Mechanical Properties of Polymeric Stents 6

Table 1-3 Mechanical Properties of Magnesium Stents 7

Table 3-1Composition of Ternary Magnesium Alloys 46

Table 3-2 Mechanical Properties of Ternary Magnesium Alloys 49

Table 3-3 Tensile Properties of Ternary Magnesium Alloys at Room Temperature $\left(25^{\circ} \mathrm{C}\right) \quad 55$

Table 4-1 Weight Percentage of Alloy Compositions 76

Table 4-2 Surface Properties of Ternary Magnesium Alloys 83

Table 5-1 Comparison of Ion Concentration for Kokubo's Solution Human Blood Plasma, and Dulbecco's Modified Eagles Medium

Table 5-2 Weight Percentage of Alloy Compositions (Wt. \%)

Table 5-3 Corrosion Rates for Magnesium Alloys Determined by Electrochemical and Gravimetric Methods, Stent Strut Thickness and Degradation Time Estimates 


\section{LIST OF FIGURES}

FIGURE

PAGE

Figure 1-1 Comparison of mechanical properties for different

stent materials. Logarithmic scale, MPa. Polymers:

Poly-L-Lactide (PLLA); Polydiaxanone (PDS);

Poly(glycolide-co-caprolactone)(PGACL)

Figure 1-2 Typical process to manufacture a cardiovascular stent

Figure 2-1 Tafel kinetic plot showing theNegative Difference Effect

(NDE) compared to normal predictive behavior expected

for metals by tafel theory

Figure 2-2 Microphotograph of the magnesium surface after performing polarization analysis in $\mathrm{NaCl}$ solution $(50 \mathrm{x})$

Figure 2-3 Schematic Illustrating different corrosion mechanisms for Magnesium

Figure 2-4 Log i versus potential polarization curve made for AZ31 alloy in Phosphate Buffer Saline $+0.1 \mathrm{~g} / \mathrm{L}$ albumin

Figure 3-1 SEM Images and XPS Analysis of Oxide Layer Formation on the Mg-Zn-Se Alloy

Figure 3-2 SEM Images and XPS Analysis of Oxide Layer Formation on the $\mathrm{Mg}-\mathrm{Zn}-\mathrm{Cu}$ Alloy

Figure 3-3 Comparative SEM Cross-Sectional Images for Magnesium Alloys after Normal Tensile Failure

Figure 3-4 Optical Images of Tensile Specimens after Fracture

Figure 3-5 Mg-Zn-Cu Alloy with Normal Failure showing $\mathrm{Cu}$ along Boundaries of Failure

Figure 3-6 Mg-Zn-Se Alloy Casting Defect in Tensile Specimen Leading to Premature Failure

Figure 3-7 Mg-Zn-Cu Alloy Casting Defect in Tensile Specimen Leading to Premature Failure 
Figure 3-8 Stress-Strain Behavior from Tensile Testing of $\mathrm{Mg}-\mathrm{Zn}-\mathrm{Cu}$

and Mg-Zn-Se Alloys Compared to Martensitic Nitinol

Figure 4-1 Cell viability of human foreskin fibroblast cells when cultured in 100\% concentrated 30-day extract and 50/50\% diluted 30-day extract after 3-days for growth

Figure 4-2 Cell viability of human foreskin fibroblast cells when cultured in $65 \%$ and $85 \%$ 30-day extract after 7 days

Figure 4-3 Human foreskin fibroblast cells cultured for 72 hours in diluted and pure 30-day extract solutions from the MTS Assay

Figure 4-4 Percent cytotoxicity of human foreskin fibroblast cells seeded on $\mathrm{Mg}-\mathrm{Zn}$ and $\mathrm{Mg}-\mathrm{Zn}-\mathrm{Se}$ alloys measured by LDH quantification over a 3 day period of exposure

Figure 4-5 Scanning electron microscopy (secondary electron image) surface images of $\mathrm{Mg}-\mathrm{Zn}$ and $\mathrm{Mg}-\mathrm{Zn}-\mathrm{Se}$ before and after exposure to cell growth duration of 72 hours and precipitate formation from the degradation of the $\mathrm{Mg}-\mathrm{Zn}-\mathrm{Cu}$ alloy

Figure 4-6 Energy dispersive X-ray spectroscopy (EDS) analysis with backscatter detector SEM images of Mg-Zn (A), Mg-Zn-Se (B) surfaces, and precipitate formation of $\mathrm{Mg}-\mathrm{Zn}-\mathrm{Cu}(\mathrm{C})$ after cell growth for 72 hours

Figure 4-7 Scanning electron microscopy (SEM) images and X-ray photoelectron spectroscopy (XPS) analysis of oxide layer formation on the Mg-Zn-Se alloy

Figure 4-8 Scanning electron microscopy (SEM) images and X-ray photoelectron spectroscopy (XPS) analysis of oxide layer formation on the $\mathrm{Mg}-\mathrm{Zn}-\mathrm{Cu}$ alloy

Figure 5-1 Tafel plots (Potential vs. Current density) for the experimental magnesium alloys tested in a static Kokubo solution at $37^{\circ} \mathrm{C}$

Figure 5-2 Images of a ternary magnesium alloys before and after immersion in Kokubo's solution for 30 days

Figure 5-3 Changes in $\mathrm{pH}$ of Kokubo's solution with immersed magnesium alloys per day for 30 days 
Figure 5-4 Concentration of ions eluted from magnesium alloys measured by Inductively Coupled Plasma Mass Spectrometry (ICP-MS). A) Concentration of magnesium (II) ions, B) Concentration of selenium (IV) ions, C) Concentration of zinc (II) ions, D) Concentration of copper (II) ions, And E) Concentration of iron (II) ions. 


\section{CHAPTER 1 INTRODUCTION}

Aneurysmal subarachnoid hemorrhaging is a significant clinical concern, with an annual incidence rate of 6 to 12 individuals per 100,000 in western countries [1]. The prognosis for this disease once diagnosed indicates that $25-30 \%$ of patients will re-bleed and die within 1 month after initial hemorrhaging if no successful treatment is adopted, and $50 \%$ of survivors will die within 6 months without a successful treatment [2-3]. Elderly women ( $>51$ years of age) remain one of the largest demographics to experience subarachnoid hemorrhaging [4]. The elderly population grew at a rate of $2 \%$ per year from 12 million to 37 million, between 1950 and 2005, and it is expected to grow more rapidly than the general population until 2050 [5]. Clinically, elderly patients have a higher frequency of co-morbidities, rendering them unlikely candidates for successful conventionally invasive surgical procedures like basal aneurysm-clipping craniotomy. However, minimally invasive endovascular therapies such as stenting and coil embolization treatments generally represent a better-tolerated alternative than surgical clipping $[6,7]$.

Such minimally invasive endovascular techniques have been shown to be the most promising for patients who require medical treatment, as such techniques permit for minimal patient recovery time, and minimal surgical complications [8]. For aneurysmal coiling, which is a common therapy used to treat aneurysms by occluding the aneurysm body, platinum is the material of choice for manufacturing such coils because of its high corrosion resistance and biological/chemical inertness to caustic agents. However, due to its high cost and ambiguous long term histological evaluations, other potential 
biomaterials are currently being explored [9]. Such problems have substantially affected the clinical market, as high medical device costs have significantly increased the costs of surgical procedures, leaving patients unlikely to seek endovascular coiling therapy as a viable option for the treatment of neurovascular aneurysms. Another alternative endovascular medical device used to treat aneurysms includes stents. The use of intracranial stents is being more widely used as a therapeutic option to treat intra-cerebral aneurysms with an unfavorable geometry [10-15]. This technique includes the placement of a stent across the wide base or neck of an aneurysm, thus enabling the redirection of blood flow through the parent blood vessel [16]. Additionally, stenting applications for cerebral aneurysms have been widely described as a feasible means to recanalize acute symptoms of intracranial occlusions, which may be resulting complications of endovascular therapy [17-19]. Although stenting techniques have increased the treatment option for cerebral aneurysms, several risks exist which include the risk of stent misplacement, thromboembolic events, and in-stent stenosis or thrombosis [16].

Most endovascular stents currently available today are permanent and made from corrosion resistant metals such as stainless steel, Nitinol, and cobalt-chromium. Each stent material has a specific application for treating different clinical situations based on their specific properties. Stents are widely used because they can prevent or reduce the tendency for vessel restenosis, leading to shrinkage of the lumen, after an angioplasty [20]. Thus, careful selection must be made in materials used for stent manufacturing of a functional stent because such materials must possess favorable mechanical properties that can allow it to act as a scaffold while maintaining mechanical integrity to withstand the forces of the vessel wall. The main purpose of stent implants is to serve as a scaffold that 
can expand narrow vessels permitting the natural flow of fluids or bridge an area of arterial damage. However, the widely used permanent prosthetic devices have several unfavorable clinical shortcomings when implanted within the body that prevent them from being deemed as ideal devices. Some of these limitations include: long-term endothelial dysfunction, delayed re-endothelialization, thrombogenicity, permanent physical irritation, chronic inflammatory local reactions, mismatches in mechanical behavior between stented and non-stented vessel areas, inability to adapt to growth in young patients, and importantly non-permissive or disadvantageous characteristics for later surgical revascularization $[21,22]$.

Ideally, once a stent is implanted within a vessel, the walls of the stents start to become lined with endothelial cells preventing thrombosis, which after approximately 612 months arterial remodeling and healing is achieved [21]. After healthy arterial healing and remodeling has been achieved, there is no longer a functional need for the metallic stent. Realizing such an idea, the development of biodegradable stents that can degrade once the objectives of permanent stents have been fulfilled is currently being explored $[20,22-24]$. Although, there are very few metallic materials that can fulfill such physiological criteria; magnesium is one that possesses the ability to achieve such desired effects.

Magnesium alloys possess very selective mechanical properties which result in materials that are light, biodegradable and biocompatible [25-30]. An important aspect of these materials is their mechanical properties which are specifically important for different biomedical applications: such as cardiovascular stents or orthopedic devices. The high tensile yield strength and Young's modulus of magnesium based alloys yield to 
more favorable qualities for materials that are used for orthopedic and cardiovascular applications [27-29].



Figure 1-1. Comparison of mechanical properties for different stent materials. Logarithmic scale, MPa. Polymers: Poly-L-Lactide (PLLA); Polydiaxanone (PDS); Poly(glycolide-co-caprolactone)(PGACL) [27-29].

The mechanical properties of the materials currently being used to manufacture cardiovascular stents are compared in Figure 1-1. As seen, the material properties which are most indicative of vessel geometry adaptation are the elastic modulus, and tensile strength. Generally, the elastic (Young's) modulus of a material measures the resistance of a material to elastic deformation under an applied load. A stiff material (e.g., diamond) has a high Young's modulus and changes its shape only slightly under applied loads; while a flexible material (e.g., rubber) has a low Young's modulus and changes its shape considerably. Tensile strength is the stress a material can withstand when a load is applied. This value indicates the max value that a material can withstand without failure. As shown in Figure 1-1, the similarities between as-cast magnesium and other alloys and 
polymeric materials are directly compared. It can be seen that as-cast pure $\mathrm{Mg}$ is close in value to the Young's Modulus and tensile strength of Nitinol, which is a proven material that has shown to possess the appropriate mechanical properties for endovascular medical devices. Platinum also has both a higher Young's modulus and tensile strength than Nitinol, polymer materials, and magnesium; yet it retains the ability to be molded and shaped into different geometries common to the cardiovascular vessel network.

Polymeric based stents compete with conventional metallic based materials for the ideal endovascular medical device. However, the biodegradable polymers used to manufacture cardiovascular stents have led to several challenges that have yet to be overcome. Most of these polymers induce inflammatory changes during the absorption of polymeric degradation products, leading to severe intimal hyperplasia or thrombotic occlusion [31]. Polymeric materials like poly-L-lactic acid (PLLA) have been shown to have an acceptable biocompatibility and to adapt to the conformation of the vessel geometry. Another limitation is the inability of the stent to fully expand by balloon deployment and the need for the application of heat, which is of concern to normal vessel biology [32]. Recently polylactide based polymeric stents have been developed, but data is limited to animal testing and are not widely published [33]. 
Table 1-1. Bare Metal Stent Mechanical Properties [34]

Mechanical properties of stent materials

\begin{tabular}{|c|c|c|c|c|c|}
\hline Material & Composition, wt $\%$ & $\begin{array}{l}\text { Elastic } \\
\text { modulus, } \\
\text { GPa (Msi) }\end{array}$ & $\begin{array}{c}\text { Tensile } \\
\text { strength } \sigma_{v} \\
\text { MPa (ksi) }\end{array}$ & $\begin{array}{c}\text { Ultimate } \\
\text { tensile } \\
\text { strength } \sigma_{\text {udv }} \\
\text { MPa (ksi) } \\
\end{array}$ & $\begin{array}{c}\text { Elongation, } \\
\%\end{array}$ \\
\hline $\begin{array}{l}\text { 316L stainless steel, } \\
\text { annealed }\end{array}$ & $\begin{array}{l}17 \mathrm{Cr}, 12 \mathrm{Ni}, 2.5 \mathrm{Mo}, \\
<0.03 \mathrm{C} \text {, balance Fe" }\end{array}$ & $193^{b}(28)$ & $260^{\mathrm{a}}(38)$ & $550^{a}(80)$ & $50^{a}$ \\
\hline$\overline{\mathrm{Nitinol}^{\mathrm{c}}}$ & $55 \mathrm{Ni}-45 \mathrm{Ti}$ & $\begin{array}{c}\text { Austenite } \\
83(12), \\
\text { Martensite } \\
28 \text { to } 41 \\
\text { (4 to } 6)\end{array}$ & $\begin{array}{c}\text { Austenite } 195 \\
195 \text { to } 690 \\
\text { (28 to } 100) \\
\text { Martensite } \\
70 \text { to } 140 \\
\text { (10 to } 20)\end{array}$ & $\begin{array}{c}\text { Annealed } \\
(130) \\
\text { Work-hardened } \\
1900(276)\end{array}$ & $\begin{array}{c}\text { Annealed } \\
25 \text { to } 50, \\
\text { Work-hardened } \\
5 \text { to } 10\end{array}$ \\
\hline Tantalum $^{\mathrm{d}}$ & Commercially pure & $185(27)$ & $165(24)$ & $205(30)$ & 40 \\
\hline $\begin{array}{l}\text { Co-Cr-Mo alloy } \\
\text { (Elgiloy), } \\
\text { heat treated at } \\
525^{\circ} \mathrm{C} \text { for } 5 \text { hours }\end{array}$ & $\begin{array}{c}40 \mathrm{Co}, 20 \mathrm{Cr} \\
7 \mathrm{Mo}, 15.5 \mathrm{Ni}, \\
2 \mathrm{Mn}, 1 \mathrm{Be}, \\
0.15 \mathrm{C} \text {, balance Fe }\end{array}$ & $190(28)$ & $690(100)$ & $1020(148)$ & $>10$ \\
\hline Gold $^{\mathrm{d}}$, annealed & $\geq 99.99$ & 79.9 (11.6) & nil & $130(19)$ & 45 \\
\hline Gold $^{\mathrm{d}}, 60 \%$ reduction & $\geq 99.99$ & $79.3(11.5)$ & $205(30)$ & $220(32)$ & 4 \\
\hline Platinum, annealed & 99.95 & $164.6^{f}(23.9)$ & - & $\begin{array}{l}125 \text { to } 165 d \\
(18 \text { to } 241)\end{array}$ & 30 to $40^{d}$ \\
\hline
\end{tabular}

Table 1-2. Mechanical Properties of Polymeric Stents [36]

\begin{tabular}{lccr}
\hline Fiber & $\begin{array}{c}\text { Tensile } \\
\text { Strength }(\mathrm{MPa})\end{array}$ & $\begin{array}{c}\text { Modulus } \\
(\mathrm{MPa})\end{array}$ & $\begin{array}{r}\text { Strain } \\
(\%)\end{array}$ \\
\hline PLLA & 967 & 5,000 & 50 \\
PDS & 583 & 367 & 161 \\
PGACL & 721 & 477 & 151 \\
\hline
\end{tabular}


Table 1-3. Mechanical Properties of Magnesium Stents [21]

\begin{tabular}{|c|c|c|c|c|c|}
\hline Material & $\begin{array}{c}\text { Yield } \\
\text { Strength } \\
\text { (MPa) }\end{array}$ & $\begin{array}{c}\text { Tensile } \\
\text { Strength } \\
\text { (MPa) }\end{array}$ & $\begin{array}{c}\text { Elongation } \\
(\%)\end{array}$ & $\begin{array}{c}\text { In vitro } \\
\text { Degradation } \\
\text { Rate }\left(\mathrm{mm} \mathrm{y}^{-1}\right) \text { * }\end{array}$ & $\begin{array}{c}\text { Average } \\
\text { Grain Size } \\
(\mu \mathrm{m})\end{array}$ \\
\hline 316L SS: annealed (ASTM F138) & 190 & 490 & 40 & - & $12-30$ \\
\hline Pure $\mathrm{Mg}$ : as cast & 20 & 86 & 13 & 407 & - \\
\hline WE43 alloy: extruded T5 & 195 & 280 & 2 & 1.35 & 10 \\
\hline AM60B-F: die cast & - & 220 & $6-8$ & 8.97 & 25 \\
\hline ZW21: extruded & 200 & 270 & 17 & - & 4 \\
\hline WZ21: extruded & 140 & 250 & 20 & - & 7 \\
\hline
\end{tabular}

* The degradation rate is calculated from potentiodynamic polarization test.

Nitinol is an alloy widely used for bare metal stents and has an estimated elastic modulus of $83 \mathrm{GPa}$ (austenite phase) and a tensile strength of 195-690 MPa (austenite phase) and 28-41 GPa (martensite phase) and 70-140 MPa (martensite phase), respectively (Table 1-1) [34]. Comparing polymeric materials (Table 1-2), it can be seen that Nitinol has a much higher modulus than any of the available polymeric stents which are significantly more flexible. This is important to note, because despite the higher modulus of elasticity and lower tensile strengths, Nitinol still has the ability to conform to an-irregularly shaped vessel geometry. Comparatively, raw magnesium materials possess an elastic modulus of $45 \mathrm{GPa}$ which is very close in value to martensitic Nitinol [35]. Ascast magnesium also has a tensile strength of $86 \mathrm{MPa}$ which is also comparable to martensitic Nitinol, but forming processes can greatly increase these values as can be seen in Table 3.

In this work, it is proposed that the magnesium alloys are manufactured into a cardiovascular stent. The conventional process for manufacturing a stent is outlined in Figure 1-2. Although a typical process includes these steps, there is no standard manufacturing process that is used. Rather, the customizable process depends upon the 
performance expectations of the device as well as the properties of the alloys. It is proposed that the experimental magnesium alloys $\mathrm{Mg}-\mathrm{Zn}-\mathrm{Se}$ and $\mathrm{Mg}-\mathrm{Zn}-\mathrm{Cu}$ introduced in this dissertation may be manufactured using the process or a similar process outlined in Figure 1-2.

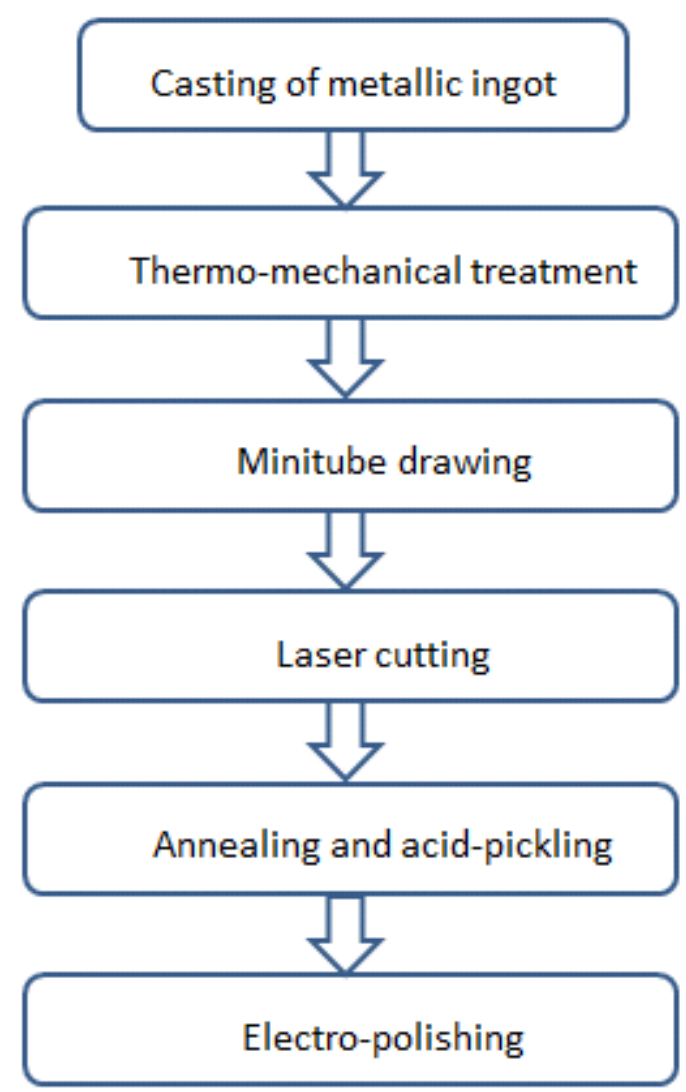

Figure 1-2. Fabrication process for cardiovascular stents [21].

\subsection{Problem of Inquiry and Research Focus}

After performing a comprehensive assessment of the materials currently available for the manufacturing of minimally invasive endovascular devices used for the treatment of cerebral aneurysms, there is no material (polymeric or metallic) that has a universal application in the manufacturing of such devices. Magnesium is one type of material that 
is used for the manufacturing of endovascular stents. However, there are several material properties of magnesium and its alloys which prevent its widespread use as a biomaterial, such as their uncontrollable degradation kinetics and poor mechanical properties. In an attempt to further the applicability of magnesium and its alloys for biomedical purposes, two novel magnesium alloys $\mathrm{Mg}-\mathrm{Zn}-\mathrm{Cu}$ and $\mathrm{Mg}-\mathrm{Zn}$-Se were created with the intention of improving upon the unfavorable qualities shown by similar magnesium based materials that have previously been explored.

\subsection{Aims and Objectives}

In order to assess the use of these experimental alloys for biomedical applications the most important factors are their mechanical properties, biocompatibility, and corrosion/degradation rate. In this thesis, these specific areas will be assessed.

Objective: The purpose of this researc is to assess the overall performance of these novel experimental magnesium alloys for endovascular medical device applications.

Specific Aim 1: To perform a comprehensive assessment of the mechanical properties of the as-cast experimental alloys $\mathrm{Mg}-\mathrm{Zn}-\mathrm{Cu}$ and $\mathrm{Mg}-\mathrm{Zn}-\mathrm{Se}$.

Expected Outcomes: It is expected that the new biodegradable magnesium alloys Mg-Zn$\mathrm{Cu}$ and $\mathrm{Mg}-\mathrm{Zn}-\mathrm{Se}$ will possess comparable mechanical properties to current as-cast magnesium alloys and metallic materials used to manufacture endovascular stenting devices. 
Specific Aim 2: To evaluating the biocompatibility of the as-cast $\mathrm{Mg}-\mathrm{Zn}-\mathrm{Cu}$ and $\mathrm{Mg}-\mathrm{Zn}-$ Se alloys through the use of in-vitro cellular studies.

Expected Outcomes: It is expected that the new biodegradable magnesium alloys Mg-Zn$\mathrm{Cu}$ and $\mathrm{Mg}-\mathrm{Zn}$-Se will demonstrate minimal cytotoxicity when performing the in-vitro cell studies.

Specific Aim 3: To profile the degradation kinetics of the as-cast $\mathrm{Mg}-\mathrm{Zn}-\mathrm{Cu}$ and $\mathrm{Mg}-\mathrm{Zn}-$ Se alloys through the use of electrochemical potentiodynamic polarization methods as well as gravimetric weight-loss methods.

Expected Outcomes: It is expected that the as-cast magnesium alloys $\mathrm{Mg}-\mathrm{Zn}-\mathrm{Cu}$ and $\mathrm{Mg}$ Zn-Se alloys will corrode at a rate necessary for vascular remodeling, which is a timeperiod within 3-6 months. 


\subsection{References}

1. Linn, F.H., Rinkel, G.J.E., Algra, A., VanGijn, J. Incidence of subarachnoid hemorrhage - role of region, year, and rate of computed tomography: A metaanalysis. Stroke. 1996; 27: 625-629.

2. Wermer, M.J.H., van der Scaaf, I.C., Velthuis, B.K., Algra, A., Buskens, E., Rinkel, G.J.E. Follow-up screening after subarachnoid hemorrhage: Frequency and determinants of new aneurysms and enlargements of existing aneurysms. Brain. 2005; 128: 2421-2429.

3. Alvord, EC., Loeser, J.D., Bailey, W.L., Copass, M.K. Subarachnoid hemorrhage due to ruptured aneurysms. A Simple method of estimating prognosis. Archives of Neurology. 1972; 27: 273-284.

4. Wolsteholme, J., Rivero-Arias, O., Gray, A., J. Molyneux A., S.C.Kerr, R., Yarnold, J., Sneade, M. International Subarachnoicd Aneurysm Trial (ISAT) Collaborative Group, 2007, Treatment Pathways, Resource Use, and Costs of Endovascular Coiling Versus Surgical Clipping After aSAH. Stroke: Journal of the American Heart Association. 2008; 39: 111-119.

5. Freid, V.M, Prager, K., MacKary, A.P., Xia, H., Chartbook on trends in the health of Americans. Health 2003, National Center for Health Statistics.

6. Molyneux, A., Kerr, R., Stratton, I. International Subarachnoid Aneurysm Trial (ISAT) Collaborative Group. International subarachnoid Aneurysms Trial (ISAT) of neurological clipping versus endovascular coiling in 2143 patients with ruptured intracranial aneurysms a randomized trial. Lancet. 2002; 360: 1267-1274.

7. Wieber, D.O., Whisnant, J.P., Huston, J.International Study of Unruptured Intracranial Aneurysms Investigators. Unruptured intracranial aneurysms: natural history, clinical outcome, and risks of surgical and endovascular treatment. Lancet. 2003; 362: 103-110.

8. Gonzalez, N., Susick, J., Duckwiler, G., Tateshima, S., Jahan, R., Martin, N., Vinuela, F. Endovascular Coiling of Intracranial Aneurysms in Elderly Patients: Report of 205 Treated Aneurysms. Neurosurgery. 2010; 66: 714-721.

9. Mori, K., Nakao, Y., Horinaka, N., Wada, R., Hirano, A., Maeda, M. Cerebral Aneurysms Regrowth and Coil Unraveling After Incomplete Guglielmi Detachable Coil Embolization: Serial Angiographical and Histological Findings. Neurolgia Medico Chirurfica. 2003; 43: 293-297. 
10. Akpek, S., Arat, A., Morsi, H., Klucznick, R.P., Strother, C.M., Mawad, M.E. Selfexpandable stent-assisted coiling of wide-necked in-tracranial aneurysms: a single-centre experience. American Journal of Neuroradiology. 2005; 26: 12231231.

11. Alfke, K., Straube, T., Dorner, L., Mehdorn, H.M., Jansen, O. Treatment of intracranial broad-neck aneurysms with a new self-expanding stent and coil embolization. American Journal of Neuroradiology. 2004; 25: 584-91.

12. Han, P.P., Albuquerque, F.C., Ponce, F.A., MacKay, C.L., Zabramski, J.M, Spetzler, R.F., McDougall, C.G. Percutaneous intracranial stent placement for aneurysms. Journal of Neurosurgery. 2003; 99: 23-30.

13. Lylyk, P., Ferrario, A., Pasbon, B., Miranda, C., Doroszuk, G. Buenos Aires experience with the Neuroform self-expanding stent for the treatment of intracranial aneurysms. Journal of Neurosurgery. 2005; 102: 235-41.

14. Biondi, A., Janardhan, V., Katz, J.M., Salvaggio, K., Riina, H.A., Gobin, Y.P. Neuroform stent-assisted coil embolization of wide-neck intracranial aneurysms: strategies in stent deployment and midterm follow-up. Neurosurgery. $2007 ; 61: 460-8$.

15. Howington, J.U., Hanel, R.A., Harrigan, M.R., Levy, E.I., Guterman, L.R., Hopkins, L.N. The Neuroform stent, the first micro-catheter-delivered stent for use in the intracranial circulation. Neurosurgery. 2004; 54: 2-5.

16. Mordasini, P., Walser, A., Gralla, F., Wiest, R., Ozobat, C., Reinert, M., Schroth, G. Stent placement in the endovascular treatment of intracranial aneurysms. Swiss Medical Weekly. 2008; 138: 646-654.

17. Levy, E.I., Mehta, R., Gupta, R., Hanel, R.A, Chamczuk, A.J., Fiorella, D., Woo, H.H., Albuquerque, F.C., Jovin, T.G., Horowitz, M.B., Hopkins, L.N. Selfexpanding stents for recanalization of acute cerebrovascular occlusions. American Journal of Neuroradiology. 2007; 28: 816-22.

18. Levy, E.I., Ecker, R.D., Horowitz, M.B., Gupta, R., Hanel, R.A., Sauvageau, E., Jovin, T.G., Guterman, L.R., Hopkins, L.N. Stent-assisted intracranial recanalisation for acute stroke: early results. Neurosurgery. 2006; 58: 458-63.

19. Gupta, R., Jovin, T.G., Tayal, A., Horowitz, M.B. Urgent stenting of the M2 (superior) division of the middle cerebral artery after systemic thrombolysis in acute stroke. American Journal of Neuroradiology. 2006; 27: 521-3.

20. Saito, S. New horizon of bioabsorbable stent. Catheter Cardiovascular Intervention. 2005; 66: 595-596. 
21. Moravej, M., Mantovani, M. Biodegradable metals for cardiovascular stent application: interest and new opportunities. International Journal of Molecular Science. 2011; 12: 4250-4270.

22. Erne, P. Schier, M. Resink, T.J. The road to bioabsorbable stents: reaching clinical reality? Cardiovascular Interventional Radiology. 2006; 29: 11-16.

23. Colombo, A., Karvouni, E. Biodegradable stents: -fulfilling the mission and stepping away. Circulation. 2000; 102: 371-373.

24. Peuster, M., Wohlsein, P., Brugmann, M., Ehlerding, M., Seidler, K., Fink, C., Brauer, H., Fischer, A., Hausdorf, G. A novel approach to temporary stenting: degradable cardiovascular stents produced from corrodible metal-results 6-18 months after implantation into New Zealand white rabbits. Heart. 2001; 86: 563569.

25. Heublein, B., Rohde, R., Kaese, V., Niemeyer, M., Hartung, W., Haverich, A. Biocorrosion of magnesium alloys: a new principle in cardiovascular implant technology? Heart. 2003; 89: 651-659.

26. Zartner, P., Cesnjevar, R., Singer, H., Weyand, M. First successful implantation of a biodegradable stent into the left pulmonary artery of a preterm baby. Catheter Cardiovascular Interview. 2005; 66: 590-594.

27. Witte, F., Kaese, V., Haferkamp, H., Switzer, E., Meyer-Linderberg, A., Wirth, C., Windhagen, $H$. In vivo corrosion of four magnesium alloys and the associated bone response. Biomaterials. 2005; 26: 3557-3563.

28. Witte, F., Fischer, J., Nellesen, J., Crostack, H., Kaese, V., Pisch, A., Beckmann, F., Windhagen, $H$. In vitro and in vivo corrosion measurements of magnesium alloys. Biomaterials. 2006; 27: 1013- 1018.

29. Staiger, M., Pietak, A., Huadmai, J., Dias, G. Magnesium and its alloys as orthopaedic biomaterials: a review. Biomaterials. 2006; 27: 1728-1734.

30. Li, L., Gao, J., Wang, Y. Evaluation of cyto-toxicity and corrosion behavior of alkaliheat-treated magnesium in simulated body fluid. Surface Coating. 2006; 185: 998.

31. Van der Giessen, W., Lincoff, A., Schwartz, R.S, van Beusekom, H.M., Serruys, P.W., Holmes, D.R., Ellis, S.G., Topol, E.J. Marked inflammatory sequelae to implantation of biodegradable and nonbiodegradable polymers in porcine coronary artery. Circulation. 1996; 94: 1690-1697. 
32. Tamai, H., Igaki, K., Kyo, E., Kosuga, K., Kawashima, A., Matsui, S., Komori, H., Tsuji, T., Motohara, S., Uehata, H. Initial and 6-month results of biodegradable poly-L-lactic acid coronary stents in humans. Circulation. 2000; 102: 399-404.

33. Vogt, F., Stein, A., Rettemeier, G., Krott, N., Hoffman, R., vom Dahl J., Bosserhoff, A.K., Michaeli, W., Hanrath, P., Weber, C., Blindt, R. Long term assessment of a novel biodegradable Paclitaxel-eluting coronary polylactide stent. European Heart Journal. 2004; 25: 1330-1340.

34. Levesque, J., Dube, D., Fiset, M., Mantovani, D. Materials and properties for coronary stents. Advanced Materials and Processes. 2004; 19: 45-49.

35. Avadesian, M.M., Baker, H. Magnesium and Magnesium Alloys; ASM International. Handbook Committee, 1999.

36. Zilberman, M., Nelson, K., Eberhart, R., Mechanical properties and In vitro degradation of bioresorbable fibers and expandable fiber-based stents. Journal of Biomedical Materials Research Part B: Application of Biomaterials Part B. 2005; 74: 792-799. 


\subsection{Introduction}

\section{CHAPTER 2 LITERATURE REVIEW}

Conventional implantable medical devices require the use of materials which have been experimentally proven to be corrosion resistant when placed within biological fluids such as saliva, blood and its constituents. However, with a necessity for next generation materials for medical applications, corrosive materials are being considered for applications where temporary medical device placement is desired. Such cases are commonly found in orthopedic and cardiovascular applications where temporary scaffolds for structural support are required, ultimately enhancing the wound healing and tissue regenerative process. A major line of biodegradable alloys for such purposes are those based upon a magnesium-zinc platform. These alloys have been composed in an array of assortments, and have been tailored for biomedical applications and nonbiomedical applications like energy storage [1]. For biomedical applications, selection of elemental compositions for the magnesium alloys should meet the requirements they be able to obtain a solid form, but more importantly they should yield corrosive by-products that have minimal negative effects on bodily function during the degradation process. Biomaterials comprised of minerals and trace elements already existing within the body are highly advantageous for such biodegradable applications. Polymeric materials are highly acclaimed for such biomedical applications due to their biocompatibility, degradation abilities and elastic compliance for cardiovascular applications; however, several mechanical and physical properties such as: loading failure in load bearing devices and post-implantation recoiling for cardiovascular applications are less when compared to that of metallic magnesium alloys $[2,3]$. 


\subsubsection{General Applications}

The ability of magnesium based materials to degrade has led to a multitude of medical applications. With years of research, current studies are now focused on the biological-biomaterial interaction and the cellular mechanisms as to how the magnesium materials are biologically influenced by the dissolution of corrosion byproducts from the bulk of the material $[2,9]$. Advanced studies are also exploring how polyaprolactone (PCL) and polylactic acid (PLA) polymer coatings influence the corrosion behavior and drug eluting kinetics for biodegradable stent applications [10]. Extensive studies on magnesium stents, including both animal studies and studies on human subjects, as well as topographical exploration through imaging techniques are well underway [9-14]. Orthopedic applications for magnesium materials have been shown to achieve enhanced bone response and excellent interfacial strength when implanted [15]. Magnesium materials have also been used for different types of fixation devices for orthopedic

surgery, such as screws, plates, and fasteners $[3,4,7,16]$. Recent studies have also shown that the implantation of a magnesium device shows minimal changes to blood composition within 6 months post-implantation without causing damage to excretory organs like the liver or the kidneys [17].

\subsection{Magnesium Alloys with Trace Elements}

\subsubsection{Material Structure}

There are several magnesium compositions which are currently being explored. Some of the alloys are at more developed research stages than others, and each alloy has been tailored for specific applications as previously mentioned. Pure magnesium has been used, as well as other elements including: zinc, manganese, aluminum, calcium, lithium, 
zirconium, yittrium and rare earth metals (RE) [1, 4, 6, 18-22]. Including these elements within the $\mathrm{Mg}$ matrix creates different mechanical and physical properties for the resulting alloy. If the alloying element can accomplish the metallurgical principle of forming a solid-solution, then solid solution strengthening can be achieved. A solidsolution forms when one two or more alloys are completely soluble in one another [23]. When viewing the solid solution formation under a microscope, only a single crystal lattice structure can be visualized rather than two different crystal structures, which would typically occur if the two metals are dissimilar and result in phase-separation. Solid solutions are generally stronger than pure metals, because of the enhanced crystal structure and the introduction of dislocations within the matrix, but generally have lower electrical conductivity when compared to that of pure metals [24]. This process is known as solid-solution strengthening. The formation of secondary phases improves the strength of the alloy, and is referred to as dispersion strengthening [24]. This is the common practice when forming an alloy. Typically, one metal will have larger atoms relative to other constituents within the material and form the primary phase called the matrix. The matrix consists of the major volume for the alloy. The second metal added to the alloy consists of smaller or larger atoms that are usually both stronger and harder. When the two metals are mixed together in the formation process, the resulting material is dispersion strengthened. Between the microstructure of two or more phases grain boundaries exist. When dispersion strengthening occurs, micro-scaled precipitates usually form within the grain boundaries, which further strengthen the material as the precipitates prevent slippage of the dislocations or defects within the grain or phase [23]. Such a treatment can be induced by a heat treatment within the manufacturing process that 
facilitates diffusion of specific elements that form conglomerates, and is referred to as precipitation hardening [23].

\subsubsection{Impurities within Magnesium}

Refined magnesium almost always has remnant amounts of other impurity elements. These impurities result from the natural composition of magnesium found within the earth, as well as the casting and refining processes used. The degree of impurities after the refining process is dependent upon the efficiency of the refining process itself. Elements currently found within the magnesium include: copper, beryllium, nickel, and iron [25]. Standards for characteristic element inclusion in Magnesium are: $4 \mathrm{ppm}$ beryllium, 100-300 ppm copper, 35-50 ppm iron, and 20-50 ppm nickel (weight percent) [25]. These elements may be intentionally added to the magnesium matrix, or other elements may be included, in which case they are referred to as general alloying elements [26]. The amount of these impurities should be controlled for all application, especially if pure magnesium is desired. Neglecting to remove the impurities from magnesium can cause detrimental implications once applied to a specific application, especially within the biomedical discipline. An example of such would be a magnesium stent with excessive amounts of nickel, which is known to be harmful to cells; nickel leaching within the body would produce toxic biological effects. Recent studies have further validated nickel's toxicity on human lung epithelial A594 cells [27].

\subsubsection{Impurities and Corrosion Effects}

The effect of impurities within the magnesium material for corrosion studies vary. In some instances the impurities may increase corrosion resistance, while in others the influence on corrosion may be difficult to determine as the behavior may be dependent on 
a number of other contributing factors. Such factors include the nature of the electrolyte media used for corrosion, the method of alloy preparation (cleaning techniques, heat treatments), whether or not surface treatments were performed, and the degree of imperfections within the material, amongst several other factors [28, 29]. These factors are extremely important when a magnesium based material is implanted within the body as it will undergo nearly continuous bio-corrosion for its entire lifespan while implanted. It has been well noted that iron, nickel, and copper are three critical corrosion elements, which when present within magnesium significantly increases the rate of corrosion [30]. These metals are harmful because of their low solid-solubility limits and because they serve as active cathodic sites within the material itself [31]. Cathodic sites are regions within the material where reduction reactions occur. These regions are essential to the formation of a corrosion cell, and are generally involved with absorbing electrons produced from oxidizing materials (anodic site). The corrosion rate at the cathode is reduced compared to the anode. The solid-solubility limit of a material is the extent to which an alloying element will dissolve in base materials without forming a different phase [32]. Generally, the higher the solid solubility limit the more likely the alloying element can homogenously disperse within a material. Whereas, low solid-solubility limits will more readily form separate phases within the material. For example, an alloy of magnesium-copper would more likely be separated into two different phases, a copper phase and a magnesium phase. This can be seen in classical cases of galvanic corrosion. Biologically, the presence of elements like iron, nickel, or copper within biomaterials serving as cathodic sites can have very influential effects, which may be positive or negative, depending upon the designer's intent for the material. Certainly two phases, 
which are regions of different elemental compositions will result, with a preferential dissolution of the anodic material while the mass of the cathodic material will remain. This can be beneficial if the remaining or leached materials can be utilized in enzymatic or metabolic reactions, otherwise they would be removed from the body by excretory organs like the kidneys, liver, and spleen [33].

\subsubsection{Magnesium and Corrosives}

Magnesium materials exposed to atmospheric conditions will develop a thin gray layer on its surface, which is partially protective [5]. Corrosion is promoted when magnesium is put in an environment containing chlorides or sulfates which may bind to the surface. If such chlorides or sulfates are localized, then pitting corrosion will likely occur [34].

For magnesium alloys, magnesium will always serve as the anode in aqueous environments because it has the lowest potential in a galvanic series. When the magnesium materials contain heavy metals like chlorides, copper, nickel, and iron, corrosion of the alloy is enhanced [5]. The ions from the aqueous solution plate onto the surface of magnesium (anodic site), forming active cathodic sites, which create a potential gradient between the two surfaces. The interaction between the dissimilar metals would essentially lead to galvanic corrosion on the surface of the magnesium due to the inhomogeneous surface composition and the electrolyte medium which propagates the movement of ions. Ions such as chlorides and oxidizing salts, in general, are considered to be corrosive if they have the ability to breakdown the protective layer on the surface of magnesium. Passivating elements like chromates, vanadates, and 
phosphates have been used to retard corrosion because of their ability to form a passive surface film [35-37].

\subsubsection{Magnesium and Humidity}

Magnesium is a metal that readily corrodes in the presence of water, as shown in equation (1). Atmospheric conditions contain certain levels of water content in the form of vapor, and the corrosion of magnesium alloys increases with relative humidity [5]. The corrosion of magnesium increases significantly when exposed to pure water [38]. Studies have shown that after 18 months of exposure to varying atmospheric conditions, neither pure magnesium nor any of its alloys exhibit evidence of surface corrosion at 9.5\% relative humidity $(\mathrm{RH})$, whereas some minimal corrosion occurs at $30 \% \mathrm{RH}$. At $80 \% \mathrm{RH}$, substantial surface corrosion occurs [38]. Therefore, when conducting corrosion experiments on magnesium or any of its alloys atmospheric humidity must be strictly controlled. This is especially true when evaluating the corrosion behavior of implantable medical devices manufactured from magnesium based materials.

\subsection{Alloying Elements}

There have been several different types of alloying elements used in magnesium based materials in an attempt to control their corrosion properties and determine their feasibility for material implanting. Elements like manganese, copper, aluminum, calcium, zirconium, gadolinium and zinc have all been explored [39].

\subsubsection{Manganese}

Manganese is primarily added to magnesium alloys to improve the corrosion resistance. This is achieved by reducing the harmful effects of impurities [40]. It has been shown that when manganese is added to magnesium, the corrosion contribution from the 
impurity of iron is rendered inactive because manganese atoms surround the iron atoms and act as local cathodes [41]. Manganese is also an essential biological trace mineral which serves in many roles within cellular systems, particularly as different cofactors for many metalloenzymes, such as oxidases and dehydrogenases, DNA and RNA polymerases, kinases, decarboxylases and sugar transferases [42, 43]. In humans, excessive amounts of Mn have been shown to induce "Manganism" which is a neurological disorder similar to Parkinson's disease [44].

\subsubsection{Copper}

The addition of copper has been shown to increase the strength of magnesium casts, but also to accelerate magnesium alloy corrosion rate in a sodium-chloride electrolyte medium [30]. In galvanic corrosion processes when two or more dissimilar metals are in contact, the more noble metal in the galvanic series will be preserved. For example, a $\mathrm{Mg} / \mathrm{Fe}$ alloy, magnesium is less noble (more negative voltage potential) than iron, and so it can be considered a sacrificial anode that will corrode more readily than iron. Copper has been shown to have many deleterious biological effects and in particular cellular cytotoxicity; however, it is an essential trace element in all living things [45]. Excessive copper amounts in the body have been linked to neurodegenerative diseases like Alzheimer's, Menkes, and Wilson disease [46]. A cohort study of 4035 men of age 30-60 years old, were used for a baseline study to assess the association between magnesium, zinc, and copper serum concentrations and all-cause, cancer, and cardiovascular disease mortality. Results revealed that serum levels with a) high copper, low magnesium, and b) concomitance of low zinc, with high copper or low magnesium increases the mortality risk for middle-aged men [47]. 


\subsubsection{Aluminum}

Alloys containing aluminum generally possess a high quality combination of mechanical properties, corrosion resistance, and die-castability [39]. It has been noted that aluminum tends to rapidly diffuse from the material matrix which contributes to creep deformation [39]. The poor creep resistance is substantial at temperatures above $125^{\circ} \mathrm{C}$ [48]. The normal operational temperature under biological conditions is $37 \pm 0.7$

${ }^{\circ} \mathrm{C}$ [49]. It is highly unlikely that substantial creep deformation is of immediate concern if aluminum-magnesium based alloys are used as biomedical implants. However, the tendency for aluminum to readily diffuse from the material matrix is of concern. Aluminum has a low density and is a passivating element, which lends to its corrosion resistance properties. Biologically, aluminum toxicity in the body has been shown to be detrimental to the body. In high doses, aluminum has been shown to cause neurotoxicity, with altered functions of the blood-brain-barrier [50]. Additionally, aluminum has been shown to increase estrogen-related gene expression in human breast cancer cells when cultured in a laboratory setting [51]. Aluminum has also been linked to Alzheimer's disease; however its implications as a causal factor are still ongoing [52]. Pathological results have shown that amyloid fibers or brain plaques in elderly patients contain enhanced amounts of aluminum [53].

\subsubsection{Zinc}

Zinc is commonly used as an alloying element for magnesium alloys, and the yield strength of magnesium alloys increase with its zinc content [54]. Magnesium alloys are especially important for orthopedic applications as it contains a Young's modulus with a value of 3-20 GPa, which is very similar to the Young's modulus for bone $20 \mathrm{GPa}$ [55]. 
One of the benefits of adding zinc to magnesium alloys is its effect of ebbing hydrogen gas produced by the magnesium alloys. One of the main challenges with using magnesium for orthopedic applications is that as magnesium corrodes/degrades in aqueous or liquid in environments, hydrogen gas evolution occurs, as shown in equation (1) in section 2.4.2 below. This is of major concern for orthopedic applications where the hydrogen gas accumulates and forms hydrogen gas pockets [56]. This is due to bone being poorly vascularized, with insufficient mechanisms to remove the excess hydrogen gas. Hydrogen gas evolution would be less of a concern in applications such as cardiovascular stents where the hydrogen gas could be removed from the implant site by convective transport phenomena. Hydrogen evolution and electrochemical impedance spectroscopy tests (EIS) reveal that in alloys with less zinc result in strong $\mathrm{H}_{2}$ gas evolution during degradation in simulated body fluids, whereas Zn-rich alloys hardly form any hydrogen gas [57]. It is believed that the presence of zinc in a magnesium alloy achieves such a process in two ways. The first is that the zinc ions in solution immediately around the bulk material are removed from solution, as shown in equation (7) in section 2.4.2 below. The zinc ions that are in solution further compete with the $\mathrm{Mg}^{+2}$ ions in solution for binding with free $\mathrm{OH}^{-}$anions forming $\mathrm{Zn}(\mathrm{OH})_{2}$, which ultimately reduce the amounts of free $\mathrm{H}_{2}$ gas.

Zinc is also an essential trace mineral to plants, animals, humans, and microorganisms $[58,59$, and 60$]$. It is essential to hundreds of biological enzymes, and transcription factors which are often coordinated with amino acids [61, 62]. If $\mathrm{Zn}$ is used as an alloying element in a biomedical implant, its dissolution from the bulk material due to corrosion when placed in vivo would be less detrimental than other elements like 
manganese, and aluminum, because zinc is readily absorbable through metabolic processes within cells. Excessive amounts of $\mathrm{Zn}$ have the potential to be corrosive in nature if ingested [63]. When zinc $\left(\mathrm{Zn}^{+2}\right)$ ions react with hydrochloric acid $(\mathrm{HCl}), \mathrm{Zn}-\mathrm{Cl}$ products are formed, which has been shown to damage parietal cells lining the stomach.

\subsection{Magnesium and its alloys- Corrosion Studies using Potentiodynamic and Electrical Impedance Spectroscopy}

The corrosive nature of biomaterials is very important to understand. It provides insight into how the material will behave once in situ, and it can estimate a material's biomimetic nature and at what rate a material will take to corrode/degrade. In order to simulate the biological environment a biomaterial will encounter once placed within a recipient, accelerated corrosion techniques using different simulated body fluids are used [64]. Corrosion studies using electrolyte media containing organic constituents is challenging. What is of interest is how the material corrodes in the presence of the organic containing medium, but more importantly how the organic medium interacts with the surface of the material during corrosion. There are two methods to evaluate the corrosion reactance of the material: weight by loss methodology or accelerated electrochemical processes [65].

\subsubsection{Negative Difference Effect}

Predicting the corrosion behavior of magnesium is very challenging, because it does not follow the normal corrosion behavior as other materials. Typically, anodic and cathodic reactions model the behavior of all electrochemical corrosion processes. The anodic and cathodic reactions are usually inversely related. As the applied potential $\left(\mathrm{E}_{\mathrm{appl}}\right)$ or current density increases, the anodic reaction rate increases and the cathodic 
reaction rate decreases. For example, an anodic increase of the applied potential causes an increase in the anodic dissolution rate, while the cathodic site decreases in hydrogen evolution [8].

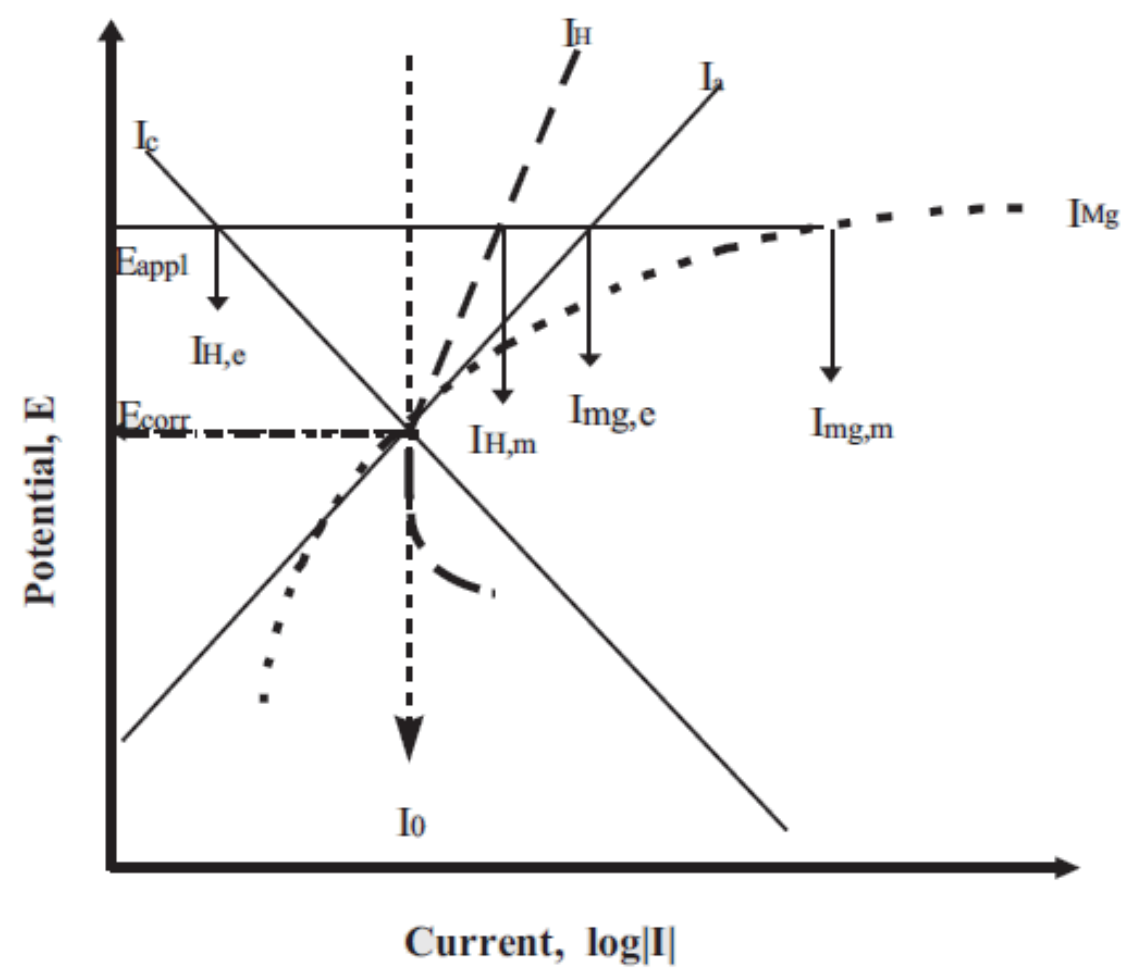

Figure 2-1. Tafel kinetic plot showing the negative difference effect (NDE) compared to normal predictive behavior expected for metals by Tafel theory [66].

Reprinted from Corrosion Science, 39 (5), G. Song, A. Atrens, D. Stjohn, J. Nairn, Y. Li, The electrochemical corrosion of pure magnesium in $1 \mathrm{~N} \mathrm{NaCl}, 21$, Copyright 1997, with permission from Elsevier.

As shown in Figure 2-1, for metals like zinc, copper, iron, and steel, normal anodic $\left(\mathrm{I}_{\mathrm{a}}\right)$ and cathodic $\left(\mathrm{I}_{\mathrm{c}}\right)$ partial reactions are marked, which are consistent with Tafel theory. According to such theory, the rates of these two partial reactions are equal at the corrosion potential $\left(\mathrm{E}_{\mathrm{corr}}\right)$. Normally, positively increasing the applied potential $\left(\mathrm{E}_{\mathrm{appl}}\right)$, would cause a shift in anodic potential ( $\mathrm{I}_{\mathrm{a}}$ ) to $\mathrm{I}_{\mathrm{MG}, \mathrm{e}}$ while the cathodic potential would 
decrease along the curve $I_{c}$ to $I_{H, e}$. However, this is certainly not the case for magnesium based alloys. For magnesium alloys, a positive increase in the applied potential $\left(E_{\text {appl }}\right)$ causes an increase in both the anodic partial potential and the cathodic partial reaction, represented by dashed lines $\mathrm{I}_{\mathrm{H}}$ and $\mathrm{I}_{\mathrm{Mg}}$, respectively. This is the most important feature of the Negative Difference Effect (NDE) which magnesium alloys experience.

\subsubsection{Magnesium Corrosion: Oxidation-Reduction}

Magnesium alloys corrode/degrade in aqueous materials by several different oxidation-reduction reactions which are influenced by the alloying elements. Generally, the corrosion of magnesium in water will yield magnesium-hydroxide and hydrogen gas. The following net reaction (1) from half-cell reactions are given below:

$$
\mathrm{Mg}(\mathrm{s})+2 \mathrm{H}_{2} \mathrm{O}(\mathrm{aq}) \longrightarrow \mathrm{Mg}(\mathrm{OH})_{2}(\mathrm{~s})+\mathrm{H}_{2}(\mathrm{~g})
$$

Contributing Half-cell reactions:

$$
\begin{aligned}
& \mathrm{Mg}(\mathrm{s}) \longrightarrow \mathrm{Mg}^{2+}(\mathrm{aq})+2 \mathrm{e}^{-} \text {[Oxidation Reaction] } \\
& 2 \mathrm{H}_{2} \mathrm{O}(\mathrm{aq})+2 \mathrm{e}^{-} \longrightarrow \mathrm{H}_{2}(\mathrm{~g})+2 \mathrm{OH}^{-}(\mathrm{aq}) \text { [Reduction Reaction] } \\
& \mathrm{Mg}^{2+}(\mathrm{aq})+2 \mathrm{OH}^{-} \longrightarrow \mathrm{Mg}(\mathrm{OH})_{2} \text { (s) [Byproduct Formation] }
\end{aligned}
$$

Typically, zinc is used as an alloying element, as it also possesses the ability to displace hydrogen ions from solution. If zinc is used, as in magnesium-zinc alloys, then the following reactions would occur in addition to those mentioned above:

$$
\begin{aligned}
& \mathrm{Zn}(\mathrm{s})+2 \mathrm{H}_{2} \mathrm{O}(\mathrm{aq}) \longrightarrow \mathrm{Zn}(\mathrm{OH})_{2}(\mathrm{~s})+\mathrm{H}_{2}(\mathrm{~g}) \\
& \mathrm{Zn}(\mathrm{s}) \longrightarrow \mathrm{Zn}^{2+}(\mathrm{aq})+2 \mathrm{e}^{-} \text {[Oxidation Reaction] }
\end{aligned}
$$

Magnesium Metal can also remove zinc ions from solution:

$$
\mathrm{Mg}(\mathrm{s})+\mathrm{Zn}^{2+}(\mathrm{aq}) \longrightarrow \mathrm{Zn}(\mathrm{s})+\mathrm{Mg}^{2+}(\mathrm{aq})
$$


As seen from these equations, magnesium reactions with aqueous solutions produce hydrogen gas. This is a problem if the material is used in orthopedic applications where vascularization and fluid transport are minimal, thus resulting in the formation of potentially harmful hydrogen pockets. Experimentation has shown that the addition of zinc has the ability to significantly decrease the amount of hydrogen gas evolved, when measured by electrical corrosion testing [4].



Figure 2-2. Microphotograph of the magnesium surface after performing polarization analysis in $\mathrm{NaCl}$ solution (50x).

Reprinted from Materials Research, 10 (1), Wolf Dieter Müller; Maria Lucia Nascimento; Miriam Zeddies; Mariana Córsico; Liliana Mabel Gassa; Mónica Alicia Fernández Lorenzo de Mele, Magnesium and its alloys as degradable biomaterials. Corrosion studies using potentiodynamic and EIS electrochemical techniques, 2007, with permission from Creative Commons Licensing 3.0.

Corrosion is a surface effect, and the medium in which the material is placed greatly influences the parameters and degree to which the corrosion occurs. It has been noted that the corrosion of magnesium in water forms a hydroxide $\left(\mathrm{OH}^{-}\right)$layer on the surface of the 
material. If the corrosive medium contains any chlorides with concentrations above 30 $\mathrm{mmol} / \mathrm{L}$, the hydroxide will be converted to magnesium chloride $\left(\mathrm{MgCl}_{2}\right)$ rather than magnesium hydroxide [5]. In the case of biological fluids where chloride concentrations are approximately $150 \mathrm{mmol} / \mathrm{L}$, surface pitting corrosion is observed as seen in Figure 22 [6]. Ultimately, the types of corrosion that are evidenced on the surface of the material are dependent upon the electrolytic medium in which the corrosion of the material is taking place $[7,8]$.

\subsubsection{Magnesium Corrosion Mechanisms}

The corrosion behavior of magnesium involves different processes attributed to the NDE. Several different theories have been proposed to explain the entire corrosion system magnesium experiences. However, most models proposed do not universally explain all of the corrosion behaviors experienced and observed. Figure 3.a.I and 3.a.II represent a model explaining the formation of a Partially Protective Surface Film. Naturally, thin passivating films form on the surface of magnesium which protects it from further corrosion [5]. 


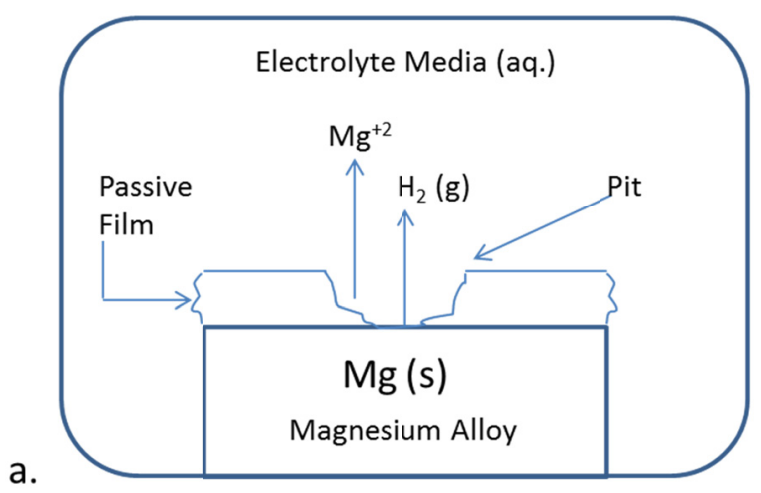

I. Low Applied Potential (E) or Current (I)

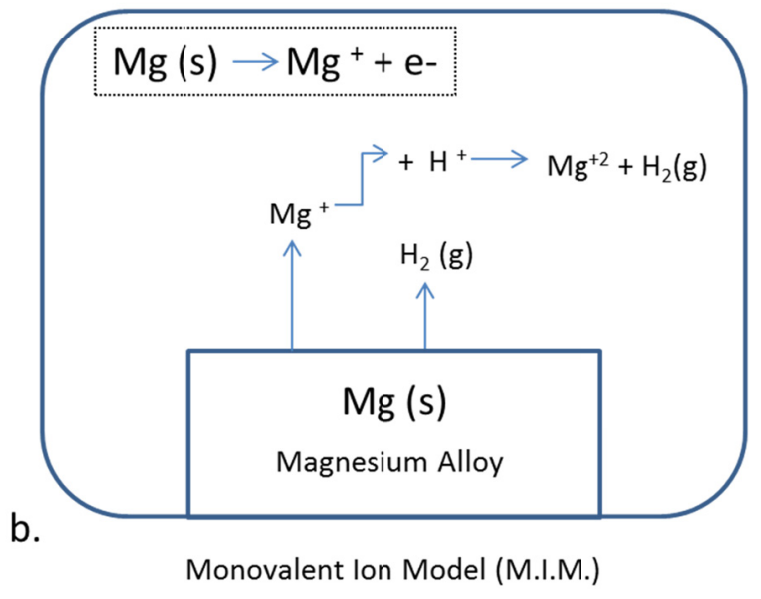

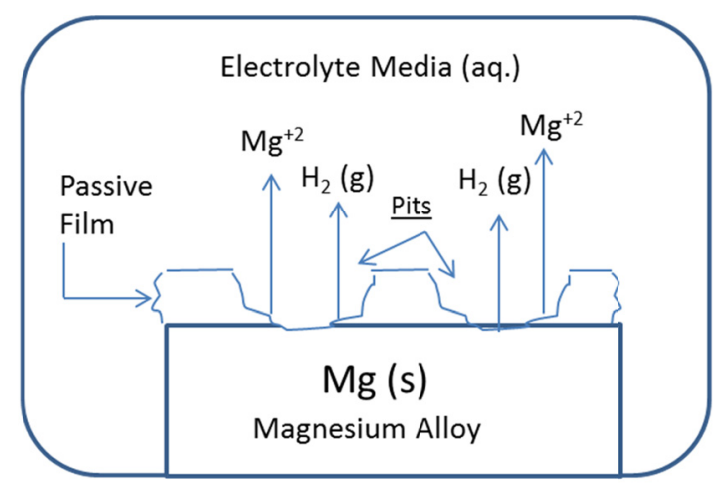

II. High Applied Potential (E) or Current (I)

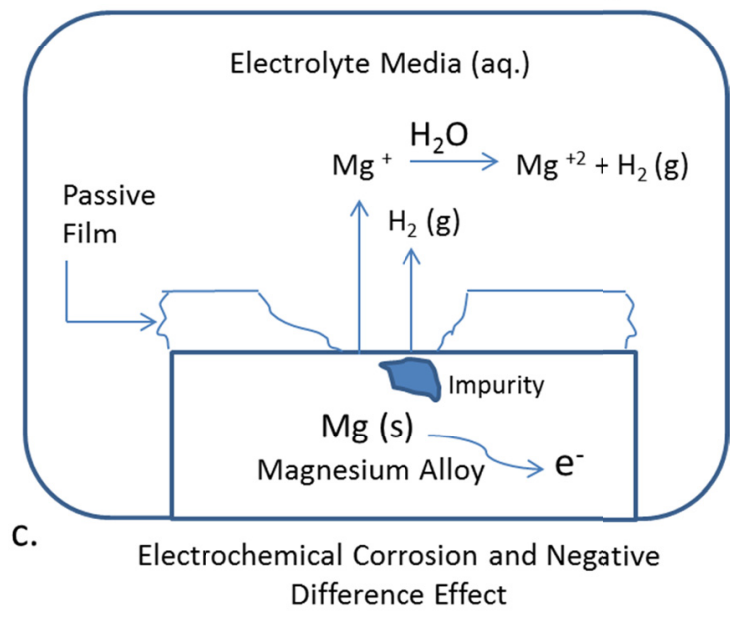

Figure 2-3. Schematic Illustrating different corrosion mechanisms for Magnesium. a (I) $\mathrm{Mg}^{+2}$ and $\mathrm{H}_{2}$ (g) evolution under low $\mathrm{E}$ or I. a(II) $-\mathrm{Mg}^{+2}$ and $\mathrm{H}_{2}$ (g) evolution at high $\mathrm{E}$ or I, with multiple pit formation. b. Monovalent Ion Model. c. Negative Difference Effect (NDE) and $\mathrm{Mg}^{+2}$ and $\mathrm{H}_{2}$ (g) evolution during accelerated electrochemical corrosion testing. Guang Ling Song and Andrej Atrens: Corrosion Mechanisms of Magnesium Alloys. Advanced Engineering Materials. 1999. 1. 11-33. Copyright Wiley-VCH Verlag GmbH \& Co. KGaA. Reproduced with permission.

This model shows that the NDE is responsible for the breakdown of the thin protective film when current is flowing through the interfacial electrical double layer formed between the magnesium surface and the electrolytic medium. This leads to divalent ions being released from the magnesium surface through oxidation, further releasing it into the corroding medium. At low applied voltages or current density, less 
localized corrosion pitting is evident (Figure 3.a.I), as compared to higher voltages or current density values, where more pit formation occurs (Figure 3.a.II). The hydrolysis of magnesium will lower the $\mathrm{pH}$ and increase the parasitic corrosion rate [67]. This model was questioned as to the protective nature of the film formation, however, recent research investigating the corrosion behavior of AZ91 magnesium alloy shows that corrosion products $\mathrm{Mg}_{5}\left(\mathrm{CO}_{3}\right)_{4}(\mathrm{OH})_{2} .8 \mathrm{H}_{2} \mathrm{O}$ and $\mathrm{MgO}$ form a passive film on the surface of the material retarding further corrosion [68].

Another model proposing the NDE on the corrosion behavior of magnesium is the monovalent ion model (Figure 3.b). This model proposes that a transient $\mathrm{Mg}^{+}$monovalent ion is evolved by the reaction:

$$
\mathrm{Mg}(\mathrm{s}) \rightarrow \mathrm{Mg}^{+}+\mathrm{e}^{-} \text {[Oxidizing Reaction] }
$$

The $\mathrm{Mg}^{+}$would then chemically react with two protons to yield hydrogen gas via:

$$
2 \mathrm{Mg}^{+}+2 \mathrm{H}^{+} \longrightarrow 2 \mathrm{Mg}^{2+}+\mathrm{H}_{2}(\mathrm{~g})
$$

Song and Atrens notably identify that this monovalent ion model (M.I.M.) falls short of explaining how the magnesium dissolution rate can drop down to near zero at a potential approximately $1000 \mathrm{mV}$ higher than $\mathrm{Mg}^{+} / \mathrm{Mg}_{\text {eqm }}$ potentials [66].

\subsubsection{Electrochemical Corrosion Model}

One of the most coherent magnesium corrosion models is proposed by Song et al., as shown in Figure 3c. This model combines the M.I.M. with the protective film model as discussed above, to provide a model that addresses the shortcomings of other models, while accounting for the NDE and the electrochemical processes [69]. This model introduces the idea that with an increasing applied potential or current density, more area on the surface of the material becomes film free. In the film-free areas, magnesium 
corrosion produces the monovalent $\mathrm{Mg}^{+}$ion (8), which can still react with water to produce hydrogen gas:

$$
\mathrm{Mg}^{+}+2 \mathrm{H}_{2} \mathrm{O} \longrightarrow \mathrm{Mg}^{+}+2 \mathrm{OH}^{-}+\mathrm{H}_{2}(\mathrm{~g})
$$

This model proposes that with an applied potential or current density that is negative, the surface film should be intact [69]. This essentially means that the velocity of the current density is in the opposite direction of the electron flow. Because the entire surface is covered with a naturally forming oxide film, the oxidation of magnesium is very low. This addresses the protective nature of the film formation. This model still permits cathodic hydrogen evolution to occur at a negative potential, which would decrease with increasing potential until a pitting potential is reached [69]. Such pitting or localized corrosion would break down the protective layer, allowing for more hydrogen evolution and magnesium ions to be released into solution from the now film-free region. As the potential or current density continues to increase, more hydrogen evolution would occur which is supported by the M.I.M., and fulfills the first condition of the NDE. The anodic dissolution of magnesium (8) shows that only one electron is involved in the reaction. Meaning, if the current density were to be held constant, more magnesium would be dissolved into aqueous solution. This is the second condition expressed by the NDE. Hence, this is one of the few complete models accounting for the NDE, while logically piecing together the other chemical and electrochemical tendencies.

\subsubsection{Non-Electrochemical Testing Methodology}

When evaluating corrosion characterization using organic media, weight by loss methodology is the safest technique as there is no applied electrical voltage to accelerate the corrosion process; however, this requires longer exposure times to evaluate and 
characterize corrosion reactions and rates [70]. Alternative methods include accelerated corrosion methods using electrochemical methods that primarily serve to maintain a constant potential difference between the working electrode (specimen) and a counterelectrode [71].

\subsubsection{Electrochemical Testing Methodology}

Two important electrochemical corrosion techniques for the analysis of magnesium are: cyclic potentiodynamic polarization and electrical impedance spectroscopy. Cyclic polarization theory is based upon the concept that the material's steady state corrosion rate can be changed by varying the applied voltage and observing a change in current density. The corrosion behavior of a material is commonly illustrated with cyclic polarization curves of potential versus logarithmic current density [72]. Analysis of such cyclic polarization curves can provide information pertinent for biological implants such as pitting potential $\left(E_{P}\right)$, breaking potential $\left(E_{B}\right)$, hysteresis, terminating current density $\left(\mathrm{i}_{\mathrm{T}}\right)$, and corrosion rate. In generating cyclic polarization curves, measurements begin below the rest potential $\left(\mathrm{E}_{\mathrm{r}}\right)$ or open circuit potential $\left(\mathrm{E}_{\mathrm{OCP}}\right)$ or corrosion potential $\left(\mathrm{E}_{\mathrm{corr}}\right)$ value, and forward scans in a positive direction past the breaking potential $\left(\mathrm{E}_{\mathrm{B}}\right)$ until the potential reaches the preset vertex potential or vertex current. At this point, the scan reverses to some endpoint, which is either the original $\mathrm{E}_{\text {corr }}$ value or a value below $\mathrm{E}_{\text {corr }}$. If a hysteresis loop forms from the downward scan from point $E_{B}$ to the endpoint, the material is susceptible to localized corrosion; the larger the loop, the more susceptible the material to localized corrosion [73]. If no hysteresis loop is generated, then the material is not susceptible to localized corrosion and it is quite possible that a uniform passive film could be protecting the surface, which could be removed from corrosion, thus resulting in 
uniform or localized corrosion. Similar information can be obtained by analyzing Tafel Kinetics plots which plot current density vs. voltage. These plots reveal the passive and corrosion currents $\left(\mathrm{i}_{\mathrm{p}} \mathrm{i}_{\text {corr }}\right)$, and the breakdown and corrosion potentials $\left(\mathrm{E}_{\mathrm{bd}}, \mathrm{E}_{\text {corr }}\right)$. Mueller et al., has successfully shown that the presence of organic contents in the electrolyte medium used for corrosion significantly influences these parameters as shown in Figure 2-4.

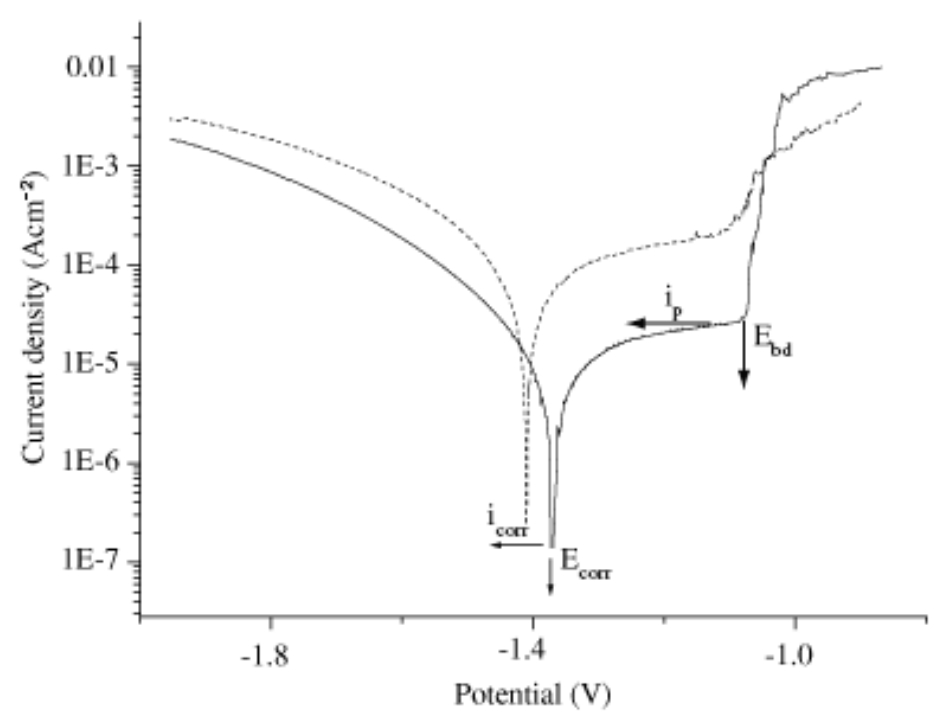

Figure 2-4. Log i versus potential polarization curve made for AZ31 alloy in phosphate buffer saline $+0.1 \mathrm{~g} / \mathrm{L}$ albumin. Passive and corrosion currents $\left(i_{p}, i_{\text {corr }}\right)$, the breakdown and corrosion potentials $\left(\mathrm{E}_{\mathrm{bd}}, \mathrm{E}_{\mathrm{corr}}\right)$ are indicated. Dashed line corresponds to the control polarization curve made in phosphate buffer saline without protein Albumin.

Reprinted from Materials Research, 10 (1), Wolf Dieter Müller; Maria Lucia Nascimento; Miriam Zeddies; Mariana Córsico; Liliana Mabel Gassa; Mónica Alicia Fernández Lorenzo de Mele, Magnesium and its alloys as degradable biomaterials. Corrosion studies using potentiodynamic and EIS electrochemical techniques, 2007, with permission from Creative Commons Licensing 3.0.

Electrical impedance spectroscopy (E.I.S.) is also an important technique requiring a more complex interpretation from the results, but also avails important information 
about the degradation/corrosion rate of a material which is governed by kinetics and thermodynamics [74]. Researchers in Germany have successfully demonstrated that electrochemical corrosion techniques using E.I.S. and cyclic polarization can be used to evaluate the corrosion behavior of material in organic electrolyte media with protein albumin which significantly contributes to differences in corrosion behavior [75]. Albumin is a major protein found within blood plasma with cations, including $\mathrm{Ca}^{+2}, \mathrm{Na}^{+}$, $\mathrm{K}^{+}$. Evaluating corrosion behavior with protein albumin is biologically relevant because most of the clotting factors found within whole blood are found within plasma [76]. When an implant comes into contact with blood, proteins like thrombin adsorb onto its surface leading to clinical complications like thrombosis.

\subsubsection{Cyclic Polarization and Electrical Impedance Spectroscopy Experiments in Organic Electrolyte Media}

In a study by Mueller et. al, corrosion studies were conducted on a test sample of AZ31 (Mg-Zn) alloy in different $\mathrm{NaCl}$ concentrations $(0.1 \%$ and $1 \%)$ and a phosphate buffer saline (PBS) medium with protein albumin [75]. Based upon the current density $\left(A \cdot \mathrm{cm}^{-2}\right)$ vs. potential curves $(\mathrm{V})$, it is evident that there are regions of passive formations at voltages around $-1.7 \mathrm{~V}$ for all alloy samples regardless of the electrolytic medium.

Current density vs. potential curves reveal that the passivation region continues until the breakdown potential $\left(\mathrm{E}_{\mathrm{bd}}\right)$ at about $-1.1 \mathrm{~V}$ [75]. Scanning electron microscope images of the surface reveal that localized pitting corrosion is characteristic, which was documented to begin at $\mathrm{E}_{\mathrm{bd}}[75]$. It has also been shown that "cracks" developed on the surface of the alloy, which can be attributed to hydrogen evolution. A mechanism by which this occurs is that hydrogen adsorbs onto the surface at points of defects within the material, where 
surface stress is high [77]. Once a crack is generated, hydrogen will be initiated within the cracked region at the site of high stress and the electrolytic solution then comes into contact with the inside of the crack [78]. This can further the corrosion process. Another very important surface attribute which could accelerate corrosion is surface roughness. Surface roughness for biomaterials is particularly important when considering applications where the material serves in flow systems, as it substantially contributes to corrosion behavior [79]. Flow accelerated corrosion typically increases surface roughness, and as a result of increased surface roughness, corrosion rate increases with time [80]. It has also been characterized that the presence of protein albumin in PBS reduces Passive $\left(\mathrm{i}_{\mathrm{p}}\right)$ and Corrosion $\left(\mathrm{i}_{\text {corr }}\right)$ currents when compared to values where corrosion experiments were conducted in PBS alone [75]. This phenomenon can most likely be attributed to protein adsorption [81, 82]. Electrical Impedance Spectroscopy results further support that chloride ions favor the metal dissolution, while the presence of phosphate ions and protein in electrolytic media reduces the corrosion attack [75].

\subsection{Conclusions and Suggested Research}

In this literature review, the current progress of research for magnesium alloys has been presented and discussed. The biological implication of alloying elements included in a bulk magnesium material, as well as a theoretical proposal for possible corrosion byproduct formation of magnesium metals is presented. Research efforts have concentrated on both mechanical and material properties; however clinical needs and materialcellular/protein studies are needed. Magnesium based alloys show a tendency for biocompatibility, and materials for specific medical applications should be developed, especially for cardiovascular applications where hydrogen evolution is less problematic 
as compared to orthopedic applications. Corrosion behavior characterization with more in situ experimental parameters is particularly desirable. Biomedical research expertise is required to translate the wealth of biomedical research data into an understanding of how these materials will behave within patients.

\subsection{References}

1. Pollock, T., Weight Loss with Magnesium Alloys, Science May 2010; 328: 986-987.

2. Bonan, R., Asgar, A. Biodegradable Stents-Where are we in 2009, US Cardiology. 2009; 6: 81-84.

3. Staiger M., Pietak, A., Huadamai, J., Dias, G., Magnesium and its Alloys as Orthopedic Biomaterials: a review. Biomaterials. 2006; 27: 1728-1734.

4. Witte, F., Fischer, J., Nellesen, J, Crostack, H., Kaese, V., Pisch, A., Beckmann, F., Windhagen, H., In Vitro and In Vivo Corrosion Measurements of Magnesium Alloys, Biomaterials. 2006; 27: 1013-1018.

5. Saw, BA., Corrosion Resistance of Magnesium Alloys, ASM Handbook 2003;13

6. Song, G., Control of Biodegradation and Biocompatible Magnesium Alloys, Corrosion Science. 2007; 49: 1696-1701.

7. Witte, F., Kaese V., Haferkamp, H., Switzer, E., Meyer-Lindenberg, A., Wirth, C.J., Windhagen, H. In Vivo Corrosion of Four Magnesium Alloys and the Associated Bone Response, Biomaterials. 2005; 26: 3557-3563.

8. Song, GL., Atrens, A., Corrosion Mechanisms of Magnesium Alloys. Advanced Engineering Materials. 1999; 1: 11-13.

9. Hueblein, B., Rohde, R., Kaese, V., et al., Biocorrosion of Magnesium Alloys: A New Principle in Cardiovascular Implant Technology, Heart. 2003; 89: 651656.

10. Chen, Y., Song, Y., Zhang, S., Li, J., Zhao, C., Zhang, X., Interaction Between a High Purity Magnesium Surface and PCL and PLA Coatings During Dynamic Degradation, Biomedical Materials. 2011; 6: 1-8. 
11. Waksman, R., Pakala, R., Kuchulakanti, P.K., Baffour, R., Hellinga, D., Seabron, R., Tio, F.O., Wittchow, E., Hartwig, S., Harder, C., Rohde, R., Heublein, B., Andreae, A., Waldmann, K.H., Haverich, A. Safety and Efficacy of Bioasborbable Magnesium Alloy Stents in Porcine Coronary Arteries. Catheterization and Cardiovascular Interventions. 2006; 68: 607-617.

12. Maeng, M., Jensen, L.O., Falk, E., Andersen, HR., Thuesen, L., Negative Vascular Remodeling After Implantation of Bioabsorbable Magnesium Alloy Stents in Porcine Arteries: A Randomized Comparison with Bare-Metal Stent and Sirolimus-Eluting Stents. Heart. 2009; 95: 241-246.

13. Waksman, R., Erbel, R., Di Mario C., Bartunek, J., de Bruyne, et al. Early and LongTerm Intravascular Ultrasound and Angiographic Findings After Bioabsorbable Magnesium Stent Implantation in Human Coronary Arteries. JACCC Cardiovascular Intervention. 2009; 4: 312-320.

14. Erbel, R., Di MC., Bartunek, J., Bonnier, J., et al. Temporary Scaffolding of Coronary Arteries with Bioabsorbable Magnesium Stents: A Prospective Non-Randomized Multi-Center Trial. Lancet. 2007; 369: 1869-1875.

15. Castellani, C., Lindtner, RA., Hausbrandt, P, Tschegg, E., Stanzl-Tschegg, SE, Zanoni, G., Beck, S., Weinberg, AM., Bone-Implant Interface Strength and Osseointegration: Biodegradable Magnesium Alloys Versus Standard Titanium Control. Acta Biomaterialia. 2011; 1: 432-440.

16. Zhang, GD., Huang, JJ., Yang, K., Zhang, BC., Ai, HJ., Experimental Study of In Vivo Implantation of Magnesium Alloy at Early Stage. Acta Metallurgica Sinica. 2007; 43: 1186-1190.

17. Zhang, E., Xu, L., Yu, G., Pan, F., Yang, K., In Vivo Evaluation of Biodegradable Magnesium Alloy Bone Implant in the First 6 Months Implantation. Journal of Biomedical Material Research: Part A. 2009; 90: 882-893.

18. Wang, HX., Guan, SK., Wang, X., Ren, CX., Wang, LG., In Vitro Degradation and Mechanical Integrity of $\mathrm{Mg}-\mathrm{Zn}-\mathrm{Ca}$ Alloy Coated with Ca-Deficient Hydroxyapetite by the Pulse Electrodeposition Process. Acta Biomaterialia. 2010; 6: 1743-1748.

19. Zhang, J., Pan, F., Guo, Z., Development of a T-Type Mg-Zn-Al Alloy: An Investigation of the Microstructure and Solidification Characteristics. Materials Science Forum. 2007; 123: 546-549.

20. Lin, L, Wang, F., Yang, L., Chen, L., Zheng, L., Solute Pre-Precipitation and Phase Transformation in a Mg-Zn-Gd Alloy. Advanced Materials Research. 2010; 152153: 864-867. 
21. Huan, ZG., Leeflang, MA., Zhou, J., Fratila-Apatichei, LE., Duszczyk, J., In Vitro Degradation Behavior and Cytocompatibility of Mg-Zn-Zr Alloys. Journal of Material Science: Materials in Medicine. 2010; 9: 2623-2635.

22. Wang, J., Wang, L., Guan, S., Zhu., S., Ren, C., Hou, S., Microstructure and Corrosion Properties of as Sub-Rapid Solidification Mg-Zn-Y-Nd Alloy in Dynamic Simulated Body Fluid for Vascular Stent Application. Journal of Material Science: Materials in Medicine. 2010; 7: 2001-2008.

23. Callister Jr., William D. 2006. Materials Science and Engineering: An Introduction, 7th Edition. John Wiley \& Sons.

24. Askeland, D., Phule, P., 2006. The Science and Engineering of Materials. Cengage Learning, $5^{\text {th }}$ Edition. Thomson.

25. Witte, F., Hort, N., Vogt, C., Cohen, S., Kainer, K., Willumeit, R., Feyerabend, F., Degradable Biomaterials Based on Magnesium. Current Opinion in Solid State and Material Science. 2008; 12: 63-72.

26. Revie R. Ulig's Corrosion Handbook. 2000. $2^{\text {nd }}$ Edition. NY, USA: John Wiley \& Sons.

27. Ahamed, M., Toxic Response of Nickel Nanoparticles in Human Lung Epithelial A549 Cells. Toxicology In Vivo. 2011.

28. Viswanadham, P., Singh, P., Failure Modes and Mechanisms in Electronic Packages. 1998. NY, US A: Chapman \& Hall.

29. R. W. Murray, J. E. Hillis, Magnesium Finishing: Chemical Treatment and Coating Practices, SAE Technical Paper Series \#900 791, Detroit 1990.

30. J. E. Hillis, R. W. Murray, Finishing Alternatives for High Purity Magnesium Alloys, SDCE 14th International Die Casting Congress and Exposition, Toronto 1987, Paper No. G-T87-003.

31. A. L. Olsen, Corrosion Characteristics of New Magnesium Alloys, Translation of Paper presented at the Bauteil'91, DVM Berlin 1991: 1-21.

32. Hill, J., Petrucci, H., General Chemistry: An Integrated Approach. 1999. $2^{\text {nd }}$ edition. Upper Saddle River, NJ: Prentice Hall.

33. Tortora, G., Grabkowski, S., Principles of Anatomy and Physiology. 2002, $10^{\text {th }}$ edition, Wiley. 
34. Roy,A., Fleming, D., Gordon, S., Effect of Chloride Concentration and $\mathrm{pH}$ on Pitting Corrosion of Waster Package Container Materials, $190^{\text {th }}$ Meeting of the Electrochemical Society, INC. December 1996, Lawrence Livermore National Laboratory.

35. Davenport, A., Aldykiewics, A.J., Isaacs, H.S., XANES Studies of Chromate Replacements in Oxide Films of Aluminum. In X-Ray Methods in Corrosion and Interfacial Chemistry. 1992: The Electrochemical Society.

36. Kendig, M., Jeanjaquet, S., Jensen, H., Non-Chromate-Inhibiting Pigments for Aluminum 2024-T3. Electrochemical Society. 1995, Chicago, IL,USA: Electrochemical Society.

37. Jeffcoate, C.S., Isaacs, H.S., Aldykiewics, A.J., Ryan, M.P. Journal of the Electrochemical Society, 2000; 147: 540.

38. Craig, B., Anderson, D., Handbook of Corrosion Data, ASM International. $2^{\text {nd }}$ Edition, 1995; 998.

39. Yang, Z., Li, Z.P., Zhang, JX., Lorimer, G.W., Robson, J., Review on Research and Development of Magnesium Alloys. Acta Metallurgica Sinica. 2008; 21: 313328.

40. G. L. Makar, J. Kruger, Int. Mater. Rev. 1993; 38:138.

41. Revie, R., Uhlig, H., Corrosion and Corrosion Control. 2008. Wiley-Interscience.

42. Crowley, J. A., D. A. Traynor, and D. C. Weatherburn. Enzymes and proteins containing manganese: an overview. 1999, p. 209-257. In A. Sigel and H. Sigel (ed.), Manganese and its role in biological processes. Metal ions in biological systems, vol. 37. Marcel Dekker, New York, N.Y.

43. Keen, C. L., J. L. Ensunsa, and M. S. Clegg. Manganese metabolism in animals and humans including the toxicity of manganese, 1999, p. 90-114. In A. Sigel and H. Sigel (ed.), Manganese and its role in biological processes. Metal ions in biological systems, vol. 37. Marcel Dekker, New York, N.Y.

44. Culotta, V.C., Yang, M., Hall, M., Manganese Transport and Trafficking: Lessons Learned from Saccharomyces cerecvisiae. Eukaryotic Cell. 2005; 4: 1159-1165.

45. Cypher, G., Copper and Human Health and Safety, International Copper Association Limited, 260 Madison Avenue, New York, NY 10016, USA. 
46. Strausak, D., Mercer, JF. Dieter, HH. Stremmel, W., Multhaup, G., Copper in Disorders with Neurological Symptoms: Alzheimer's, Menkes, and Wilson Disease. Brain Research Bulletin. 2001; 55: 175-178.

47. Leone, N., Courbon, D., Ducimetiere, P., Zureik, M., Zinc, Copper, and Magnesium, and Risks for All-Cause, Cancer, and Cardiovascular Mortality. Epidemiology. 2006; 17: 308-314.

48. Suman, C., SAE Technical Paper No. 910416 (Warrendale, PA, Society of Automotive Engineering, 1991.

49. Mackowiak, P. A., Wasserman, S. S, Levine, M. M. "A critical appraisal of 98.6 degrees $\mathrm{F}$, the upper limit of the normal body temperature, and other legacies of Carl Reinhold August Wunderlich". JAMA. 1992; 268: 1578-1580.

50. Banks, W.A.; Kastin, AJ. Aluminum-induced neurotoxicity: alterations in membrane function at the blood-brain barrier. Neuroscience Biobehavior Review. 1989; 13: $47-5$.

51. Darbre, P. D. Metalloestrogens: an emerging class of inorganic xenoestrogens with potential to add to the oestrogenic burden of the human breast. Journal of Applied Toxicology.2006; 26: 191-197.

52. Rondeau, V., Jacqmin-Gadda, H., Commenges, D., Helmer, C., Dartigues, J.F. Aluminum and Silica in Drinking Water and the Risk of Alzheimer's Disease or Cognitive Decline: Findings From 15-Year Follow-up of the PAQUID Cohort. American Journal of Epidemiology. 2008; 169: 489-96.

53. Yumoto, S., Kakimi, S., Ohsaki, A., Ishikawa, A., Demonstration of aluminum in amyloid fibers in the cores of senile plaques in the brains of patients with Alzheimer's disease. Journal of Inorganic Biochemistry. 2009; 103: 1579-84.

54. Bach., F.W., Schaper, M., and C. Jaschik, Material Science Forum. 2003; 1037: 419422.

55. Rho, J.Y., Ashman, R.B., Turner, C.H., Young's Modulus of Trabecular and Cortical Bone Material: Ultrasonic and Microtensile Measurements. Journal of Biomechanics. 1993; 26: 111-119.

56. Seal, C.K., Vince, K., Hodgson, M.A., Biodegradable Surgical Implants Based on Magnesium Alloys- A Review of Current Research. Material Science and Engineering. 2009; 4: 1-5.

57. Zberg, B., Uggowitzer, P., Loffler, J., MgZnCa Glasses without Clinically Observable Hydrogen Evolution for Biodegradable Implants. Nature MaterialsLetters. 2009; 8: 887- 891. 
58. Broadley, M. R., White, P. J., Hammond, J. P., Zelko I., Lux A. Zinc in plants, New Phytologist. 2007; 173: 677.

59. Prasad A. S., Zinc in human health: effect of zinc on immune cells, Molecular Medicine. 2008; 14: 353.

60. Zinc's role in microorganisms is particularly reviewed in: Sugarman B, "Zinc and infection", Review of Infectious Disease. 1983: 137.

61. Cotton, F.A., Advanced Inorganic Chemistry,Wiley.1999: 625-629.

62. Brandt, E.G., Hellgren, M., Brinck, T., Bergman, T., Edholm, O., Molecular dynamics study of zinc binding to cysteines in a peptide mimic of the alcohol dehydrogenase structural zinc site. Physical Chemistry Chemical Physics. 2009; 11: $975-83$.

63. Bothwell, D. N., Mair, E.A., Cable, B.B., Chronic Ingestion of a Zinc-Based Penny. Pediatrics. 2003; 111: 689.

64. Gao, JC., Wu, S., Qiao, L., Wang, Y., Corrosion Behavior of Mg and Mg-Zn Alloys in Simulated Body Fluid. Transactions of Nonferrous Metals Society of China. 2008; 18: 588-592.

65. McCafferty, E., Introduction to Corrosion Science. Springer.USA. 2010.

66. Song, G., Atrens, A., John, D., Nairn, J., Li, Y., The electrochemical corrosion of pure magnesium in 1N NaCl. Corrosion Science. 1997; 39: 855.

67. H. A. Robinson, Trans. Electrochem. Soc. 1958; 90: 485.

68. Wang, L., Zhang, BP., Shinohara, T., Corrosion Behavior of AZ91Magnesium Alloy in Dilute $\mathrm{NaCl}$ Solutions. Materials and Design. 2010; 31: 857-863.

69. Song, G., Atrens, A., Li, Y., Zhang, B., Negative Difference Effect of Magnesium. Proc. Corrosion and Prevention -97, Australasian Corrosion Association, Inc., 1997, p. 38.

70. Baboian, R., Corrosion Tests and Standards: Application and Interpretation, $2^{\text {nd }}$ Edition. ASTM International. 2005; 20.

71. Orazem, M., Tribollet, B., Electrochemical Impedance Spectroscopy. WileyInterscience, USA. 2008. 
72. ASTM Standard G61, "Standard Test Method for Conducting Cyclic Potentiodynamic Polarization Measurements for Localized Corrosion Susceptibility of Iron-, Nickel or Cobalt-Based Alloys", Annual book of ASTM Standards, Philadelphia, PA: ASTM.

73. Kossowsky, R., Surface Modification Engineering: Fundamental Aspects. Volume 1, CRC Press, 1989; 389.

74. Hamdy, A., Shenawy, E., Bitar, T., Electrochemical Impedance Spectroscopy Study of the Corrosion Behavior of Some Niobium Bearing Stainless Steels in 3.5\% $\mathrm{NaCl}$. International Journal of Electrochemical Science. 2006; 1: 171-180.

75. Mueller, W., Nascimento, M., Zeddies, M., Corsico, M., Gassa, L., Lorenze de Mele, M. Magnesium and its Alloys as Degradable Biomaterials. Corrosion Studies Using Potentiodynamic and EIS Electrochemical Techniques. Materials Research. 2007; 10: 5-10.

76. Ratner, B., Biomaterials Science: An Introduction to Materials in Science. Academic Press, $2^{\text {nd }}$ Edition. 2004; 851.

77. White, R.E., Bockris, J. O’M., Conway, B.E., Electrochemical Aspects of Stress Corrosion Cracking. Modern Aspects of Electrochemistry. 1995; 27: 234.

78. Bockris, J. O’M., Reddy, A., Modern Electrochemistry 2B. Springer, USA, 2000.

79. Hassiotis, N., Petropoulos, G. Influence of Surface Roughness on Corrosion Resistance of Turned Carbon Steel Parts. International Journal of Machining and Machinability of Materials. 2006; 1: 202-212.

80. Landolt, D., Corrosion and Surface Chemistry of Materials, CRC Press, USA, 2007.

81. Williams, R., Williams, D., Albumin Adsorption on Metal Surfaces. Biomaterials. 1988; 9: 206-212.

82. Williams, D., Askill, I., Smith, R., Protein Adsorption and Desorption Phenomena on Clean Metal Surfaces. Journal Biomedical Materials Research. 1985; 19: 313320 . 


\section{CHAPTER 3 \\ MECHANICAL PROPERTIES and TENSILE FAILURE ANALYSIS OF NOVEL BIO-ABSORBABLE Mg-Zn-Cu and Mg-Zn-Se ALLOYS}

\subsection{Introduction}

Magnesium alloys present new opportunities for biomedical applications because of their high strength and lightweight properties with favorable biocompatibility [1]. Most endovascular stents currently available today are permanent and made from corrosion resistant metals such as stainless steel, Nitinol, and cobalt-chromium alloys. A material's mechanical properties used for such purposes dictate its ability to withstand the device forming processes and applied mechanical stresses before failing once implanted within the body. Stents are widely used because they can prevent or reduce the tendency for vessel restenosis after an angioplasty leading to shrinkage of the lumen [2]. Thus, careful material selection is required that allow it to expand narrowed vessels permitting the natural flow of fluids to perfuse an area of arterial damage and to act as a biological scaffold while maintaining the appropriate mechanical integrity to withstand interfacial shear stress induced by intraluminal blood flow. However, the widely used permanent prosthetic devices have several unfavorable clinical shortcomings when implanted in the human body that prevent them from being deemed as ideal devices. Some of these limitations include: long-term endothelial dysfunction, delayed re-endothelialization, thrombogenicity, permanent physical irritation, chronic inflammatory local reactions, mismatches in mechanical behavior between stented and non-stented vessel areas, inability to adapt to growth in young patients, and importantly non-permissive or disadvantageous characteristics for later surgical revascularization [3, 4]. It is anticipated 
that the development of these experimental as-cast magnesium alloys will help address some of the challenges facing current materials used for stenting applications such as chronic inflammation, restenosis, and thrombosis.

Ideally, once a stent is implanted within a vessel, the walls of the stents become lined with endothelial cells preventing thrombosis, and after approximately 6-12 months arterial remodeling and healing is achieved [3]. After healthy arterial healing and remodeling has been achieved, there is no longer a functional need for the stent. Recognizing such an idea, the development of biodegradable stents that can degrade once the objectives of permanent stents have been fulfilled is currently being explored [2, 4-6]. Although, there are very few metallic materials that can fulfill such physiological criteria; magnesium and its alloys possess the ability to degrade once implanted and minimize adverse biological effects.

In this study the mechanical properties and tensile failure mechanism of two novel biodegradable alloys for endovascular medical applications, $\mathrm{Mg}-\mathrm{Zn}-\mathrm{Se}$ and $\mathrm{Mg}-\mathrm{Zn}-\mathrm{Cu}$, are characterized. The elastic modulus (E) and surface hardness $(\mathrm{H})$ for both the bare alloys and the air formed oxide layer were characterized by nanoindentation methods. Xray photoelectron spectroscopy (XPS) was used to determine the chemical composition of the oxide layer. Tensile strength $\left(\sigma_{\max }\right)$, and elongation at failure were determined using traditional tensile testing procedures and the poisson ratio $(v)$ for each alloy was calculated.

Additionally, the fracture mechanisms of the alloys have been investigated by scanning electron microscopy (SEM) and energy-dispersive X-ray spectroscopy (EDS). After carefully examining the existing literature, it was determined that this is the first 
paper to present these alloy compositions with supporting data and the potential application to serve as endovascular medical devices.

\subsection{Materials and Methods}

\subsubsection{Alloy Manufacturing and Sample Preparation}

The alloys compositions were synthesized using an Arc-melting method in inert argon gas at ACI Alloys, Inc (CA, USA). Both alloy compositions were composed of wt.\% ratios (98/1/1) Mg-Zn-Se/Cu. Materials were cast in a 1 in. x 1 in. x 6 in. mold. Test specimens were cut into ASTM-E8-11 subsize specimen dimensions.

Table 3-1. Composition of Ternary Magnesium Alloys

\begin{tabular}{|c|c|c|c|c|}
\hline Alloy Composition & Wt.\% Mg & Wt.\% Zn & Wt.\% Cu & Wt.\% Se \\
\hline $\mathrm{Mg}-\mathrm{Zn}-\mathrm{Se}(98 / 1 / 1)$ & 98 & 1 & - & 1 \\
\hline $\mathrm{Mg}-\mathrm{Zn}-\mathrm{Cu}(98 / 1 / 1)$ & 98 & 1 & 1 & - \\
\hline
\end{tabular}

Samples were mechanically dry ground to \#1200 grit finish using silicon carbide abrasive paper. Samples were further polished to a $2 \mu \mathrm{m}$ finish using an alumina suspension. After mechanical polishing, samples were cleaned in acetone and rinsed with deionized water and blown dry with nitrogen gas. Materials were stored in a plastic container until further testing.

\subsubsection{XPS Analysis}

Samples were stored in a sealed plastic container for 4-months to allow an air formed oxide layer to develop on the surface of the polished alloys. The oxide layer composition was characterized using a Physical Electronics 5400 ECSA (XPS) system, with a minimum analysis time of 40 minutes. A maximum radiation level of $1100 \mathrm{eV}$ was used for analysis on all samples. 


\subsubsection{Nanoindentation Analysis}

Nanoindentation analysis was performed to determine the elastic modulus (E) and surface hardness $(\mathrm{H})$ of both the bare metal alloys and samples with an air formed oxide layer. Testing was conducted using a TI 950 TriboIndenter at the Hysitron Testing Facility (MN, USA). The tests were performed using a diamond Berkovich indenter probe. Tests were in load-controlled feedback mode with a 5 second linear loading to a peak force of $10 \mathrm{mN}$, a 10 second hold at peak force, and a 5 second linear unloading duration. Tests were conducted in accordance with the Oliver-Pharr analysis method with a $5 \times 5$ analysis grid [7]. According to the Oliver-Pharr methodology, nanoindentation tests are performed by applying a force to drive an indenter probe into the surface of a sample and then reducing the force to withdraw a probe. The applied load and indenter displacement into the sample are continuously monitored. After experimentation, a load vs. displacement curve can be generated from collected data and sample hardness and elastic modulus can be calculated from the curve. Indentation testing was performed on the samples after the 4-month aging to determine the mechanical properties of the oxide layer. Later, the oxide layer was removed from the samples by mechanically polishing for revaluation. Afterwards, indentation was performed to determine $\mathrm{E}$ and $\mathrm{H}$ of the bare metal samples. 


\subsubsection{Material Density Calculation}

The density of each experimental alloy composition was determined using Archimedes principle as shown in Eq. (1). Distilled water was used as the liquid for testing with a density of $1 \mathrm{~g} / \mathrm{cm}^{3}\left(\rho_{\mathrm{w}}\right)$. W is the weight of the object, and $\mathrm{W}_{\mathrm{a}}$ is the apparent weight of the object in water.

$$
\rho=\left(\frac{W}{W-W a}\right) \rho_{w}
$$

\subsubsection{Tensile Testing}

Tensile testing specimens were prepared in accordance with ASTM standard E811 subsize specimen specifications. Testing was conducted using a MTS Bionix 358.02 servohydraulic test system. Tensile tests were conducted at room temperature with a load cell of $1 \mathrm{kN}$ and a crosshead speed of $0.2 \mathrm{~mm} / \mathrm{min}$. From the stress/strain data curves, $0.2 \%$ offset yield values were determined. Elongation at failure was calculated from actual testing specimens and cross-referenced with data from stress/strain curves using Eq. (2), where $\mathrm{L}$ is the final stressed length and $\mathrm{L}_{0}$ is the unstressed length. Poisson Ratio $(v)$ was also calculated from physical measurements of the tensile specimens after testing

using Eq. (3). The average gauge length value for all test specimens before testing was 30 $\mathrm{mm}$, with an average width and thickness of $6.3 \mathrm{~mm}$ and $2.1 \mathrm{~mm}$, respectively. Tensile specimens were machined in the long dimension of the 1 in. $\mathrm{x} 1$ in. $\mathrm{x} 6$ in. as-cast bar. Testing in additional directions was not possible due to the casting mold used. Tensile testing was repeated on five samples, and the data is reported as the statistical mean \pm standard deviation (Table 3-2). 


$$
\begin{gathered}
\mathcal{E}=\left(\mathrm{L}-\mathrm{L}_{0}\right) / \mathrm{L} \\
v=-\left(\varepsilon_{\text {Strain Lateral })} /\left(\mathcal{E}_{\text {Strain Axial }}\right)\right.
\end{gathered}
$$

\begin{tabular}{|c|c|c|c|c|c|c|}
\hline $\begin{array}{c}\text { Alloy } \\
\text { Composition }\end{array}$ & $\begin{array}{l}\text { Method of } \\
\text { Analysis }\end{array}$ & $\begin{array}{c}\text { Elastic } \\
\text { Modulus } \\
\text { (E) } \\
\text { [GPa] }\end{array}$ & $\begin{array}{c}\text { Surface } \\
\text { Hardness } \\
\text { (H) } \\
{[\text { GPa] }}\end{array}$ & $\begin{array}{c}\text { Elastic } \\
\text { Modulus of } \\
\text { Oxide } \\
\text { Layer } \\
(E) \\
\text { [GPa] }\end{array}$ & $\begin{array}{c}\text { Surface } \\
\text { Hardness } \\
\text { of Oxide } \\
\text { Layer } \\
\text { (H) } \\
\text { [GPa] }\end{array}$ & $\begin{array}{c}\text { Density }^{\text {a }} \\
(\rho) \\
{\left[\mathrm{g} \cdot \mathrm{cm}^{-3}\right]}\end{array}$ \\
\hline $\mathrm{Mg}-\mathrm{Zn}-\mathrm{Se}$ & Nanoindentation & $38 \pm 4$ & $\begin{array}{c}0.69 \pm \\
0.07\end{array}$ & $55 \pm 9$ & $1.2 \pm 0.3$ & 1.75 \\
\hline $\mathrm{Mg}-\mathrm{Zn}-\mathrm{Cu}$ & Nanoindentation & $41 \pm 3$ & $\begin{array}{c}0.62 \pm \\
0.07\end{array}$ & $60 \pm 13$ & $1.3 \pm 0.3$ & 1.76 \\
\hline $\mathrm{Mg}-\mathrm{Zn}-\mathrm{Se}$ & $\begin{array}{c}\text { Stress-Strain } \\
\text { Curve }\end{array}$ & $11 \pm 6$ & - & - & - & - \\
\hline $\mathrm{Mg}-\mathrm{Zn}-\mathrm{Cu}$ & $\begin{array}{l}\text { Stress-Strain } \\
\text { Curve }\end{array}$ & $11 \pm 1$ & - & - & - & - \\
\hline
\end{tabular}

Table 3-2. Mechanical Properties of Ternary Magnesium Alloys.

* Data is represented as mean \pm standard deviation; ${ }^{\mathrm{a}} \mathrm{n}=5$

\subsubsection{Fracture Analysis by Scanning Electron Microscopy and Energy Dispersive X-ray Spectroscopy}

The fractured surfaces were examined after tensile testing using a JEOL JSM 5900 LV (SEM) and EDS-UTW detector system (EDS). Images were analyzed in both secondary electron imaging (SEI) and backscatter electron imaging (BEI) modes at an accelerating voltage of $20 \mathrm{KeV}$. 


\subsection{Results}

\subsubsection{Mechanical Properties of Bare Alloys and Air Formed Oxide Layer Using Nanoindentation}

Table 3-2 summarizes the mechanical properties of the bare magnesium alloys and the air formed oxide layer. The bare $\mathrm{Mg}-\mathrm{Zn}-\mathrm{Se}$ alloy had a lower elastic modulus than $\mathrm{Mg}-\mathrm{Zn}-\mathrm{Cu}$. Notably, the air formed oxide layers on both $\mathrm{Mg}-\mathrm{Zn}-\mathrm{Se}$ and $\mathrm{Mg}-\mathrm{Zn}-\mathrm{Cu}$ were revealed to possess higher $(\mathrm{E})$ and $(\mathrm{H})$ values than bare metal alloys. Reported oxide layer $(\mathrm{H})$ values nearly doubled when compared with bare metal $(\mathrm{H})$ values for both alloy compositions.

Backscatter imaging confirmed the formation of an oxide layer on the $\mathrm{Mg}-\mathrm{Zn}-\mathrm{Se}$ alloy. Backscatter imaging also revealed the presence of different regions of contrast within the air formed oxide layer [Fig. 3-1C]. After mechanical polishing, backscatter imaging of the alloy did not reveal any separable phases as seen in the oxide layer prior to polishing [Fig. 3-1D]. XPS analysis of the oxide layer determined significant deposition of magnesium (15.2\%), oxygen (35.5\%), and carbon (40.9\%) which would readily form $\mathrm{MgO}, \mathrm{Mg}(\mathrm{OH})_{2}$ and $\mathrm{MgCO}_{3}$ on the surface of the material [Fig. 3-1]. Aluminum (5.9\%) and nitrogen (2.5\%) deposits were also identified from the XPS spectrum. The room temperature density of the $\mathrm{Mg}-\mathrm{Zn}-\mathrm{Se}$ material, was determined to be $1.75\left(\mathrm{~g} \cdot \mathrm{cm}^{-3}\right)($ Table $3-2)$. 


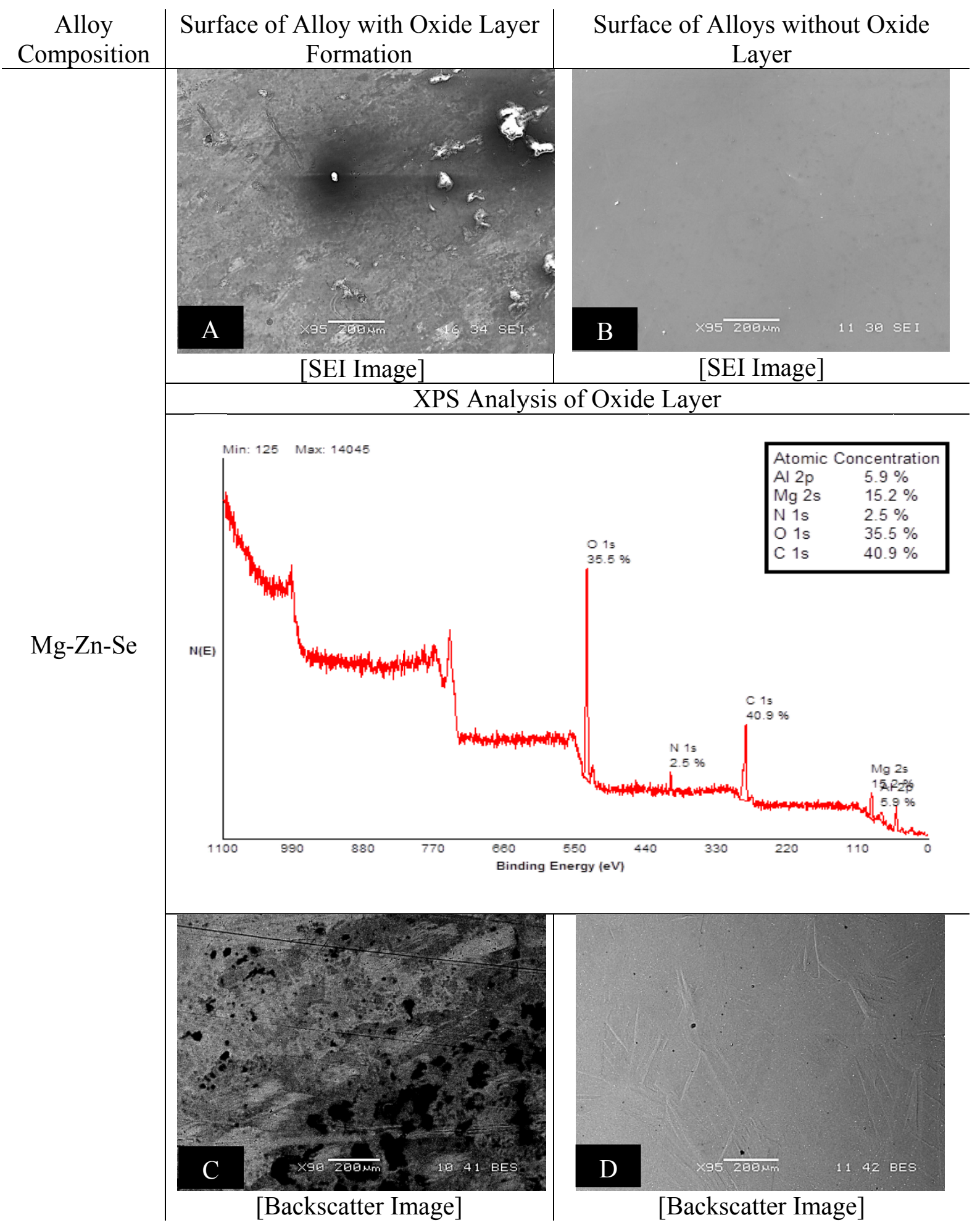

Figure 3-1. SEM Images and XPS Analysis of Oxide Layer Formation on the Mg-Zn-Se Alloy. 
Comparably, backscatter imaging confirmed the formation of an oxide layer on the Mg-Zn-Cu alloy. As seen in Figure 3-2, backscatter imaging revealed different regions of contrast within the air formed oxide layer [Fig. 3-2C]. After the abrasive removal of the oxide layer, backscatter imaging of the alloy reveals two separable contrast regions along the grain boundaries and grains of the material [Fig. 3-2D]. XPS analysis of the oxide layer portions showed significant deposition of magnesium (14\%), oxygen (43.6\%), and carbon (33.4\%) [Fig. 3-2]. Aluminum (8.8\%) deposits were also detected on the surface of the $\mathrm{Mg}-\mathrm{Zn}-\mathrm{Cu}$ alloy in larger amounts than was detected on $\mathrm{Mg}-\mathrm{Zn}-\mathrm{Se}(5.9 \% \mathrm{Al})$. The room temperature density of the $\mathrm{Mg}-\mathrm{Zn}-\mathrm{Cu}$ material, was determined to be $1.76\left(\mathrm{~g} \cdot \mathrm{cm}^{-3}\right)$ (Table 3-2).

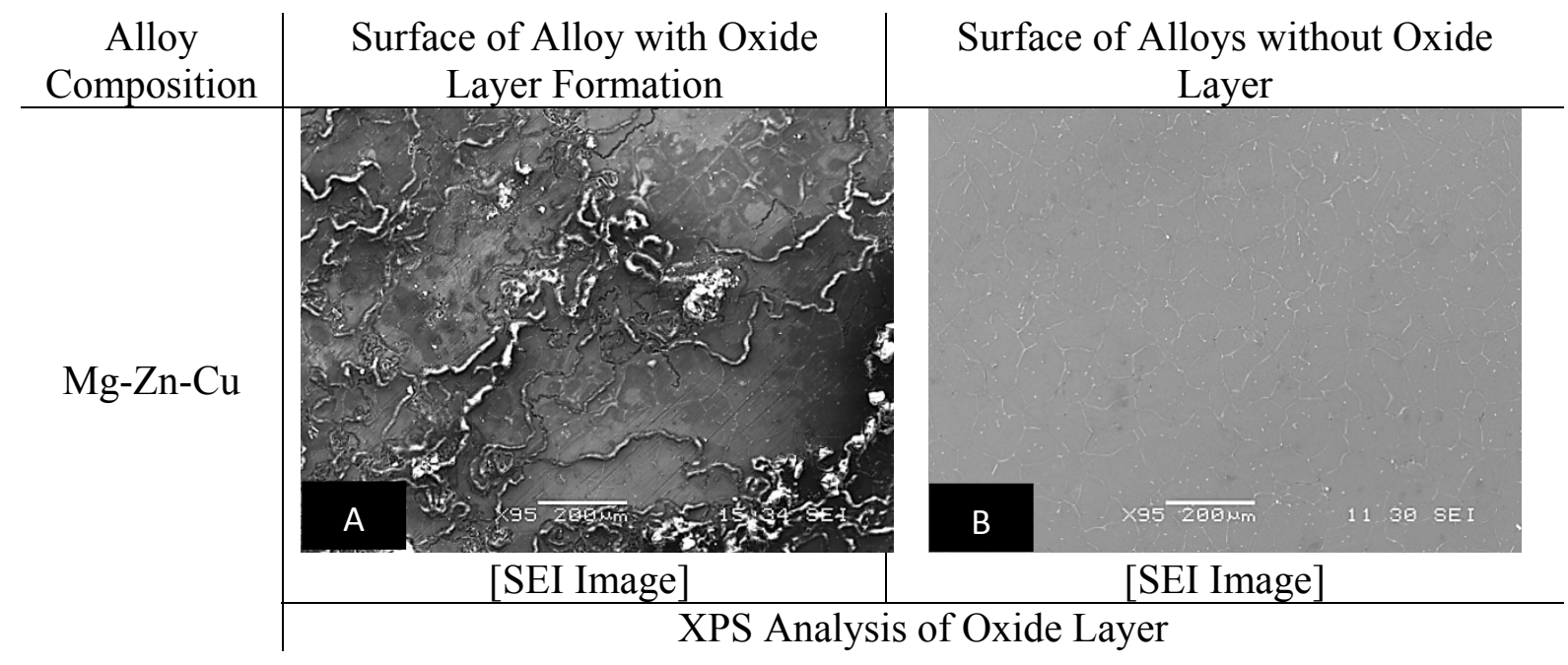




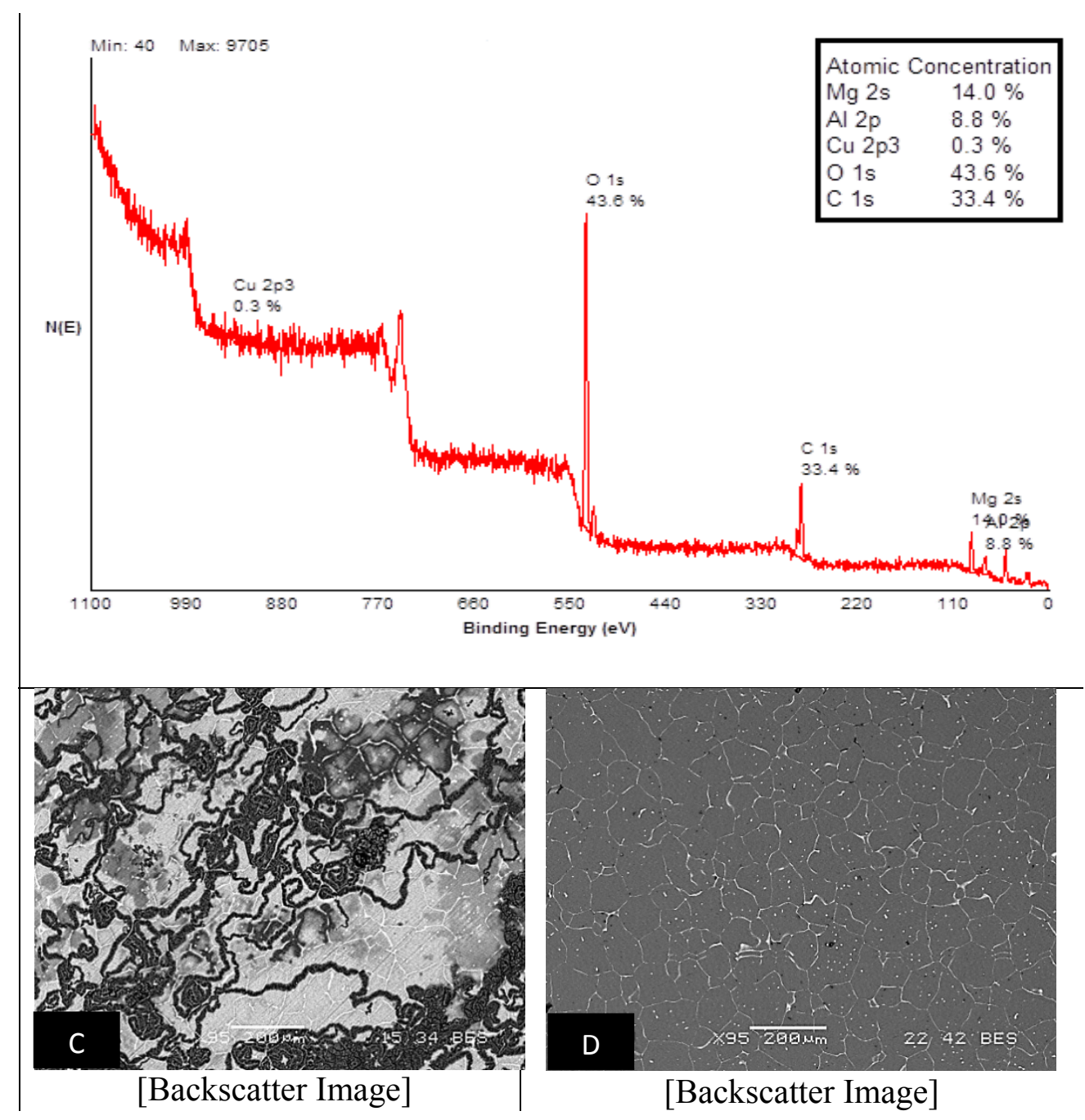

Figure 3-2. SEM Images and XPS Analysis of Oxide Layer Formation on the $\mathrm{Mg}-\mathrm{Zn}-\mathrm{Cu}$ Alloy.

\subsubsection{Evaluation of Mechanical Properties}

Table 3-3 summarizes the tensile properties of $\mathrm{Mg}-\mathrm{Zn}-\mathrm{Cu}$ and $\mathrm{Mg}-\mathrm{Zn}-\mathrm{Se}$ alloys compared to materials that are widely used for endovascular biomedical applications. Both $\mathrm{Mg}-\mathrm{Zn}-\mathrm{Se}$ and $\mathrm{Mg}-\mathrm{Zn}-\mathrm{Cu}$ have similar tensile strength values ranging from 152$159 \mathrm{MPa}$. Offset yield strength $(0.2 \%)$ for both $\mathrm{Mg}-\mathrm{Zn}-\mathrm{Cu}$ and $\mathrm{Mg}-\mathrm{Zn}-\mathrm{Se}$ was lower than martensitic Nitinol, Pt-10Ir, and Mg-3A1-1Z. Notably, Mg-Zn-Cu had a higher 
elongation at failure than $\mathrm{Mg}-\mathrm{Zn}-\mathrm{Se}$, work-hardened martensitic Nitinol, and had a comparable value to $\mathrm{Mg}-3 \mathrm{~A} 1-1 \mathrm{Z}$. $\mathrm{Mg}-\mathrm{Zn}-\mathrm{Cu}$ was revealed to possess a lower (v) of 0.27 while Mg-Zn-Se had a (v) of 0.39 which is comparable to that of annealed Pt-10Ir. Nanoindentation testing showed the $\mathrm{Mg}-\mathrm{Zn}-\mathrm{Se}$ and $\mathrm{Mg}-\mathrm{Zn}-\mathrm{Cu}$ alloys to possess a mean elastic modulus $38 \mathrm{GPa}$ and $41 \mathrm{GPa}$, respectively. Stress-strain curve analysis, revealed $\mathrm{Mg}-\mathrm{Zn}-\mathrm{Se}$ and $\mathrm{Mg}-\mathrm{Zn}-\mathrm{Cu}$ alloys both to possess an elastic modulus of $11 \mathrm{GPa}$. Thus, comparable tensile strength, higher elongation at failure values, reduced elastic modulus values for both nanoindentation and MTS testing, and poisson ratio values similar to materials currently used for endovascular applications indicates the potential use of Mg$\mathrm{Zn}-\mathrm{Se}$ and $\mathrm{Mg}-\mathrm{Zn}-\mathrm{Cu}$ alloys for endovascular biomedical applications. 
Table 3-3. Tensile Properties of Ternary Magnesium Alloys at room temperature $\left(25^{\circ} \mathrm{C}\right)$.

\begin{tabular}{|c|c|c|c|c|}
\hline $\begin{array}{c}\text { Alloy } \\
\text { Composition }\end{array}$ & $\begin{array}{c}0.2 \% \text { Offset } \\
\text { Yield Strength } \\
\text { [MPa] } \\
\end{array}$ & $\begin{array}{c}\text { Tensile } \\
\text { Strength }[\mathrm{MPa}] \\
\left(\sigma_{\max }\right) \\
\end{array}$ & $\begin{array}{c}\text { Elongation at } \\
\text { Failure (\%) } \\
(\mathcal{E}) \\
\end{array}$ & $\begin{array}{c}\text { Poisson } \\
\text { Ratio } \\
(v) \\
\end{array}$ \\
\hline $\mathrm{Mg}-\mathrm{Zn}-\mathrm{Se}$ & $51 \pm 23$ & $159 \pm 29$ & $12 \pm 4$ & $0.39 \pm 0.04$ \\
\hline $\mathrm{Mg}-\mathrm{Zn}-\mathrm{Cu}$ & $59 \pm 12$ & $152 \pm 8$ & $13 \pm 1$ & $0.27 \pm 0.09$ \\
\hline $\begin{array}{l}\text { Martensitic } \\
\text { Nitinol }\end{array}$ & $200-300^{a}$ & $70-140^{b}$ & $\begin{array}{c}5-10 \\
\text { (work-hardened) } \\
b\end{array}$ & $0.33^{\mathrm{b}}$ \\
\hline $\begin{array}{l}\text { Platinum-10Ir } \\
\text { Annealed }\end{array}$ & $200^{\mathrm{a}}$ & $380^{\mathrm{c}}$ & $20^{\mathrm{c}}$ & $0.38^{\mathrm{d}}$ \\
\hline Mg-3A1-1Z & $162^{\mathrm{a}}$ & $255^{\mathrm{a}}$ & $10-25^{\mathrm{a}}$ & - \\
\hline
\end{tabular}

${ }^{a}$ Poncin P, Proft J, Stent Tubing: Understanding the desired attributes. Materials and

Processes for Medical Devices conference proceedings. ASM International. 2003.

${ }^{\mathrm{b}}$ Nitinol: http://jmmedical.com/resources/221/Nitinol-Technical-Properties.htm as of 6/15/12.

${ }^{\mathrm{c}}$ Sandvik Bioline Pt/Ir

:http://www2.sandvik.com/sandvik/0140/internet/se01598.nsf/cdatas/AA573A7633EECC13 C12574BE0046E612 as of 6/15/12.

${ }^{\mathrm{d}}$ Merker J, Lupton D, Topfer M, Knake H, High temperature mechanical properties of the platinum group metals. Platinum Metals Review. 2001; 45: 74-82.

* Data is represented as Mean \pm Standard Deviation

\subsubsection{Fracture Analysis}

The $\mathrm{Mg}-\mathrm{Zn}-\mathrm{Se}$ alloy predominantly failed by transgranular fracture, while $\mathrm{Mg}$ $\mathrm{Zn}-\mathrm{Cu}$ failed by intergranular failure. SEM images of the fractured surfaces for both alloys are shown in Figure 3.

Mg-Zn-Se transgranular brittle fractured surfaces can be seen in Figure 3-3A-D, which are characterized by smooth faced fractured surfaces. Intergranular failure of $\mathrm{Mg}$ $\mathrm{Zn}-\mathrm{Cu}$ can be seen in Figure 3-3E-F, characterized by fracture along adjacent grain facets. Tensile specimens for both alloys revealed to be moderately ductile with characteristic fibrous and shear portions (Fig. 3-4). Mg-Zn-Cu also showed slight cup- 
cone fracture behavior (Fig. 3-4B). Further SEM elemental analysis on fractured Mg-Zn-

$\mathrm{Cu}$ samples showed an increased concentration of copper primarily observed along the grain boundaries of the material and on portions of the grain as seen in Figure 3-5A-B. Copper deposits are identified as whitened phases within the image. EDS analyses on the white deposits highlight copper concentrations as high as 32 wt.\% (Fig. 3-5A).





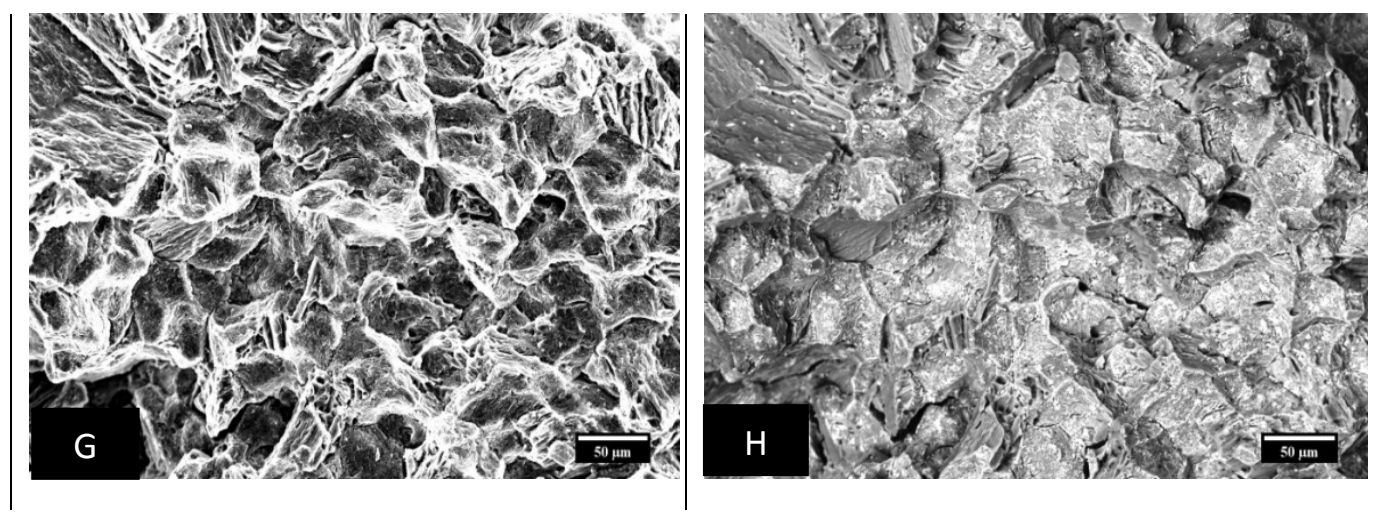

Figure 3-3. Comparative SEM Cross-Sectional Images for Magnesium Alloys after Normal Tensile Failure.
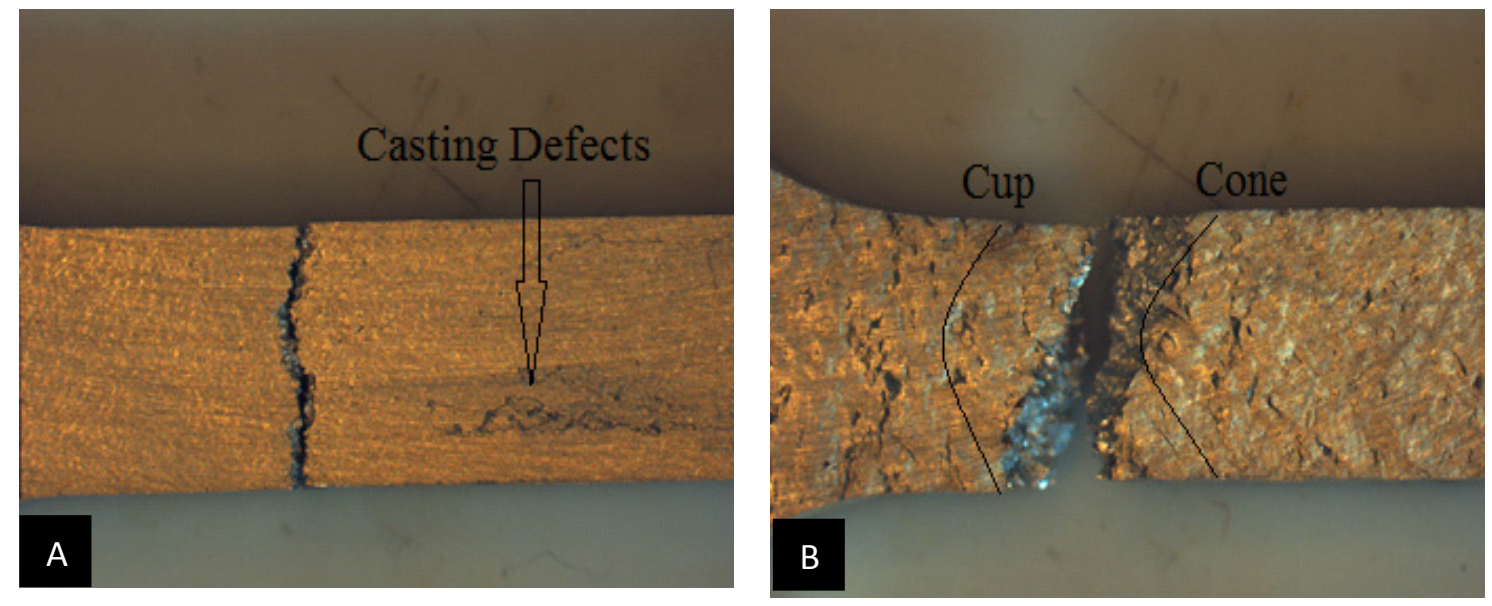

Figure 3-4. Optical Images of Tensile Specimens after Fracture.(A) Mg-Zn-Se Alloy with transgranular brittle failure with an average 12\% elongation; (B) $\mathrm{Mg}-\mathrm{Zn}-\mathrm{Cu}$ Alloy with intergranular failure with an average $13 \%$ elongation. 


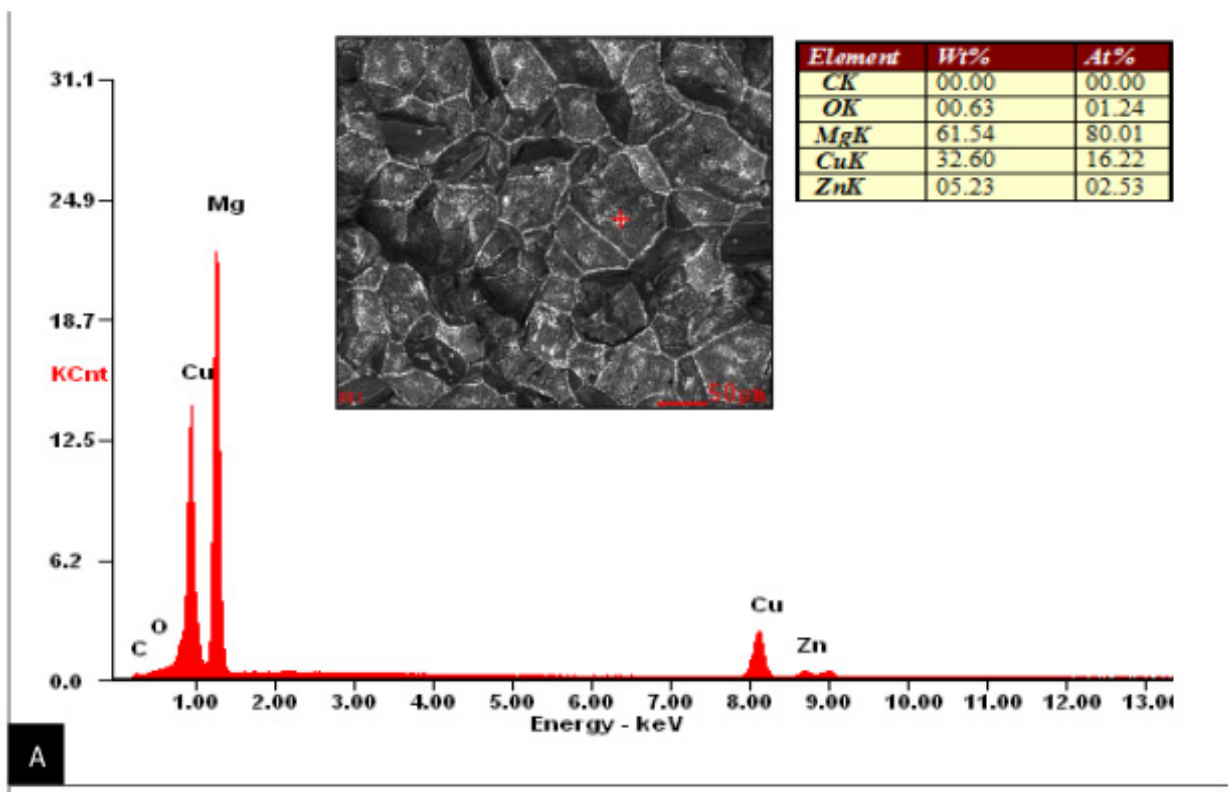

$\mathrm{Mg}-\mathrm{Zn}-\mathrm{Cu}$

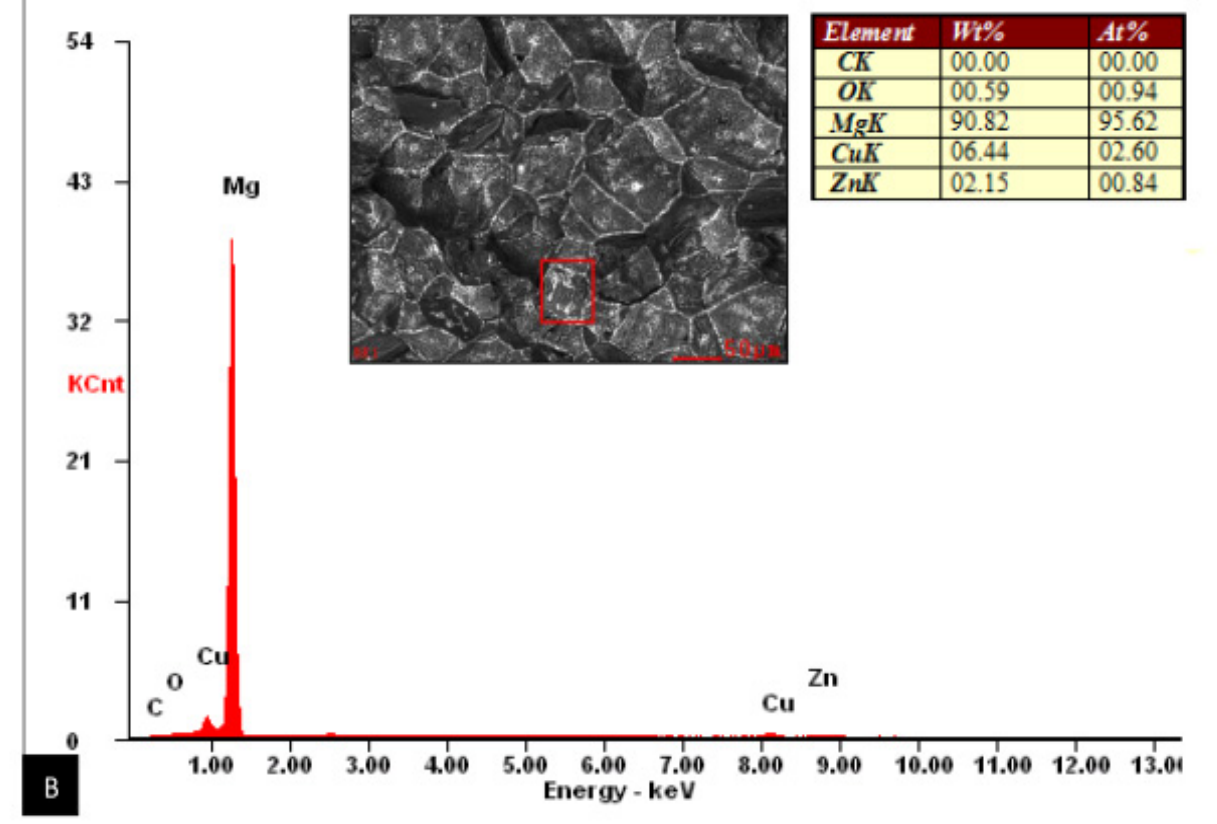

Figure 3-5. $\mathrm{Mg}-\mathrm{Zn}-\mathrm{Cu}$ Alloy with Normal Failure showing $\mathrm{Cu}$ along Boundaries of Failure.

Analysis of the Mg-Zn-Se and the Mg-Zn-Cu alloy tensile specimens that did not show the same tensile behavior as average tensile specimens, failed primarily due to casting defects. SEM analysis on such fractured surfaces confirmed material defects 
within the matrix of the alloy tensile specimens. Such defects indicate potential flaws formed during the manufacturing of the materials as well as being a result from elemental interactions within the material between $\mathrm{Mg}, \mathrm{Zn}$ and $\mathrm{Se} / \mathrm{Cu}$.

Defects within the Mg-Zn-Se tensile specimen can be seen in Figure 3-6. Backscatter SEM images clearly show the defects as a separate phase from the bulk material of magnesium (Fig. 3-6A-B). EDS analysis identified the darkened phase to consist of an elemental ratio with $29 \mathrm{wt} . \%$ of oxygen, which is consistent with the likely formation of $\mathrm{MgO}$. (Fig. 3-6C).

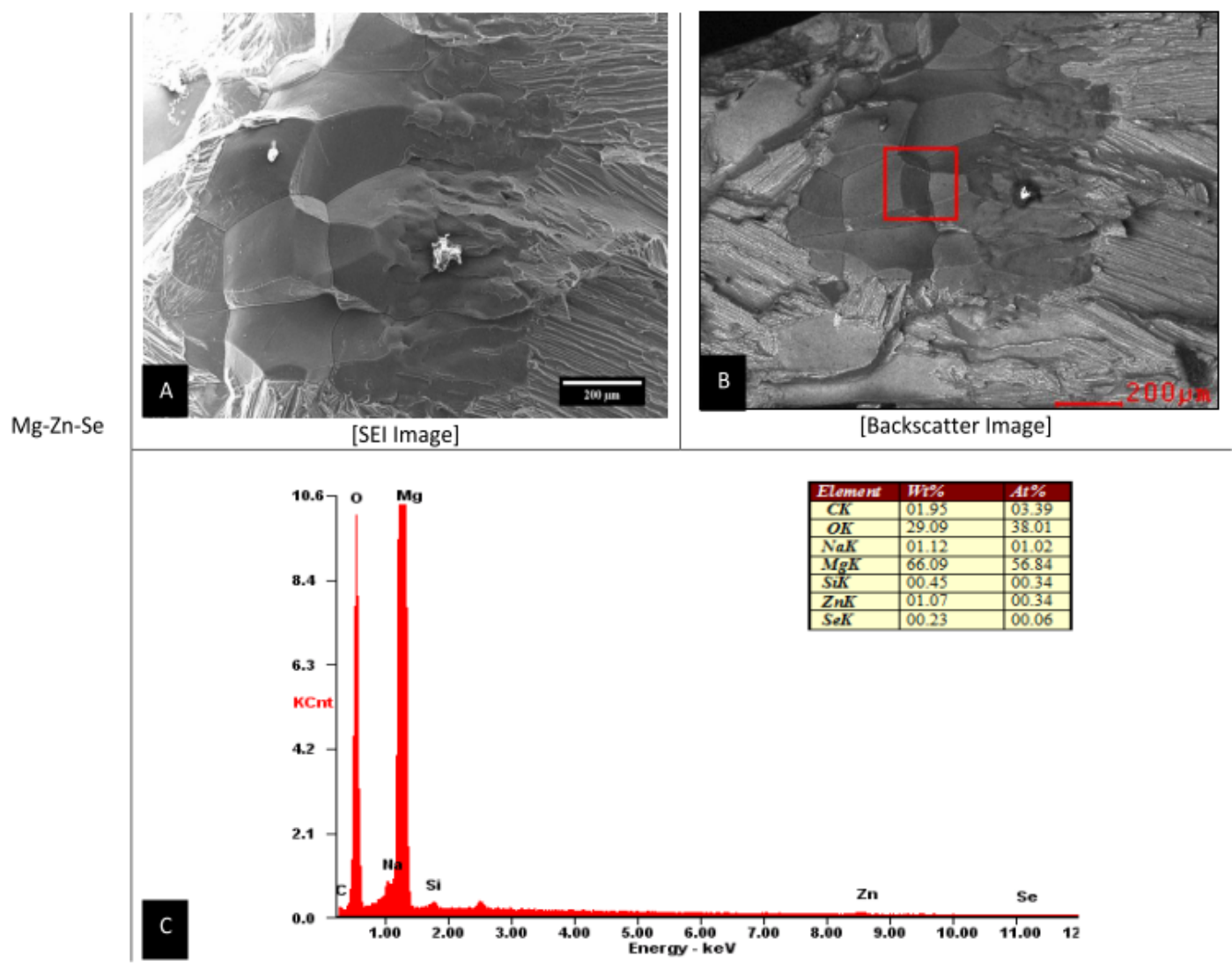

Figure 3-6. Mg-Zn-Se Alloy Casting Defect in Tensile Specimen Leading to Premature Failure. 
Prematurely failed $\mathrm{Mg}-\mathrm{Zn}-\mathrm{Cu}$ specimens reveal a similar type of deformation as was seen in the Mg-Zn-Se specimen. Backscatter SEM analysis showed the deformed portion from the remaining alloy material (Fig. 3-7B). Shear failure is evident from the smoothened surface of the material in this deformed portion, as compared to the regular intergranular failure for the specimen. EDS analysis revealed the deformed region to be composed mostly of magnesium with lower amounts of oxygen and copper (Fig. 3-7C).



Figure 3-7. Mg-Zn-Cu Alloy Casting Defect in Tensile Specimen Leading to Premature Failure. 


\subsection{Discussion}

In this paper, the mechanical properties of novel bio-absorbable materials $\mathrm{Mg}-\mathrm{Zn}$ $\mathrm{Cu}$ and $\mathrm{Mg}-\mathrm{Zn}-\mathrm{Se}$ for endovascular medical device applications are investigated. After comparing the mechanical properties of these alloys to conventionally used materials for endovascular applications such as Nitinol, Pt-10Ir, and magnesium alloys Mg-3A1-1Z, it is evident that these materials possess the qualities suitable for manufacturing endovascular medical devices. Both Nitinol and Pt-10Ir alloys possess the elasticity required to conform to vessel geometry and have a high corrosion resistance to serve as permanent implants; while the $\mathrm{Mg}-3 \mathrm{Al}-1 \mathrm{Z}$ alloy has the appropriate ductility and a reduced corrosion rate to serve as a scaffold for desired wound healing to occur [8]. The density of the $\mathrm{Mg}-\mathrm{Zn}-\mathrm{Se}$ and $\mathrm{Mg}-\mathrm{Zn}-\mathrm{Cu}$ material are very close in value to the density of Magnesium $\left(1.738 \mathrm{~g} \cdot \mathrm{cm}^{-3}\right)$, with values of 1.75 and $1.76 \mathrm{~g} \cdot \mathrm{cm}^{-3}$ respectively [9]. The increased density for the tested alloys in $\mathrm{Mg}-\mathrm{Zn}-\mathrm{Se}$ and $\mathrm{Mg}-\mathrm{Zn}-\mathrm{Cu}$ indicate that these alloys possess a higher strength to weight ratio and are more favorable to withstand compressive arterial wall stresses in the application of stents than that of pure magnesium stents. More notably, the Mg-Zn-Se alloy possesses a density nearly identical to that of a $\mathrm{Mg}$ reinforced alloy with 1.5 wt. $\% \mathrm{Al}_{2} \mathrm{O}_{3}\left(1.756 \mathrm{~g} \cdot \mathrm{cm}^{-3}\right)$ which is currently being explored for stent device applications because of its more favorable strength to weight ratio [9].

The $0.2 \%$ offset values for $\mathrm{Mg}-\mathrm{Zn}-\mathrm{Se}$ and $\mathrm{Mg}-\mathrm{Zn}-\mathrm{Cu}$ were notably lower than any of the values for martensitic Nitinol, annealed Platinum-10Ir, or the Mg-3A1-1Z alloy. The lower yield strength at the $0.2 \%$ offset compared to the other Nitinol, platinum, and magnesium alloys show that the $\mathrm{Mg}-\mathrm{Zn}-\mathrm{Se}$ and $\mathrm{Mg}-\mathrm{Zn}-\mathrm{Cu}$ alloys are more readily 
permanently deformed by an applied stress when compared to the other aforementioned materials currently used for medical devices. However, the ultimate tensile strength measurements for the Mg-Zn-Se (159 MPa) and Mg-Zn-Cu (152 MPa) alloys obtained from observed stress-strain behavior was higher before material fracture than martensitic Nitinol (70-140 MPa) as seen in Figure 3-8.

A)

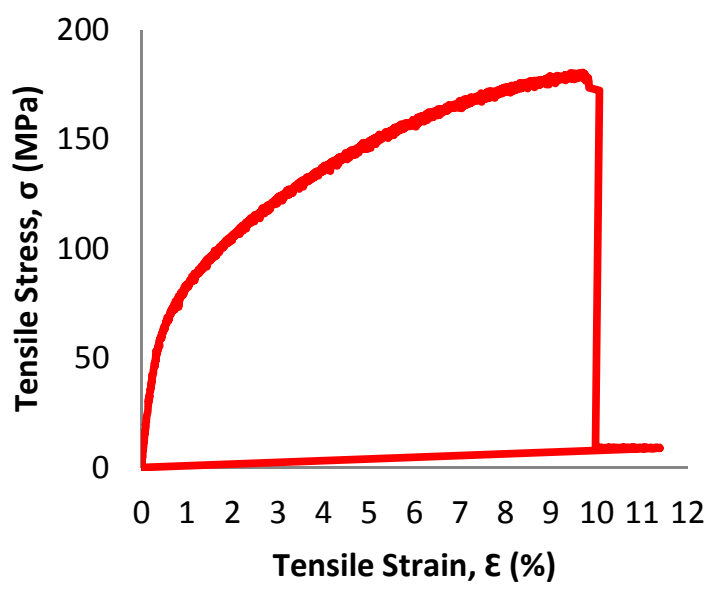

B)

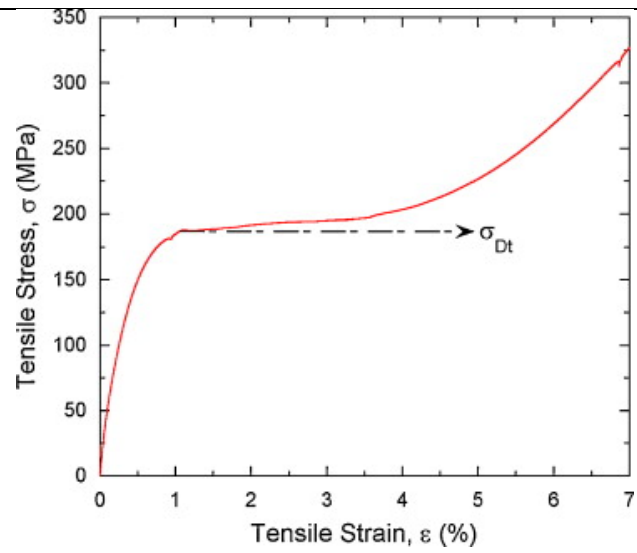


C)

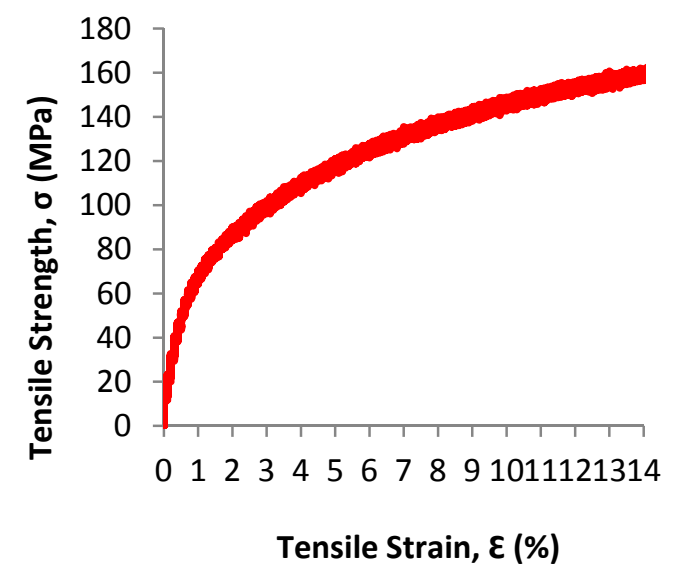

Figure 3-8. Tensile Stress-Strain Response Obtained for the $\mathrm{Mg}-\mathrm{Zn}-\mathrm{Cu}$ and the $\mathrm{Mg}-\mathrm{Zn}-\mathrm{Se}$ Alloys Compared to Martensitic Nitinol

A) Room temperature tensile stress-strain response of the $\mathbf{M g}-\mathbf{Z n}$-Se Alloy

B) Quasi-static, room temperature tensile stress-strain response of the martensitic Nitinol alloy. "Reprinted from Material Science and Engineering: A, 525, 1-2, Nayan, N., Buravalla, V., Ramamurthy, U. Effect of mechanical cycling on the stress-strain response of a martensitic Nitinol shape memory alloy, 60-67, Copyright 2009, with permission from Elsevier.

C) Room temperature tensile stress-strain response of the $\mathbf{M g}-\mathbf{Z n}-\mathrm{Cu}$ Alloy

This suggests that these $\mathrm{Mg}-\mathrm{Zn}-\mathrm{Se}$ and $\mathrm{Mg}-\mathrm{Zn}-\mathrm{Cu}$ alloys retain their strength and are more stable than NiTi alloys, which readily undergo transformation shifts between austenitic and martensitic phases at temperatures ranging from -200 to $110{ }^{\circ} \mathrm{C}$ [10]. This stability is a desirable quality for endovascular devices, as the strength of the NiTi alloys is greatly reduced during phase transformations of the austenite-martensite phase, as evident by its yield strength ranging from 70-140 MPa. However, the super elastic shape memory feature of the NiTi alloy remains highly desirable for medical devices.

The surface properties of metallic medical implants are very important to the stability, biocompatibility, and mechanical integrity of the implant [11]. An understanding and analysis of the surface oxide film formed on metallic material is directly related to the ability of metallic ions to be leached from the surface of the 
implant. The composition of the surface oxide film changes according to reactions between the surfaces of the metallic materials and living tissues and/or biological fluids, therefore it is important to understand the mechanical properties and elemental composition of the surface oxide formations [12]. In this study, it was shown that the oxide surface layer is primarily composed of oxide coatings most likely including $\mathrm{MgO}$, $\mathrm{Mg}(\mathrm{OH})_{2}$ and $\mathrm{MgCO}_{3}$. These coatings generally do not release harmful material components into biological tissues or fluids through diffusion; however, the increased basicity of the $\mathrm{Mg}(\mathrm{OH})_{2}$ layer may be unsuitable for cell adhesion and growth under static conditions because of the increased basicity of the immediate physiological environment. Other materials used for stenting applications such as Nitinol, develop airformed oxide layers composed of $\mathrm{NiO}$ and $\mathrm{TiO}_{2}$ [13]. Comparably, magnesium metals form oxide layers that are biologically soluble within the body. The modulus of elasticity (E) and surface hardness $(\mathrm{H})$ for both the bare $\mathrm{Mg}-\mathrm{Zn}-\mathrm{Se}$ and $\mathrm{Mg}-\mathrm{Zn}-\mathrm{Cu}$ and the oxide layer formed on the surface of the alloys were determined by nanoindentation testing. Generally, the $\mathrm{E}$ and $\mathrm{H}$ of the air formed oxide layer were both higher in value than the bare metal alloys for both compositions (Table 3-2). The higher E values for the oxide layers mean that the alloys require more applied stress to deform the materials (strain) than the bare metals. Additionally, the increased E of the oxide layers can lead to the development of surface cracks and lead to undesired wear, friction, and material-liquid interfacial interactions [14]. The increase in $\mathrm{H}$ of the air formed oxide layer offers a comparative idea of the materials resistance to plastic deformation [15]. The $\mathrm{H}$ values for both the bare metals and oxide layers of $\mathrm{Mg}-\mathrm{Zn}-\mathrm{Cu}$ and $\mathrm{Mg}-\mathrm{Zn}-\mathrm{Se}$ are significantly lower than $\mathrm{H}$ values widely explored for shape-memory NiTi binary and ternary alloys with 
values ranging from 1-7 $\mathrm{GPa}$ [16]. Given the material properties of the $\mathrm{Mg}-\mathrm{Zn}-\mathrm{Cu}$ and $\mathrm{Mg}-\mathrm{Zn}$-Se alloys, it is understood that these materials should possess the ability to be more compliant to elastic deformation than binary and ternary NiTi alloys because of the higher surface hardness values for NiTi alloys with and without surface treatments when measured by nanoindentation. Persaud-Sharma et al. reported bulk elastic moduli of 32$98 \mathrm{GPa}$ for electro and magneto-electropolished $\mathrm{NiTi}, \mathrm{NiTiCu}$, and NiTiTa alloys with surface hardness values ranging from 1.2 to $6.5 \mathrm{GPa}$ [16]. Comparably, the bulk elastic moduli for the $\mathrm{Mg}-\mathrm{Zn}-\mathrm{Se}$ and $\mathrm{Mg}-\mathrm{Zn}-\mathrm{Cu}$ alloys are $38 \mathrm{GPa}$ and $41 \mathrm{GPa}$ when calculated by nanoindentation methods, respectively. The lower (E) values for the experimental Mg$\mathrm{Zn}-\mathrm{Se}$ and $\mathrm{Mg}-\mathrm{Zn}-\mathrm{Cu}$ alloys indicate that they are softer and less stiff than Nitinol materials which are currently used to manufacture endovascular devices. While these materials were tested as an as-cast form, the final medical device will have some type of surface finishing which will alter the mechanical properties of the materials.

A difference in elastic modulus values exists for the $\mathrm{Mg}-\mathrm{Zn}-\mathrm{Se}$ and $\mathrm{Mg}-\mathrm{Zn}-\mathrm{Cu}$ alloys when measured by nanoindentation and MTS tensile testing procedures. The E values determined by nanoindentation showed to be greater than the $\mathrm{E}$ values determined from MTS tensile testing by a factor or 4 (Table 3-2). The first possible explanation for this observed difference in values resulting from the two analytical procedures includes the placement of the indenter tip on a non-homogenous sample. In such a sample, areas of separated elemental phases formed within the alloy may lead to different $\mathrm{E}$ and $\mathrm{H}$ values if the indent measurements are collected on or near the grain boundary. Additionally, nanoindentation tests measure a very small portion of the sample surface, almost at the dimension of a single elemental grain. Thus, if the tested sample is non- 
homogenous, multiple measurements at different areas across the sample surface $(\mathrm{n}>30)$ are needed to characterize bulk properties of the material. Conventional pull-testing procedures account for the entire alloy system inclusive of its intergranular interactions, whereas the nanonindentation technique is limited by the depth of the indent, probe tip shape, and is restrained by the quality of the surface finish. More so, this observed difference can be explained by the reduced sensitivity of the MTS equipment when compared to that of the nanoindentation system which operates on a more automated system with software filters to separate critically erroneous unloading data from the remaining load-displacement data. This matter has been extensively studied by Stauss et al., who attribute differences in microtensile and nanoindentation values to the different size and microstructural levels that are probed [17].

XPS analysis technique was used to determine the elemental composition of the outer 1-10 nm of the material surface for both $\mathrm{Mg}-\mathrm{Zn}-\mathrm{Se}$ and $\mathrm{Mg}-\mathrm{Zn}-\mathrm{Cu}$ oxide layer formation. Mg-Zn-Se showed an oxide layer atomic composition of magnesium (15.2\%), oxygen (35.5\%), and carbon (40.9\%) which would readily form $\mathrm{MgO}, \mathrm{Mg}(\mathrm{OH})_{2}$ and $\mathrm{MgCO}_{3}$ on the surface of the material (Fig. 3-1). XPS analysis of $\mathrm{Mg}-\mathrm{Zn}-\mathrm{Cu}$ showed oxide layer portions with significant deposition of magnesium (14\%), oxygen (43.6\%), and carbon (33.4\%) (Fig. 3-2). These are consistent with literature studies on similar magnesium based alloys AZ31 and AZ91, in which XPS analysis revealed the presence of $\mathrm{MgO}, \mathrm{Mg}(\mathrm{OH})_{2}$ and $\mathrm{MgCO}_{3}$ on the outer surface of both alloys [18]. The process of surface polishing is important to the corrosion performance of the experimental alloys because it is known that a smoother finished surface will reduce the effects of corrosion [16]. In an attempt to produce a smooth surface, the alloys were polished to create a 
smooth surface using an alumina based paste. It has been concluded that the $5.9 \% \mathrm{Al}$ and $8.8 \% \mathrm{Al}$ found on the surface of the $\mathrm{Mg}-\mathrm{Zn}-\mathrm{Se}$ and $\mathrm{Mg}-\mathrm{Zn}-\mathrm{Cu}$ alloys are a result of the alumina based polishing paste, which was imbedded within the crevices of the alloys that was not removed during the cleaning process (Fig. 3-1 \& 3-2). The formation of $\mathrm{MgO}$, $\mathrm{Mg}(\mathrm{OH})_{2}$ and $\mathrm{MgCO}_{3}$ on the outer surface of both alloys characterize the majority of the natural oxide layer formation at $25^{\circ} \mathrm{C}$ (room temperature). Larger amounts of oxygen on the surface of the $\mathrm{Mg}-\mathrm{Zn}-\mathrm{Cu}$ alloy show that this alloy may be susceptible to an increased rate of corrosion by forming pitting sites on its surface as the increased oxygen concentration is a result of electron-transport from metal oxidation [19].

The tensile strength of as-cast $\mathrm{Mg}-\mathrm{Zn}-\mathrm{Cu}(152 \mathrm{MPa})$ and $\mathrm{Mg}-\mathrm{Zn}-\mathrm{Se}(159 \mathrm{MPa})$ were lower than annealed Pt-10Ir (380 MPa), and Mg-3A1-1Z (255 MPa), but most comparable to martensitic Nitinol (70-140 MPa). The elongation at failure for $\mathrm{Mg}-\mathrm{Zn}-\mathrm{Cu}$ (13\%) and Mg-Zn-Se (12\%) were most comparable to the Mg-3A1-1Z (10-25\%), but lower than annealed Pt-10Ir (20\%). However, the mean elongation for $\mathrm{Mg}-\mathrm{Zn}-\mathrm{Cu}$ and $\mathrm{Mg}-\mathrm{Zn}-\mathrm{Se}(13 \%$ and $12 \%$, respectively) are significantly higher than the elongation values for currently available cast magnesium alloys which range from $2-8 \%$ tensile elongation for non-high pressured diecast methods [20]. Literature suggests that the relative uniformity of critical surface tension for endovascular devices is a primary determinant for the thrombogenicity of implanted stent materials and that tensile elongation itself does not have a significant effect on surface tension [21]. Thus, the high percentages of elongation for $\mathrm{Mg}-\mathrm{Zn}-\mathrm{Se}$ and $\mathrm{Mg}-\mathrm{Zn}-\mathrm{Cu}$ are likely the result of a uniformly distributed surface tension that would be unlikely to result in a thrombogenic surface once implanted. The poisson ratio (v) of $\mathrm{Mg}-\mathrm{Zn}-\mathrm{Se}(0.39)$ and $\mathrm{Mg}-\mathrm{Zn}-\mathrm{Cu}(0.27)$ 
are comparable to both martensitic Nitinol (0.33) and annealed Pt-10Ir (0.38) (Table 3-3). The ratio of both $\mathrm{Mg}-\mathrm{Zn}-\mathrm{Se}$ and $\mathrm{Mg}-\mathrm{Zn}-\mathrm{Cu}$ are below the incompressibility limit of 0.5 , thus the materials retain the longitudinal and transverse elastic flexibility [22].

The fracture analysis of the $\mathrm{Mg}-\mathrm{Zn}-\mathrm{Se}$ alloy and the $\mathrm{Mg}-\mathrm{Zn}-\mathrm{Cu}$ alloy was performed visually by SEM imaging and by energy dispersive X-ray spextroscopy (EDS). Analysis revealed that the Mg-Zn-Se alloy failed transgranularly as evident by the smooth faced fractured surfaces (Fig. 3-3A-D). $\mathrm{Mg}-\mathrm{Zn}-\mathrm{Cu}$ predominantly failed by intergranular failure as seen by the outlined grain structures on the fractured surfaces (Fig. 3-3E-H). The transgranular failure of Mg-Zn-Se is comparable to the transgranular fracture mechanism of the AZ31B alloys which is currently used for stent devices [23]. This mode of failure indicates that the $\mathrm{Mg}-\mathrm{Zn}-\mathrm{Se}$ alloy is more brittle like the AZ31B alloy. Alternatively, the $\mathrm{Mg}-\mathrm{Zn}-\mathrm{Cu}$ alloy undergoes intergranular failure indicating that it is more ductile, which is a more favorable quality in the medical device forming process. Backscatter imaging revealed no separable phases in the fracture surfaces for the $\mathrm{Mg}-\mathrm{Zn}$ Se alloy, whereas two visibly separate phases were evident for $\mathrm{Mg}-\mathrm{Zn}-\mathrm{Cu}$ alloy (Fig. 33F, H). Further EDS analysis on the phases identified them as being primarily composed of $\mathrm{Cu}$ on the faces of the fractured surfaces and along the grain boundaries (Fig. 3-5). This is supported by Zhiyong et al., who proposed that this accumulation of copper along the grain boundary of a high zinc magnesium alloy with copper additions (Mg-10Zn-5Al$0.1 \mathrm{Sb}$ ) is actually the formation of a new $\mathrm{Mg}_{2} \mathrm{Cu}$ phase, which is also a likely formation observed with the $\mathrm{Mg}-\mathrm{Zn}-\mathrm{Cu}$ alloys, although not experimentally confirmed. The localization of the thermally stable $\mathrm{Mg}_{2} \mathrm{Cu}$ phase along the grain boundaries can strengthen the alloy by dispersive strengthening through pinning the movement of 
dislocations and the slip of the $\mathrm{Mg}-\mathrm{Zn}-\mathrm{Cu}$ matrix $[24,25]$. Material manufacturing defects common to occur within the bulk material of the Mg-Zn-Cu and Mg-Zn-Se alloys of some tensile specimens led to premature mechanical failure. $\mathrm{MgO}$ and $\operatorname{Mg}(\mathrm{OH})_{2}$ concentrated regions were detected in $\mathrm{Mg}-\mathrm{Zn}$-Se defective specimens which led to premature tensile failure (Fig. 3-6). This is in accordance with previous literature which found similar oxide formations of $\mathrm{MgO}, \mathrm{Mg}(\mathrm{OH})_{2}$, and $\mathrm{MgCO}_{3}$ within the inner layer of the AZ31 and AZ91 alloy [18]. The casting defect for the $\mathrm{Mg}-\mathrm{Zn}-\mathrm{Cu}$ alloy showed a region with higher concentrations of $\mathrm{MgO}$, but more deplete of $\mathrm{Zn}$ and $\mathrm{Cu}$ as compared to grain boundary concentrations (Fig. 3-7). Regions of such homogenous magnesium concentration and the depletion of $\mathrm{Cu}$ from within the matrix are believed to lead to the deteriorated tensile strength of the $\mathrm{Mg}-\mathrm{Zn}-\mathrm{Cu}$ alloy. The Poisson ratio of both alloys are below the incompressibility limit of 0.5 , hence the alloys possess the longitudinal and transverse elastic flexibility required for manufacturing.

\subsection{Conclusions}

Experimental alloys $\mathrm{Mg}-\mathrm{Zn}-\mathrm{Cu}$ and $\mathrm{Mg}-\mathrm{Zn}-\mathrm{Se}$ show promise for applications as endovascular medical devices as they possess comparable mechanical properties to Nitinol, Pt-10Ir, and the Mg-3A1-1Z alloy. Both experimental alloys possess air formed oxide layer modulus of elasticity values that were greater than the bulk metal alloy values. The oxide layers were determined to be composed of $\mathrm{MgO}, \mathrm{Mg}(\mathrm{OH})_{2}$, and $\mathrm{MgCO}_{3}$ as revealed by XPS analysis which could foreshadow wear, friction, structural changes, and surface-liquid interfacial behavior. $\mathrm{Mg}-\mathrm{Zn}-\mathrm{Cu}$ and $\mathrm{Mg}-\mathrm{Zn}-\mathrm{Se}$ showed favorable tensile elongation at failure values of $13 \%$ and $12 \%$ respectively. These values are higher than any currently cited as-cast magnesium alloys which possess cited 
elongation at failure values of $7-10 \%$ such as the AZ63, AZ81, ZK51, and the WE54 alloy. This higher elongation at failure values produces more tolerable material limits when developing and forming the raw metal into a functional form. Fracture analysis showed that the Mg-Zn-Se alloy failed transgranularly, while the $\mathrm{Mg}-\mathrm{Zn}-\mathrm{Cu}$ alloy fractured by intergranular failure. EDS analysis showed the likely formation of a $\mathrm{Mg}_{2} \mathrm{Cu}$ phase along the grain boundaries of the $\mathrm{Mg}-\mathrm{Zn}-\mathrm{Cu}$ alloy. Elevated $\mathrm{MgO}$ formations and depleted $\mathrm{Mg}-\mathrm{Zn}$ and $\mathrm{Mg}-\mathrm{Cu}$ regions characterized the defective regions of the $\mathrm{Mg}-\mathrm{Zn}-\mathrm{Cu}$ alloy which caused premature failure.

\subsection{References}

1. Persaud-Sharma, D., McGoron, A. Biodegradable magnesium alloys: a review of material development and applications. Journal of Biomimetics, Biomaterials and Tissue Engineering. 2012; 12: 25-39.

2. Saito, S. New horizon of bioabsorbable stent. Catheter Cardiovascular Intervention. 2005; 66: 595-596.

3. Moravej, M., Mantovani, M. Biodegradable metals for cardiovascular stent application: interest and new opportunities. International Journal of Molecular Science. 2011; 12: 4250- 4270.

4. Erne, P., Schier, M., Resink, T.J. The road to bioabsorbable stents: reaching clinical reality? Cardiovascular Interventional Radiology. 2006; 29: 11-16.

5. Colombo, A., Karvouni, E. Biodegradable stents: - fulfilling the mission and stepping away. Circulation. 2000; 102: 371-373.

6. Peuster, M., Wohlsein, P., Brugmann, M., Ehlerding, M., Seidler, K., Fink, C., Brauer, H., Fischer, A., Hausdorf, G. A novel approach to temporary stenting: degradable cardiovascular stents produced from corrodible metal-results 6-18 months after implantation into New Zealand white rabbits. Heart. 2001; 86: 563-569.

7. Oliver, W.C., Pharr, G.M. An improved technique for determining hardness and elastic modulus using load and displacement sensing indentation experiments. Journal of Materials Research. 1992; 7: 1564. 
8. Poncin P, Proft J. Stent Tubing: Understanding the desired attributes. Materials and Processes for Medical Devices conference proceedings. ASM International. 2003.

9. Gupta, M., Nai Mui Ling, S. Magnesium, Magnesium Alloys, and Magnesium Composites: A Guide. John Wiley \& Sons, 2011; 1: 120-150.

10. Johnson Matthey Medical Components. Nitinol Technical Properties. http://jmmedical.com/resources/221/Nitinol-Technical-Properties.html\#nitinoltransformation-properties (November 29, 2012).

11. Kasemo, B., Lausmaa, J. Surface science aspects on inorganic biomaterials. Critical Review of Biocompatibility. 1986; 2: 335-330.

12. Manivasagam, G., Dhinasekaran, D., Rajamanickam, A. Biomedical implants: corrosion and its prevention-a review. Recent Patents on Corrosion Science. 2010; 2: 40-54.

13. Chan, C.M., Trigwell, S., Duerig, T. Oxidation of an NiTi alloy. Surface and interface analysis. 1990; 15: 349-354.

14.Persson, D.H.E., Jacobson, S., Hogmark, S. The influence of phase transformations and oxidation on the galling resistance and low friction behavior of laser processed Co-based alloy. Wear. 2003; 254: 1134-1140.

15. Meyers, M., Chawla, K. Mechanical Behaviors of Materials. CRC Press, 1999; $2^{\text {nd }}$ Edition: 162-168.

16. Persaud-Sharma, D., Munroe, N., McGoron, A. Electro and magneto-electropolished surface micro-patterning on binary and ternary Nitinol. Trends in Biomaterials and Artifical Organs. 2012; 26: 74-85.

17. Stauss, S., Schwaller, P., Bucaille, J.-L., Rabe, R., Rohr, L., Michler, J., Blank, E. Determining the stress-strain behavior of small devices by nanoindentation in combination with inverse methods. Microelectronic Engineering. 2003; 67-68: $818-825$.

187. Wang, L., Shinohara, T., Zhang, B.P. XPS study of the surface chemistry on AZ31and AZ91 magnesium alloys in dilute $\mathrm{NaCl}$ solution. Applied Surface Science. 2010; 256: 5807-5812.

19. Revie, R.W., Uhlig, H.H. Corrosion and corrosion control: an introduction to corrosion science and engineering. John Wiley and Sons, 2008; 4: 125-165.

20. Grote, K.H., Antonsson, E. Handbook of Mechanical Engineering. Springer, 2010; 10: $530-540$. 
21. Shrivastava, S. Medical device materials: proceedings from the materials $\&$ processes for medical devices. ASM International, California, 2003; 69-74.

22. Liu, B., Zhang, L., Gao, H. Poisson ratio can play an important role in mechanical properties of biocomposites. Mechanics of Materials. 2006; 38: 1128-1142.

23. Zhang, H., Wang, W., Wei, Y., Li, J., Wang, J. Fatigue fracture mechanism of AZ31B magnesium alloy and its welded joint. Transactions of Nonferrous Metals Society of China. 2011; 21: 1225-1233.

24. Zhiyong, Y., Yuhua, Z., Weili, C., Jinshan, Z., Yinghui, W. Effect of Cu addition on microstructure and properties of Mg-10Zn-5Al-0.1Sb high zinc magnesium alloy. China Foundry. 2012; 9: 43-47.

25. Chen, Z. Heat-resistant magnesium . Chemical Industry Press, China. 2006; 109-115. 


\section{CHAPTER 4 \\ BIOCOMPATIBILITY ASSESSMENT OF NOVEL BIORESORBABLE ALLOYS \\ $\mathrm{Mg}-\mathrm{Zn}-\mathrm{Cu}$ and $\mathrm{Mg}-\mathrm{Zn}-\mathrm{Se}$}

\subsection{Introduction}

One of the attractive features of biodegradable materials is their ability to serve as a temporary scaffold for biological tissue growth and degrade thereafter [1]. This degradable feature is highly desired because it minimizes the need for repeated corrective post-surgical procedures which increases the likelihood of patient complications. Currently, several metallic and polymeric materials possess a degradative quality suitable for a biodegradable device. For example magnesium alloys $\mathrm{Mg}-\mathrm{Zn}, \mathrm{Mg}-\mathrm{Zn}-\mathrm{Al}, \mathrm{Mg}-\mathrm{Zn}-$ $\mathrm{Zr}, \mathrm{Mg}-\mathrm{Zn}-\mathrm{Ca}$, iron alloys $\mathrm{Fe}-\mathrm{Mn}$, and $\mathrm{Fe}-\mathrm{Mn}-\mathrm{Si}$, and polymeric materials like (co)polyesters from aliphatic hydroxyl acids (PHAs), polyglycolide (PGA), and poly(lactide-co-glycolide) (PLGA) have been shown to be suitable for these applications [2-5]. However, the widespread application of these materials is inhibited by inherent challenges for each material, such as controlling and profiling degradation kinetics for magnesium and iron alloys, and polymeric materials [6]. Polymeric materials were originally desirable; however, they have yet to overcome the challenges of producing repeatable and accurate degradation kinetic profiles, long-term performance integrity, minimizing host immune responses, and costly time-intensive research and development $[5,6]$.

Previous attempts at developing magnesium alloys for these applications include Mg-Zn, Mg-3Al-1Z, and Mg-Zn-Zr. The inclusion of ternary elements ' $\mathrm{Zr}$ ' and 'Al' to binary $\mathrm{Mg}-\mathrm{Zn}$ was made in attempts to control the corrosion rate of the alloys, improve alloy strength and refine grain structure $[7,8]$. However, a major downfall of these alloy 
compositions is that the alloying elements have no functional role within the body and are not entirely absorbable by endogenous tissues [9]. Furthermore, the degradation products of such alloys contain elements that have no functional role within the body and could impose significant complications to the human excretory system once implanted in-vivo.

The study presented in this paper explores novel $\mathrm{Mg}-\mathrm{Zn}-\mathrm{Se}$ and $\mathrm{Mg}-\mathrm{Zn}-\mathrm{Cu}$ degradable alloys with the inclusion of biologically essential trace minerals, selenium and copper. It is expected that since the degradation products are composed of elements that have a functional role within the body, it would result in total material reabsorption and use by biological and enzymatic processes. Previous studies have extensively shown that selenium has an important role in fighting free oxidative radicals within the body, reducing viral expressions, preventing heart disease, and plays an important role in muscle formation $[10,11]$. Additionally, copper has been utilized to treat diseases since the ancient society of Hippocrates 400 B.C. [12]. Copper also has several roles as a cofactor for essential enzymatic processes within the body, like cytochrome 'c' oxidase, superoxide dismutase, feroxidase, and peptidylglycine monooxygensase, amongst others [13]. It is believed that the inclusion of $\mathrm{Se}$ and $\mathrm{Cu}$ elements to form novel magnesium alloys will result in alloys with more favorable degradation kinetics required for endovascular use and wound healing properties that can promote neo-intimal growth. It has previously been shown by Persaud-Sharma et al., that these magnesium alloys possess improved mechanical properties when compared to other as-cast magnesium alloys such as $\mathrm{Mg}-3 \mathrm{~A} 1-1 \mathrm{Z}$, and martensitic Nitinol [14]. The trace element of $\mathrm{Cu}$ has been shown to have harmful effects on living tissues; however, its role is vital for maintaining proper metabolic and neurological function [15]. Thus, the inclusion of only 
$1 \mathrm{wt} . \%$ of copper and $1 \mathrm{wt} . \%$ selenium in the design of the alloy compositions was to assess the gross property differences of the alloys when compared to a binary $\mathrm{Mg}-\mathrm{Zn}$ alloy without ternary elements $\mathrm{Cu}$ and $\mathrm{Se}$.

In this study, the biocompatibility of experimental alloys $\mathrm{Mg}-\mathrm{Zn}-(1)-\mathrm{Cu}(1) \mathrm{wt} . \%$ and Mg-Zn-(1)-Se-(1) wt.\% is qualitatively and quantitatively assessed. Cytotoxicity effects of major degradation products are measured when used to culture human foreskin fibroblast cells in-vitro. Attempts at characterizing cell-surface interactions were made using scanning electron microscopy (SEM) techniques. Lactate dehydrogenase concentrations were measured to quantify cell death after the cells were in direct contact with the experimental magnesium alloys for a 72-hour period.

\subsection{Materials and Methods}

\subsubsection{Alloy Manufacturing and Sample Preparation}

The alloy compositions were synthesized using an arc-melting method in inert argon gas by ACI Alloys, Inc. (CA, USA). Both alloy compositions were composed of wt.\% ratios (98/1/1) Mg-Zn-Se/Cu as seen in Table I. Square samples were then cut from a 1" x 1" x 6" cast mold bar of each alloy. 
Table 4-1. Weight Percentage of Alloy Compositions (wt.\%)

\begin{tabular}{|c|c|c|c|c|}
\hline Alloy Composition & Mg & Zn & Cu & Se \\
\hline Mg-Zn (98/01) & 99 & 1 & - & - \\
\hline Mg-Zn-Se (98/01/01) & 98 & 1 & - & 1 \\
\hline Mg-Zn-Cu (98/01/01) & 98 & 1 & 1 & - \\
\hline
\end{tabular}

Square testing specimens with an average dimension of $10 \mathrm{~mm}$ x $10 \mathrm{~mm} \times 0.94 \mathrm{~mm}$, were then mechanically dry ground to a \#1200 grit finish using silicon carbide abrasive paper. After mechanical polishing, samples were cleaned in acetone and rinsed with deionized water and blown dry with nitrogen gas. Materials were stored in a plastic container until further testing. Before any biological testing, all experimental alloy specimens were sterilized using an AMSCO Century Steris SV-120 pre-vacuum sterilizer at Gravity 20.

\subsubsection{Alloy Sample Surface Characterization}

The surface roughness of all alloy samples used in biological testing was characterized using a Veeco Instruments Wyko NT 9100 white-light profilometer system using the non-contact vertical scanning interferometry (VSI) measurement mode. $640 \mathrm{x}$ 480 array size dimensions were used to quantify surface roughness using reported ' $\mathrm{Ra}$ ' values. Optical profilometry equipment was used at the Nanotechnology Research Institute at the University of South Florida (Tampa, FL, USA).

Contact angle measurements using sessile drop methodology were made using a KSV contact angle goniometer with CAM 101 analysis software. The averages of the left and right contact angles were used to determine a mean contact angle value $(\Theta)$ used for surface energy calculations. Free surface energy or critical surface tensions of each alloy 
was calculated according to Zisman according to the Young Equation as shown in Equation 1. The $\gamma_{\mathrm{SG}}, \gamma_{\mathrm{SL}}$ and $\gamma_{\mathrm{LG}}$ are the surface tensions of interfaces between solid/gas, solid/liquid and liquid/gas, respectively. The contact angle, denoted as $(\Theta)$, is the angle between the liquid drop and a solid surface.

$$
\gamma_{\mathrm{SG}}=\gamma_{\mathrm{SL}}+\gamma_{\mathrm{LG}} \cos (\theta)
$$

For this testing, deionized water and ethylene glycol were used as the two liquid probes. Contact angle equipment was used at the Center for Drug Discovery and Innovation at the University of South Florida (Tampa, FL, USA).

\subsubsection{MTS Assay}

A cell proliferation MTS assay (G5421, Promega Corporation) was used to determine the percentage of viable human foreskin fibroblast cells grown in extract solutions of varying concentrations. To achieve this, $\mathrm{Mg}-\mathrm{Zn}-\mathrm{Se}, \mathrm{Mg}-\mathrm{Zn}-\mathrm{Cu}$, and $\mathrm{Mg}-\mathrm{Zn}$ alloys were immersed in $300 \mathrm{~mL}$ of Hyclone's Dulbecco's Modified Eagles Medium (DMEM) without fetal bovine serum for 30 -days at $37^{\circ} \mathrm{C}$ with constant shaking. This method is conventionally used in the biomedical industry to obtain an extract solution in which the major toxic leachables from the material being tested is collected in a useable solution. In my opinion, this process simulates the short-term effects of material degradation under dynamic conditions similar to what exists in the human cardiovascular system. The extract solution was filter sterilized using a $0.2 \mu \mathrm{m}$ IC-Millex syringe filter with a hydrophilic PTFE millipore membrane to eliminate non-sterile contaminants. Initial cell media solutions were made using concentrated $100 \%$ extract, and a 50/50 
solution composed of $50 \%$ extract with $50 \%$ fresh cell growth medium. Cells were grown in the $100 \%$ and $50 / 50$ extract solution for a period of 72 hours. After initial results showed that the percentage of cell growth was low (33\%) when cultured in the Mg-Zn$\mathrm{Cu} 100 \%$ extract solution, but high (93\%) when cultured in the 50/50 diluted $\mathrm{Mg}-\mathrm{Zn}-\mathrm{Cu}$ extract solution, subsequent testing to identify the toxic extract concentration between the $50 \%$ dilution and $100 \%$ extract was performed (i.e., $65 \%$ and $85 \%$ ). For these experiments fibroblast cells were grown for a 7 day period with media being changed every 72 hours.

Human foreskin fibroblast cells (Global Stem ${ }^{\circledR}$ ) were plated with a density of 3.3 x $10^{3}$ cells/well into a 96 -well micrometer plate. The plates were incubated for 24 hours at $37^{\circ} \mathrm{C}$ in a humidified atmosphere of $5 \% \mathrm{CO}_{2}$ in air. Cells were counted before plating using a Bright-line hemacytometer. After the 24 hour incubation period, the $100 \%$ culture medium was replaced with the varying concentrations of the extract dilutions using pure culture medium (blank) without cells and pure culture medium with cells as the control groups. After 72 hours of incubation from the exposure to the extract solutions without changing media, the cell culture was treated with $20 \mu \mathrm{L} /$ well of the combined MTS/PMS solution. The cells with the MTS assay treatment were further incubated for an additional 4 hours at $37^{\circ} \mathrm{C}$ in a humidified atmosphere of $5 \%$ of $\mathrm{CO}_{2}$. Immediately after 4 hours, absorbance measurements were made using a Tecan GeniOS instrument using Magellan software. Absorbance and excitation filters used were $470 \mathrm{~nm}$ and $690 \mathrm{~nm}$, respectively. All material extracts were tested in 6 replicates for each extract concentration for 4 separate experiments with comparable results. 


\subsubsection{Fluorescent Imaging}

To observe morphological changes to the cells and apoptosis or necrosis, the cells were fluorescently stained using Calcein-AM $5 \mathrm{mM}$ in dimethyl sulfoxide (DMSO) (Molecular Probes) and propidium iodide $1 \mathrm{mg} / \mathrm{mL}$ (Sigma-Aldrich). Imaging was recorded using a Nikon Eclipse TE-2000E microscope using a 10x objective and pseudocolored using EZ-C1 software. Green cells were interpreted as being viable, dead cells were stained red, and apoptotic cells were imaged as yellow.

\subsubsection{LDH Quantification}

Human Foreskin Fibroblast cells were seeded at a density of $2.5 \times 10^{4}$ cells/well in a 24-well plate with culture medium (Hyclone DMEM, 5\% Penicillin, 10\% FBS). The cells were incubated for 24 hours at $37^{\circ} \mathrm{C}$ in a humidified atmosphere of $5 \% \mathrm{CO}_{2}$. Samples of each alloy possessed an average surface area of $1.1 \mathrm{~cm}^{2}$ and a thickness of $0.105 \mathrm{~cm}$. The average growth area per well in a $24-w e l l$ plate is $1.9 \mathrm{~cm}^{2}$. Thus, each alloy specimen covered an average of $58 \%$ of the available growth area. After the 24hour period of cell incubation, the alloy specimens were placed on the surface of the adherent fibroblast cells. The cells were then incubated for 72 hours without refreshing the culture medium. After each 24 hour period (day1, day2, day3), the LDH concentration from each well containing cells was quantified using a Promega membrane integrity assay (G7890, Promega Corporation).

More specifically, after each 24 hour period, the plates were centrifuged for 4 minutes using an Eppendorf Vacuufuge vacuum concentrator with an orbital speed of $1400 \mathrm{rpm}(250 \mathrm{x} \mathrm{g})$. This was done to eliminate any contaminant particles resulting from 
cell lysis as a result of exposure to the experimental alloys. Subsequently, supernatant aliquots of $50 \mu \mathrm{L}$ were transferred to a sterile black-bottom 96 -well plate. $50 \mu \mathrm{L}$ of the CytoTox reagent was then added to each $50 \mu \mathrm{L}$ of experimental aliquot solution, bringing the total volume per well to $100 \mu \mathrm{L}$. Afterwards, the well plate was then left unexposed to light at room temperature for 10 minutes. Immediately after 10 minutes, the fluorescence (in relative fluorescent units, RFU) was recorded using a Tecan GeniOS plate reader with Magellan software using $555 \mathrm{~nm}$ and $590 \mathrm{~nm}$ excitation and emission filters, respectively. Wells containing pure culture media without cells and wells containing cells and pure culture media were used as controls. After each 24 hour period, lysis solution was added to control wells to obtain maximum LDH concentration values so that cytotoxicity percentages could be calculated.

\subsubsection{Direct Contact Assay}

Following the protocol stated above, human foreskin fibroblast cells were seeded at a density of $2.5 \times 10^{4}$ cells/well in 24-well plate with culture medium (Hyclone DMEM, 5\% Penicillin, 10\% FBS) containing the experimental alloys. This was done to characterize any cellular morphological changes from being in direct contact with the experimental alloys as well as to determine their cellular adhesion potential. Once the cells were seeded on the experimental alloys, cellular growth was monitored for 3 days (72-hours) at $37^{\circ} \mathrm{C}$ in a humidified atmosphere of $5 \% \mathrm{CO}_{2}$. After the 72 hour period of growth, the samples were observed by scanning electron microscopy (SEM). The dimension of each alloy sample was tailored to cover $58 \%$ of the available growth area. 


\subsubsection{SEM Imaging Preparation}

Cells were grown for 72-hours in contact with the experimental alloys as described in the direct contact assay section. After the 72-hour period of growth, the surface of the experimental alloys were washed with PBS and fixed with $2.5 \%$ glutaraldehyde in $0.1 \mathrm{M}$ phosphate buffer for 45 minutes at $4{ }^{\circ} \mathrm{C}$. After the fixation, the cells were washed for 10 minutes for each increasing concentration of ethanol $(50 \%$, $70 \%, 90 \%$ and $100 \%$ ) to remove all water content from the specimens. The materials with the adherent cells were kept in $100 \%$ ethanol until being subjected to critical point drying (CPD) to avoid water contamination (Samdri-PVT-3D Tousimis). The samples were then coated with Au-Pd using a sputter coater (SPI Module). Lastly, secondary electron images (SEI) of the samples were obtained using a JEOL JSM 5900 LV SEM with an EDS-UTW Detector.

\subsubsection{Statistical Analysis}

A multi-variable ANOVA test was conducted to assess whether there was any significant difference between the measurement parameters of surface roughness, contact angles values, liquid probe used for contact angle measurements (DI water, ethylene glycol), surface energy, cell viability percentages as determined by using the MTS Assay, and cytotoxicity results from the LDH assay for each alloy composition. Differences with p-values less than 0.05 were considered significant. This was followed by a post-hoc assessment using Fisher's least significant difference method. Additionally, Spearman’s nonparametric correlation test was performed to evaluate the relationship between the tested variables and each alloy composition. Correlation was determined to be significant 
at both the 0.01 and 0.05 levels. Correlation analysis showed a significant positive correlation $\left(r_{s}=0.830\right)$ between liquid probe used (water and ethylene glycol) and contact angle formed. A negative correlation was found between the surface roughness parameter and the contact angle formed using ethylene glycol as a liquid probe $\left(r_{s}=-\right.$ $0.283)$.

\subsection{Results}

\subsubsection{Surface Properties of Ternary Magnesium Alloys}

Table 4-2 summarizes the surface properties of the tested experimental ternary magnesium alloys. The average surface roughness values were not statistically different; however, the Mg-Zn alloy showed a higher mean surface roughness of $158 \mathrm{~nm}$ as compared to $\mathrm{Mg}-\mathrm{Zn}-\mathrm{Se}$ and $\mathrm{Mg}-\mathrm{Zn}-\mathrm{Cu}$. Average contact angles values (Left \& Right) for all samples were also very similar with mean values ranging from $70-77^{\circ}$ for ethylene glycol measurements and $59-62^{\circ}$ for DI water. Although not reaching differences of statistical significance, the Mg-Zn alloy that had the highest mean surface roughness was also shown to have the highest mean contact angle values of $77^{\circ}$ when using ethylene glycol as the liquid probe, and the lowest mean contact angle of $59^{\circ}$ when using DI water as the liquid probe. Surface energy calculations showed that $\mathrm{Mg}-\mathrm{Zn}-\mathrm{Se}$ had the highest mean critical surface tension of $70 \mathrm{mN} / \mathrm{m}$, while $\mathrm{Mg}-\mathrm{Zn}$ had the lowest mean critical surface tension of $57 \mathrm{mN} / \mathrm{m}$. Differences in surface energy values did not reach statistical significance. 
Table 4-2. Surface Properties of Ternary Magnesium Alloys

Data represented as mean \pm standard deviation; $N=15$ (\# of samples), $\mathrm{n}=2$ (\#of repeated measurements per samples). Data among groups were not statistically different.

\begin{tabular}{|c|c|c|c|c|}
\hline $\begin{array}{l}\text { Alloy } \\
\text { Composition }\end{array}$ & $\begin{array}{l}\text { 3-Dimensional Optical Profilometry Image of the } \\
\text { Alloy Surface }\end{array}$ & $\begin{array}{c}\text { Average } \\
\text { Surface } \\
\text { Roughness } \\
(\mathrm{nm})\end{array}$ & $\begin{array}{c}\text { Average } \\
\text { (Left \& } \\
\text { Right) } \\
\text { Contact } \\
\text { Angle } \\
\text { Values (०) } \\
\text { Ethylene Glycol } \\
\text { DI Water }\end{array}$ & $\begin{array}{c}\text { Zisman } \\
\text { Surface } \\
\text { Energy } \\
\gamma_{c} \\
(\mathrm{mN} / \mathrm{m})\end{array}$ \\
\hline$M g-Z n$ & & $158 \pm 71$ & $\begin{array}{c}77 \pm 5 \\
59 \pm 1.8\end{array}$ & $57 \pm 35$ \\
\hline $\mathrm{Mg}-\mathrm{Zn}-\mathrm{Se}$ & & $145 \pm 107$ & $\begin{array}{c}76 \pm 6 \\
60 \pm 1.9\end{array}$ & $70 \pm 24$ \\
\hline
\end{tabular}




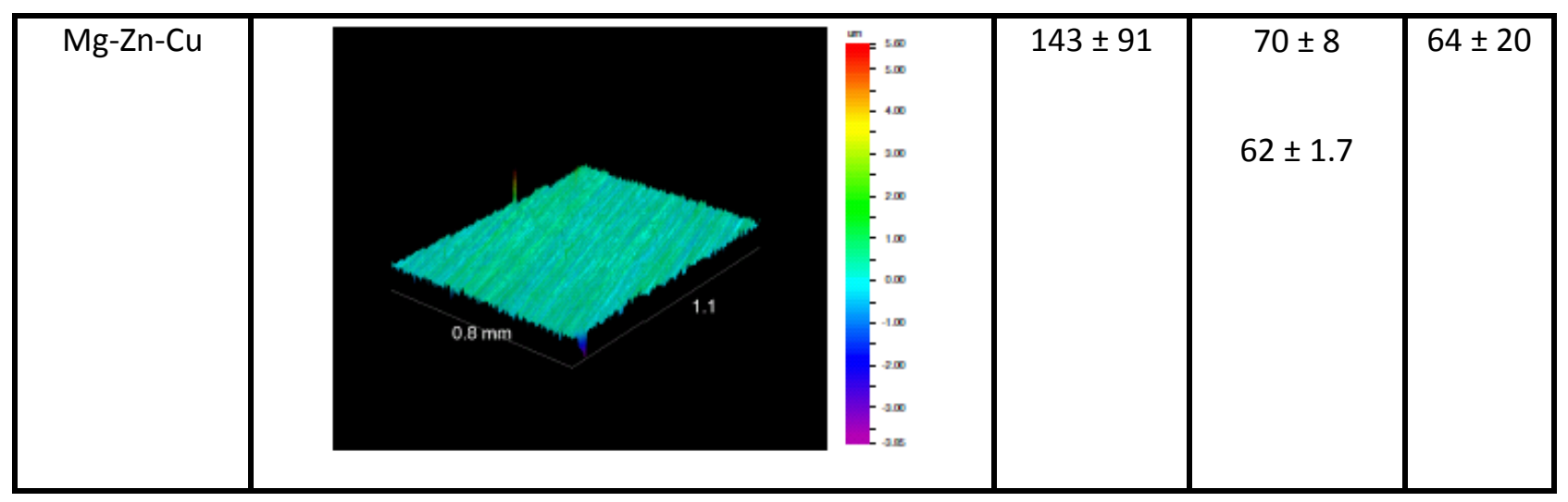

\subsubsection{Cell Viability: MTS Assay}

The MTS assay results are represented in Figure 4-1. It was observed that cells maintained $100 \%$ cell growth when cultured in 50/50 extract solution from the $\mathrm{Mg}-\mathrm{Zn}$ and $\mathrm{Mg}-\mathrm{Zn}-\mathrm{Se}$ alloys, while the cells cultured in the $\mathrm{Mg}-\mathrm{Zn}-\mathrm{Cu}$ alloy extract yielded the lowest percentage of cell growth of $93 \%$ at day 3. Additionally, the $\mathrm{Mg}-\mathrm{Zn}-\mathrm{Cu}$ alloy showed the lowest percentage of cell growth of $33 \%$ when cultured in the $100 \%$ extract solution. No statistical difference in percentage of cell growth for cells cultured in the $100 \%$ and 50/50 extract solutions obtained from the $\mathrm{Mg}-\mathrm{Zn}$ and $\mathrm{Mg}-\mathrm{Zn}-\mathrm{Se}$ alloys was observed. 


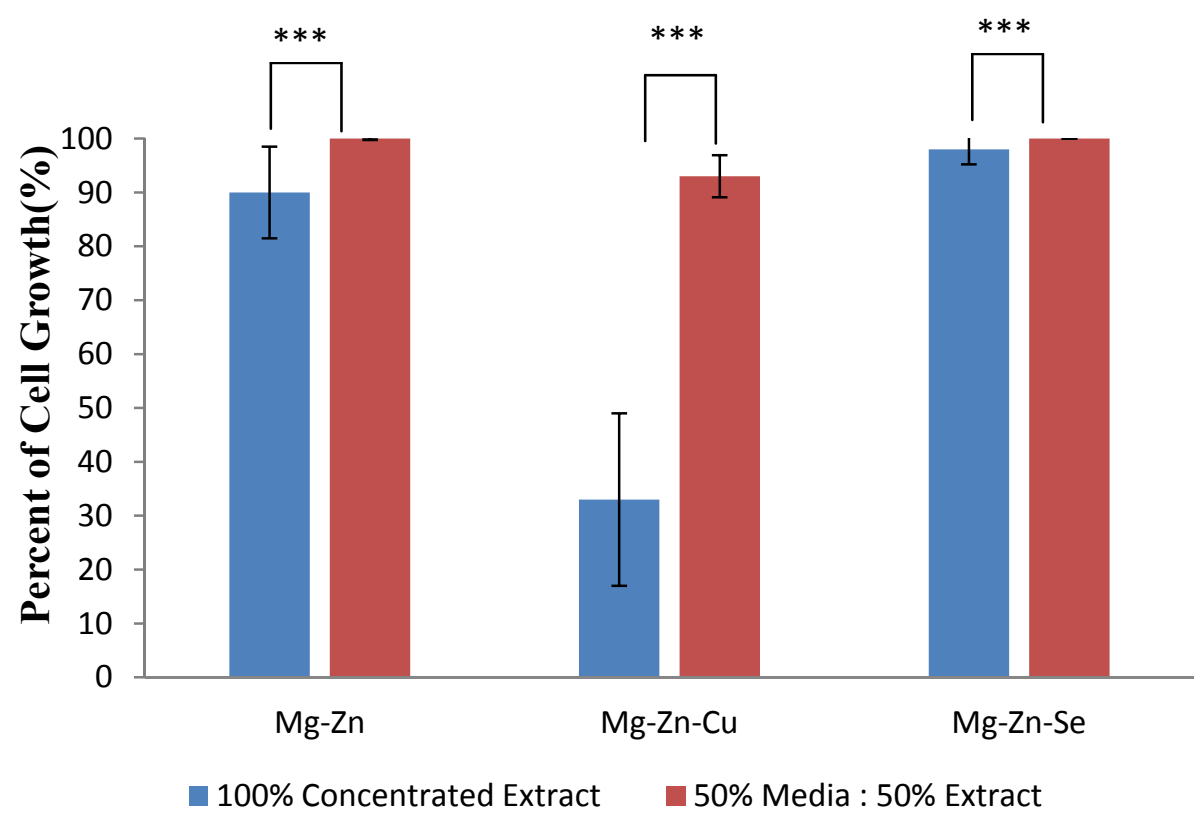

Figure 4-1. Percent of cell growth of human foreskin fibroblast cells when cultured in $100 \%$ concentrated 30 - day extract and $50 / 50 \%$ diluted 30-day extract after 3-days of growth. Results collected using an MTS assay, and cell growth was measured relative to a control where the fibroblast cells were grown in $100 \%$ media. Data represented as mean with Std. Dev. Bars; $\mathrm{N}=4$ (sample size), $\mathrm{n}=3$ (repeated measurements per sample). ${ }^{* * *}$ Statistical difference $(\mathrm{p}<0.05)$.

Noting the low percentage of cell growth of fibroblast cells when cultured in the $100 \%$ extract obtained from the $\mathrm{Mg}-\mathrm{Zn}-\mathrm{Cu}$ alloy, further testing was performed to narrow the range of cytotoxicity between the 50/50 and $100 \%$ extract solution. Thus, cells were cultured in $65 \%$ and $85 \%$ extract concentrations for an extended period of 7 days. 


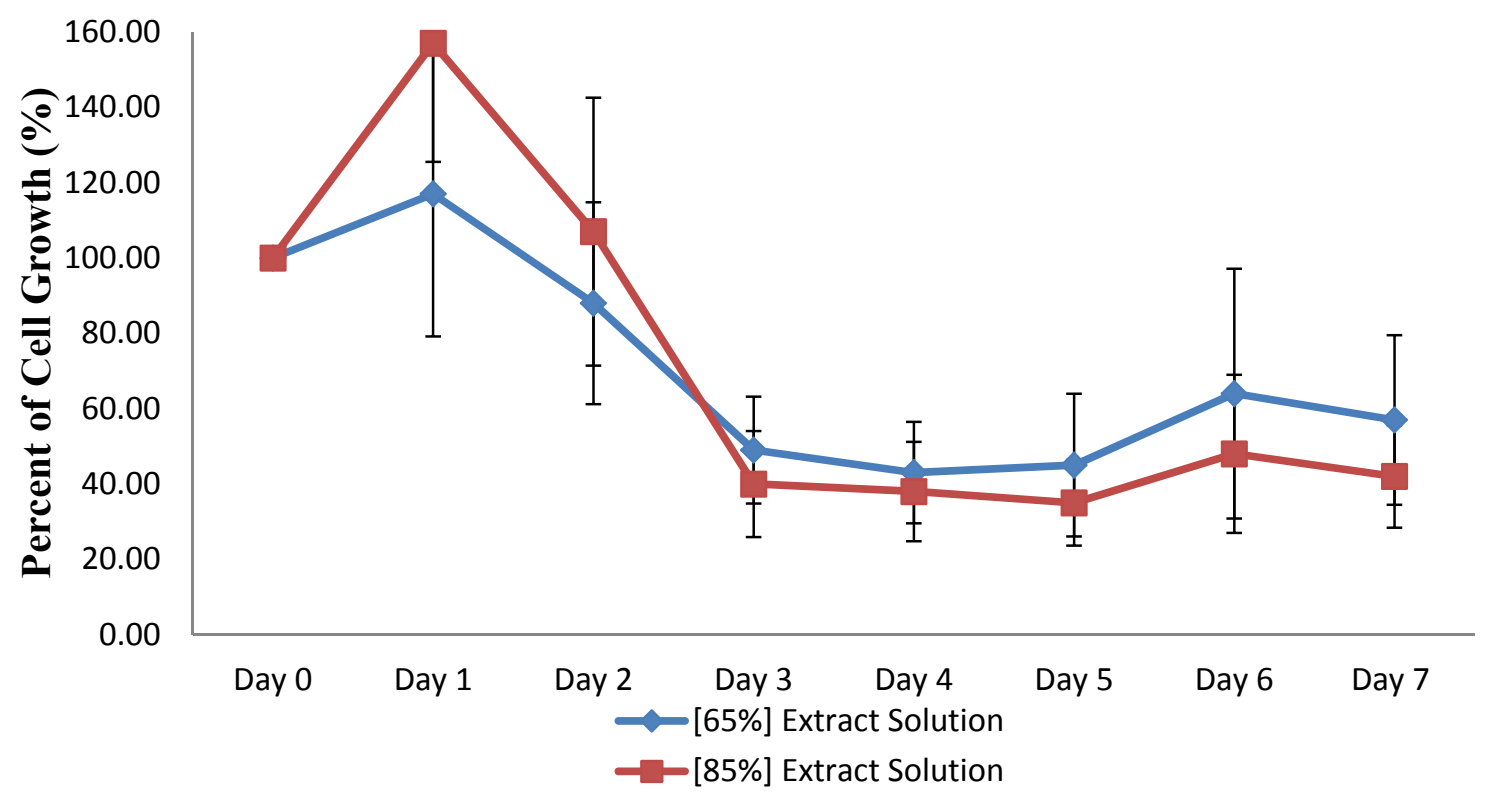

Figure 4-2. Percent of cell growth of human foreskin fibroblast cells when cultured in $65 \%$ and $85 \%$ 30-day extract after 7 days. Results collected using an MTS assay, and cell growth was measured relative to a control where the fibroblast cells were grown in $100 \%$ media. Data represented as mean with Std. Dev. Bars; $N=4$ (sample size), $n=3$ (repeated measurement per sample). Cell growth/death was not statistically different between extract concentration solutions per day. Cell growth/death was significantly different relative to day 0 .

Notably, there were a higher number of cells after the first day compared to the initial cell seeding density for both the $85 \%$ and $65 \%$ extract solutions of the $\mathrm{Mg}-\mathrm{Zn}-\mathrm{Cu}$ alloy with percentage of cell growth reaching $157 \%$ and $117 \%$ for each extract concentration, respectively. After the second day of growth, the percentage of cell growth remained high in the $85 \%$ concentrated extract solution though decreasing from $157 \%$ to $107 \%$, whereas the percentage of cell growth in the $65 \%$ extract-solution decreased from $117 \%$ to $88 \%$. Days 3, 4 , and 5 showed the lowest percentage of cell growth $(35-40 \%)$ when cultured in both extracts concentrations. Expectedly, the percentage of cell growth viability remained slightly higher in the $65 \%$ concentrated extract solution than in the $85 \%$ concentrated solution for days 3,4 and 5 because of the lower concentration of $\mathrm{Cu}$ 
in the $65 \%$ extract solution. Major cytotoxic effects were seen on day 3 of the cell growth period. Conclusively, extract concentrations ranging from $65 \%-100 \%$ was identified as inducing the most cytotoxic effect. Figure 4-3, shows a comparison of viable cells cultured in $100 \%$ extract media and diluted $50 \%$ extract media.
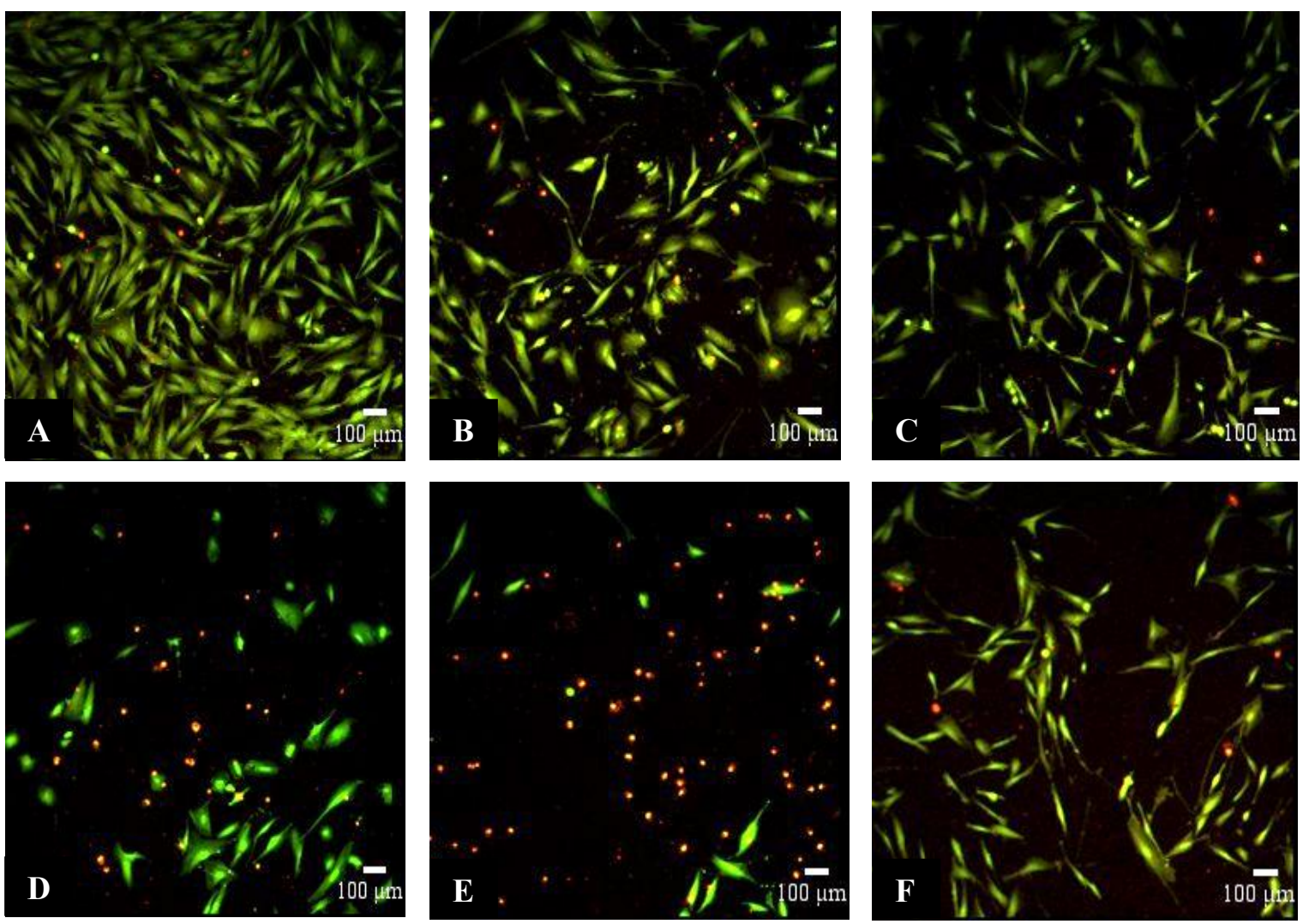

Figure 4-3. Human foreskin fibroblast cells cultured for 72 hours in diluted and pure 30day extract solutions from the MTS Assay. Images after 72 hour growth period: A (Mg$\mathrm{Zn}$ ), B (Mg-Zn-Cu), C (Mg-Zn-Se) are cultured in 50\% media: $50 \%$ extract solutions. $\mathrm{D}(\mathrm{Mg}-\mathrm{Zn}), \mathrm{E}(\mathrm{Mg}-\mathrm{Zn}-\mathrm{Cu}), \mathrm{F}(\mathrm{Mg}-\mathrm{Zn}-\mathrm{Se})$ are cultured in $100 \%$ concentrated 30-day extract solution. Viable cells are stained green, while dead cells are stained red.

Figure 4-3A, B, C all show a high percentage of viable cells using fluorescence microscopy. Viable cells appeared fluorescent green (Calcein-AM) for fibroblast cells grown in 50/50 culture medium for $\mathrm{Mg}-\mathrm{Zn}, \mathrm{Mg}-\mathrm{Zn}-\mathrm{Cu}$, and $\mathrm{Mg}-\mathrm{Zn}-\mathrm{Se}$ alloys, 
respectively. Figure $3 \mathrm{D}, \mathrm{E}, \mathrm{F}$ show lower percentages of viable cells (green) and more dead cells (red-PI) as these images correspond to cell growth in $100 \%$ pure extract solutions. Most notably with Figure 4-3E possessing the most dead cells ( $\mathrm{Mg}-\mathrm{Zn}-\mathrm{Cu}$ ).

\subsubsection{Percent Cytotoxicity: LDH Quantification, Direct Contact Assay, and Cellular Adhesion}

Figure 4-4, shows the cytotoxicity of human foreskin fibroblast cells cultured in direct contact with the Mg-Zn and the Mg-Zn-Se alloy for 3 days of growth without changing cell culture media. For all three days of growth, cytotoxicity was lower for the $\mathrm{Mg}-\mathrm{Zn}$-Se alloy with a mean cytotoxicity percentage of $22 \%$ on day 1 , and a mean cytotoxicity percentage of $31 \%$ and $34 \%$ on days 2 and 3, respectively. Mg-Zn showed a slightly higher percentage of cytotoxicity of 26,35 and 36 percent on days 1, 2, and 3 , respectively. LDH concentrations could not be quantified for the $\mathrm{Mg}-\mathrm{Zn}-\mathrm{Cu}$ alloy because the alloy specimens for such a composition completely degraded within the 72 hour time period causing all of the cells to die. 


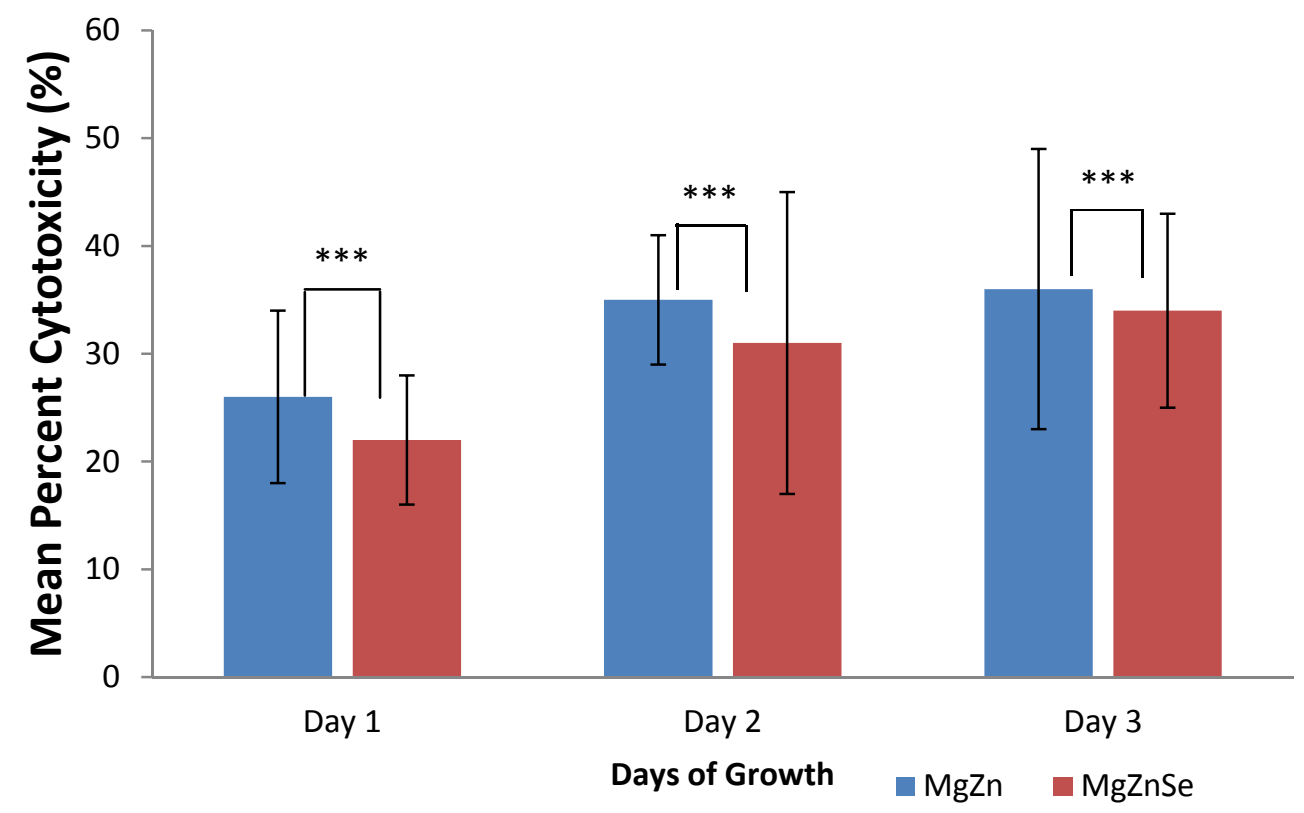

Figure 4-4. Percent cytotoxicity of human foreskin fibroblast cells seeded on Mg-Zn and Mg-Zn-Se alloys measured by LDH quantification over a 3 day period of exposure. Data represented as mean with Std. Dev. Bars; $N=4$ (sample size), $\mathrm{n}=3$ (repeated measurements per sample). ${ }^{* * *}$ Statistical difference $(p<0.05)$.

Surface images of the Mg-Zn and Mg-Zn-Se alloys were taken before and after the 72 hour period of growth to measure cell adhesion and characterize morphology changes. Figure 4-5A shows the Mg-Zn surface before cell exposure, while Figure 4-5D shows the same specimen after experimental exposure and SEM sample preparation. Likewise, Figures 4-5B and 4-5E show the Mg-Zn-Se alloy surface both before and after experimentation. It can be seen for both surfaces that after the experimental period of cell growth no surface cellular adhesion is evident. Visually, the surfaces after experimentation and SEM sample preparation for imaging are coarser, have an increased surface roughness, and have more defined grain boundaries. 

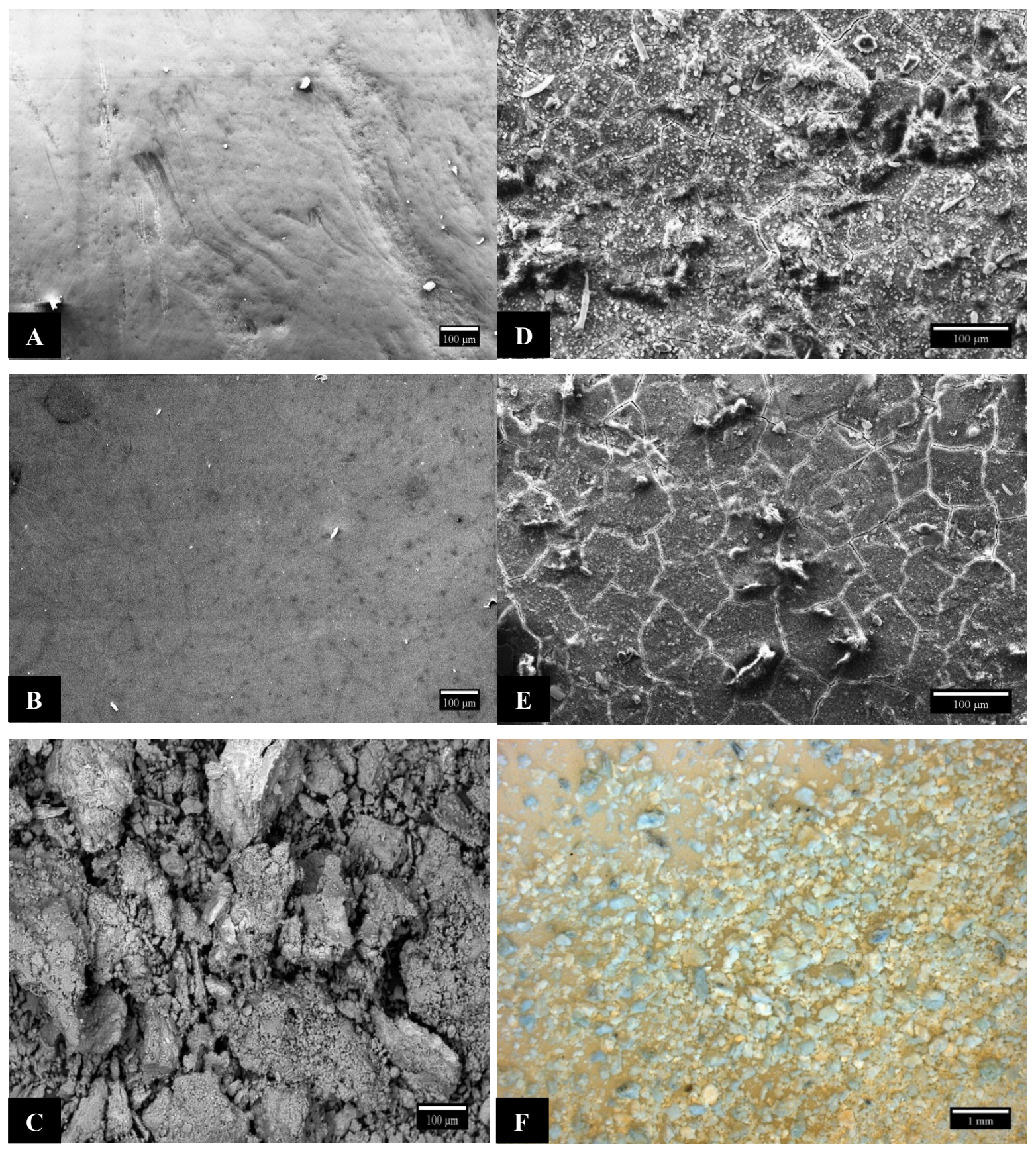

Figure 4-5. Scanning electron microscopy (secondary electron image) surface images of $\mathrm{Mg}-\mathrm{Zn}$ and $\mathrm{Mg}-\mathrm{Zn}-\mathrm{Se}$ before and after exposure to cell growth duration of 72 hours and precipitate formation from the degradation of the $\mathrm{Mg}-\mathrm{Zn}-\mathrm{Cu}$ alloy. Surface images before/after experimentation: A/D) Mg-Zn showing no cell adhesion, B/E) Mg-Zn-Se showing no cell adhesion. C) SEM image of precipitate formation of $\mathrm{Mg}-\mathrm{Zn}-\mathrm{Cu}$. F) Optical image with the true color of precipitate formation of $\mathrm{Mg}-\mathrm{Zn}-\mathrm{Cu}$. 
Within the 72 hour experimental period of cell growth, all $\mathrm{Mg}-\mathrm{Zn}-\mathrm{Cu}$ alloy samples with an average weight of $0.285 \mathrm{~g}$ completely degraded forming a white precipitate; thus, negating any cell growth, cell adhesion, and LDH quantification. A true color optical image of the precipitate that resulted from the degradation of $\mathrm{Mg}-\mathrm{Zn}-\mathrm{Cu}$ in the DMEM culture medium with human foreskin fibroblast cells is seen in Figure 4-5F. Backscatter SEM images of the same precipitate is seen in Figure 4-5C. Characteristically, white deposits are visible on the surface of these alloys, with pronounced grain boundaries after the 72-hour period. Energy dispersive X-ray spectroscopy (EDS) was performed to chemically identify the composition of the artifacts shown in Figure 4-6.

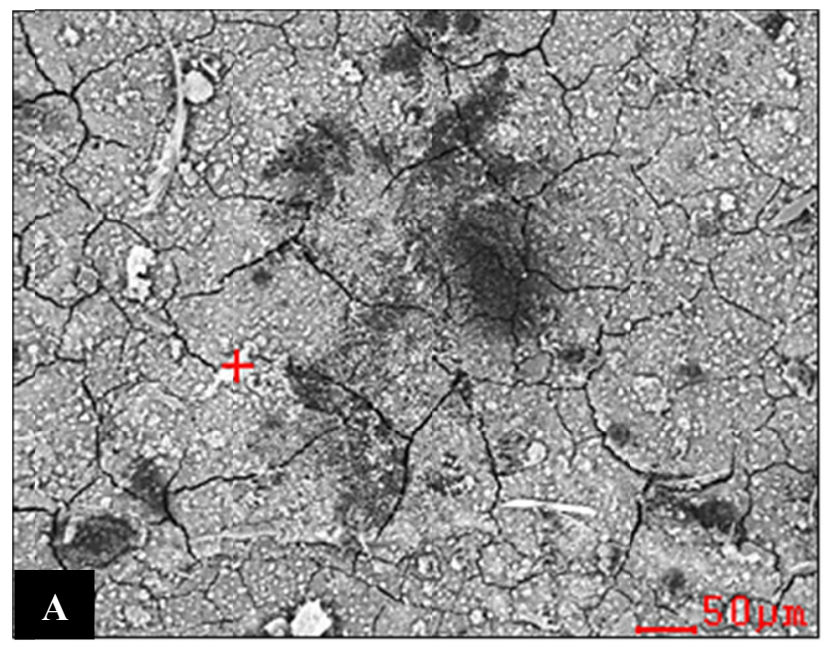

\begin{tabular}{c|c|c}
\hline Element & Wt.\% & At.\% \\
\hline $\mathrm{C}$ & 23.92 & 35.69 \\
\hline $\mathrm{O}$ & 35.49 & 39.77 \\
\hline $\mathrm{Na}$ & 1.71 & 1.33 \\
\hline $\mathrm{Mg}$ & 13.79 & 10.17 \\
\hline $\mathrm{P}$ & 13.69 & 7.93 \\
\hline $\mathrm{Ca}$ & 11.41 & 5.11 \\
\hline
\end{tabular}






\begin{tabular}{c|c|c}
\hline Element & Wt.\% & At.\% \\
\hline $\mathrm{C}$ & 20.42 & 30.29 \\
\hline $\mathrm{O}$ & 38.47 & 42.84 \\
\hline $\mathrm{Na}$ & 1.41 & 1.09 \\
\hline $\mathrm{Mg}$ & 24.11 & 17.67 \\
\hline $\mathrm{P}$ & 9.07 & 5.22 \\
\hline $\mathrm{Ca}$ & 6.52 & 2.90 \\
\hline
\end{tabular}

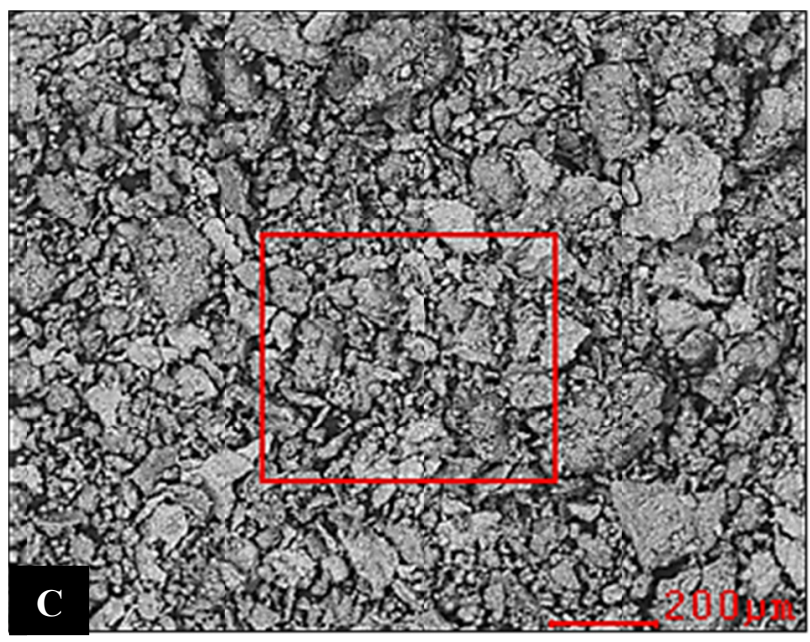

\begin{tabular}{c|c|c}
\hline Element & Wt.\% & At.\% \\
\hline $\mathrm{C}$ & 15.91 & 22.61 \\
\hline $\mathrm{O}$ & 51.04 & 54.44 \\
\hline $\mathrm{Na}$ & 01.09 & 00.81 \\
\hline $\mathrm{Mg}$ & 30.62 & 21.49 \\
\hline $\mathrm{Cl}$ & 01.35 & 00.65 \\
\hline
\end{tabular}

Figure 4-6. Energy dispersive X-ray spectroscopy (EDS) analysis with backscatter detector SEM images of Mg-Zn (A), Mg-Zn-Se (B) surfaces, and precipitate formation of $\mathrm{Mg}-\mathrm{Zn}-\mathrm{Cu}(\mathrm{C})$ after cell growth for 72 hours.

Figure 4-6A, shows the white deposits on the Mg-Zn alloy to consist of elevated levels of 35.49 wt.\% oxygen, 23.92 wt.\% carbon, 13.79 wt.\% magnesium, 13.69 wt.\% phosphorus, and $11.41 \mathrm{wt} \%$ calcium. Comparatively, the Mg-Zn-Se alloy showed the deposits to be composed of 20.42 wt.\% carbon, 38.47 wt.\% oxygen, 24.11 wt.\% magnesium, with 9.07 wt.\% and 6.52 wt.\% of phosphorus and calcium, respectively (Fig. 4-7B). EDS analysis of the precipitate resulting after the 72-hour period of cell growth on the Mg-Zn-Cu alloy revealed 51.04 wt.\% oxygen, 30.62 wt.\% magnesium, and 
15.91 wt.\% carbon. Generally, the deposits on the Mg-Zn, Mg-Zn-Cu, and the Mg-Zn-Se alloys were shown to be composed of ionic salts commonly found in the cell culture medium that reacted with the elements leached from the alloys, as evident from EDS analysis.

\subsection{Discussion}

Understanding the surface properties of an implantable device is vital to determining a fundamental relationship between fluid-cellular and material interactions. In this study, an essential parameter is the surface roughness of the test specimen. The corrosion current and pitting tendency of magnesium alloys has been widely reported to increase with increased surface area as a result of increased surface roughness, and to generally play a vital role in the passivation tendency of the alloys [16-18]. The influences of surface roughness on surface tension measurements are also critical as the deposition of a sessile drop on a rough surface could result in misleading contact angle values as the droplet volume would imbed within the crevices of the test surface [19]. From experimentation, it was observed that the $\mathrm{Mg}-\mathrm{Zn}$ alloy composition was revealed to possess the highest mean surface roughness, resulting in the highest mean contact angle value of $77^{\circ}$ when using ethylene glycol as the liquid probe, and the lowest mean contact angle of $59^{\circ}$ when using DI water as the liquid probe. This difference is attributed to the chemically heterogeneous surface on the magnesium alloys $[14,20]$. As previously reported by Persaud-Sharma et al., the natural air formed oxide layer that develops on the surface of the alloys was shown to be comprised a mixture of elements that include 
carbon, oxygen, nitrogen, magnesium and aluminum as revealed by $\mathrm{X}$-ray photoelectric spectroscopy analysis (XPS) [14].

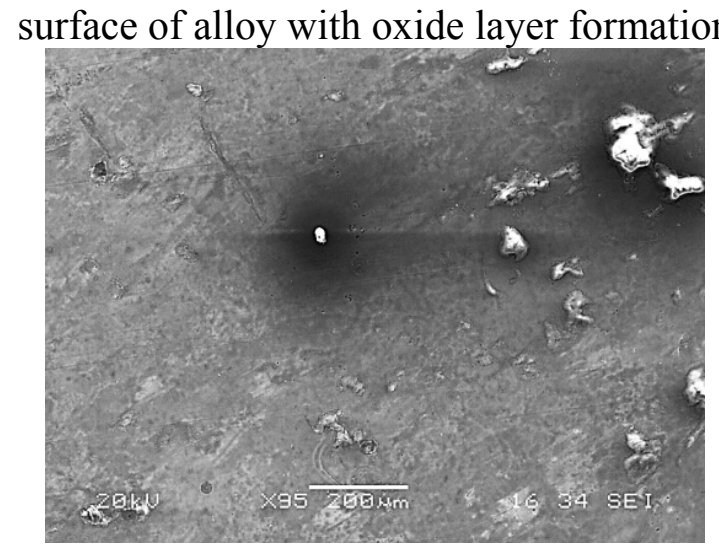

(A) SEM image

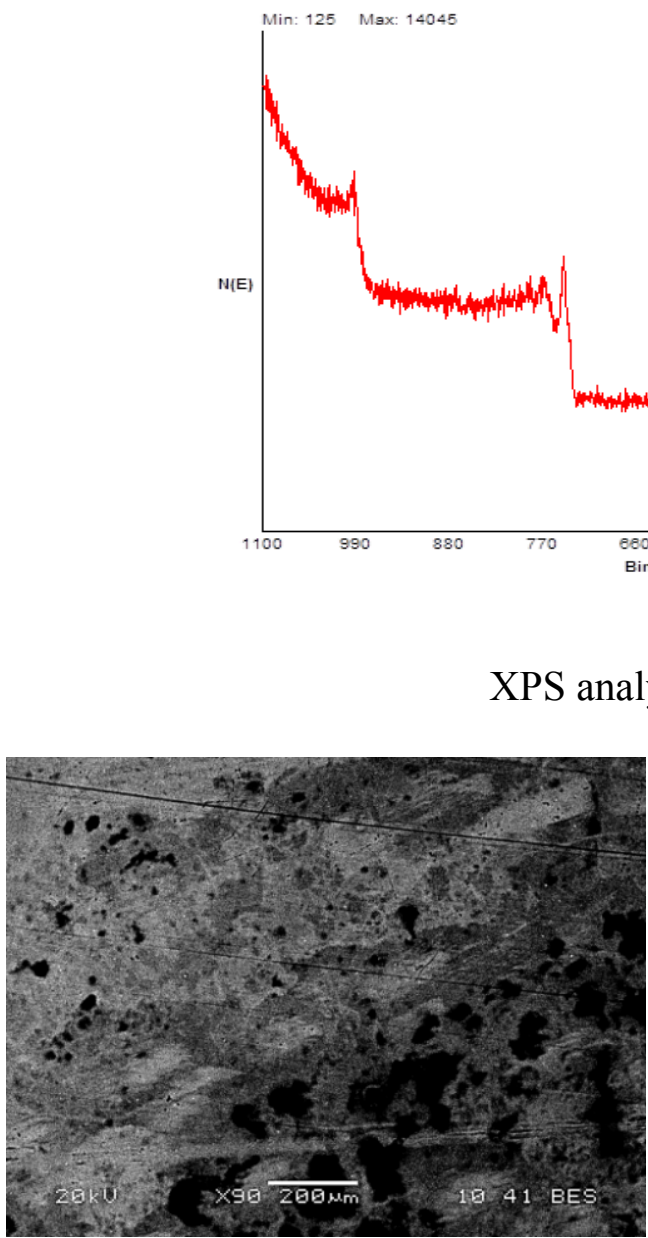

(C) backscatter image

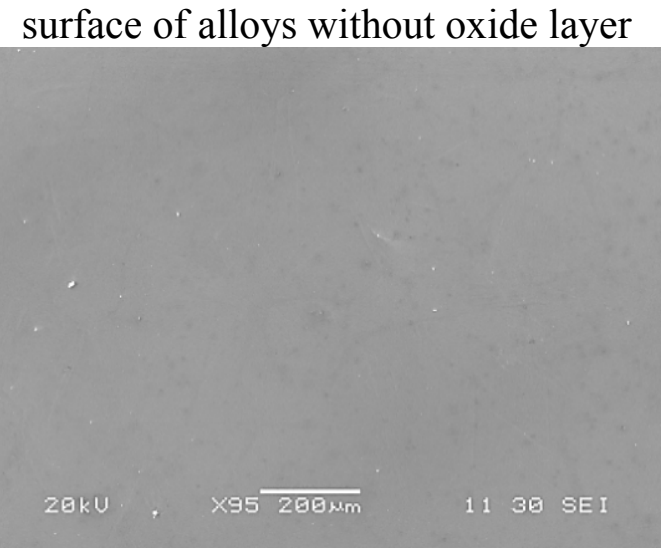

(B) SEM image

Atomic Concentration

Al $2 \mathrm{p} \quad 5.9 \%$

$\begin{array}{ll}\text { O 1s } & 35.5 \% \\ \text { C 1s } & 40.9 \%\end{array}$

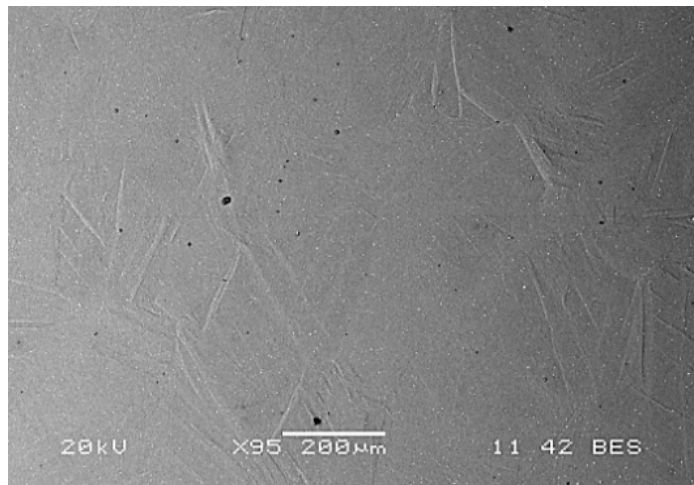

(D) backscatter image 
Figure 4-7. Scanning electron microscopy (SEM) images and X-ray photoelectron spectroscopy (XPS) analysis of oxide layer formation on the Mg-Zn-Se alloy [14].

surface of alloy with oxide layer

formation

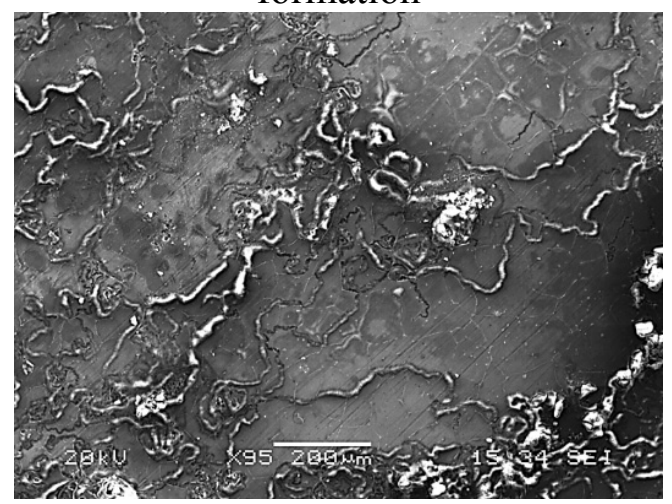

(A) SEM image surface of alloys without oxide layer

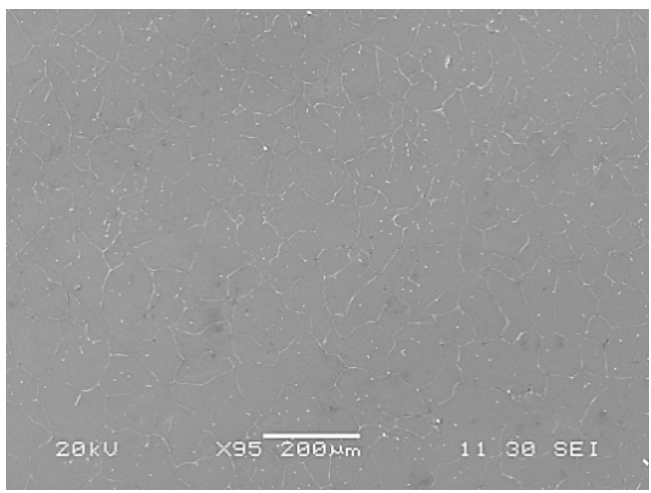

(B) SEM image

XPS analysis of oxide layer



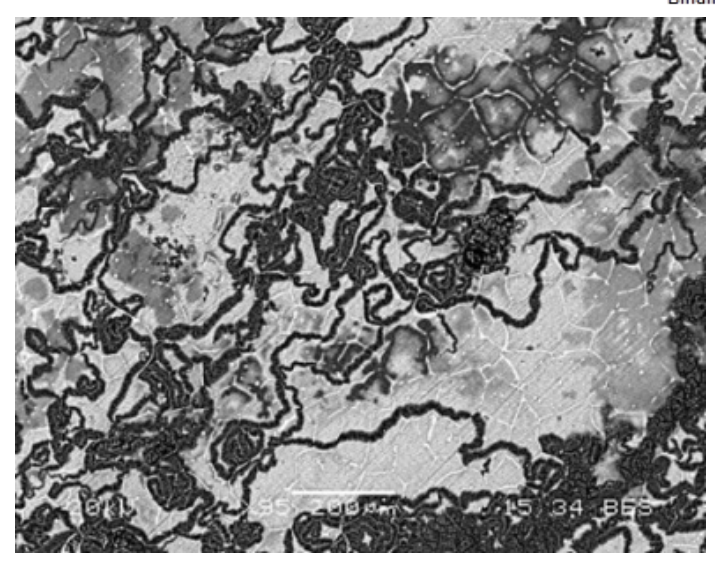

(C) backscatter image

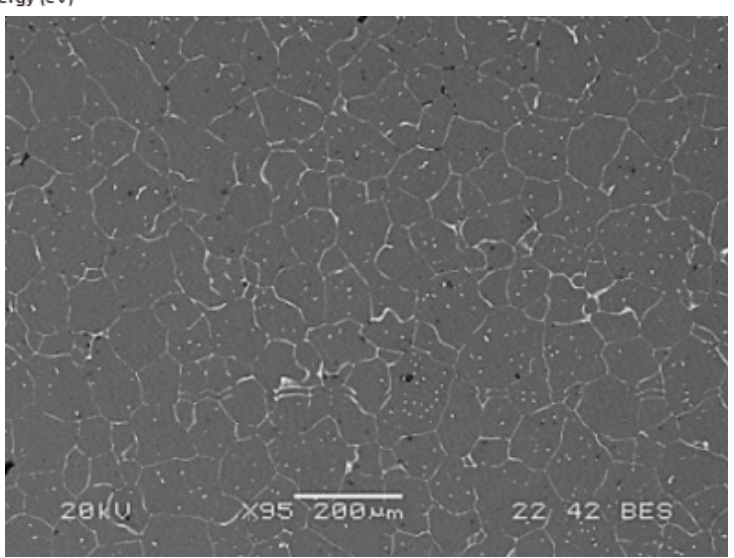

(D) backscatter image 
Figure 4-8. Scanning electron microscopy (SEM) images and X-ray photoelectron spectroscopy (XPS) analysis of oxide layer formation on the $\mathrm{Mg}-\mathrm{Zn}-\mathrm{Cu}$ alloy [14].

The contact angle hysteresis observed amongst the different alloy compositions is partially due to the varying surface roughness of the test specimens, but is also due to the different chemical composition of the air formed oxide layer which directly interacts with the liquid probe droplet used to measure the contact angles (Figures 4-7 \& 4-8). Statistical correlation analysis showed a significant positive correlation $\left(r_{s}=0.830\right)$ between water and ethylene glycol as liquid probes and the contact angle formed. A significant negative correlation was found between surface roughness and the contact angle formed when using ethylene glycol as a liquid probe $\left(r_{s}=-0.283\right)$. This correlation is supported by contact angle and surface roughness parameters widely explored by Young, Wenzel, and Cassie \& Baxter models. Wenzel, Cassie \& Baxter proposed that the liquid probe volumes imbed within the crevices of the rough surfaces or remain distended over trapped air within such crevices, thus resulting in contact angle hysteresis [21-23]. Correction factors developed by Wenzel, Cassie \& Baxter are widely used to correct for such contact angle hysteresis imparted by rough surfaces. However, such corrections were not applied to contact angle data collected, because it was perceived as substantially altering the raw data. Backscatter images for the surfaces of the experimental alloys did not reveal any regions of contrast for distinguishable phases in the $\mathrm{Mg}-\mathrm{Zn}-\mathrm{Se}$ alloy, although notable phase contrast was seen for the $\mathrm{Mg}-\mathrm{Zn}-\mathrm{Cu}$ alloy along the grain boundary structure of the alloy as shown in Figures 4-7 and 4-8, respectively. Thus, despite the same grinding and polishing procedures employed for the three different alloy compositions, the variance in the surface roughness values are attributed to the higher 
mechanical property values for the air formed oxide layers on the alloys as compared to their bare surfaces as previously reported by Persaud-Sharma et al [14].

The cytotoxicological effect of elements leached from the novel biodegradable $\mathrm{Mg}-\mathrm{Zn}-\mathrm{Cu}$ and $\mathrm{Mg}-\mathrm{Zn}-\mathrm{Se}$ alloys was quantified using different in-vitro biological assay tests. These findings were compared to a binary $\mathrm{Mg}-\mathrm{Zn}$ alloy which has shown degradation rates appropriate for wound healing with desirable biocompatibility with host tissues and fluids [24]. Primarily, a Promega-MTS assay was utilized to perform this testing by exposing human foreskin fibroblast cells to the degradation products released from these experimental alloys after alloy samples were immersed and agitated in simulated body fluid for 30 -days at $37^{\circ} \mathrm{C}$ (Fig. 4-1). Fibroblast cells were viable in the $50 \%$ diluted extract solutions obtained from the $\mathrm{Mg}-\mathrm{Zn}-\mathrm{Se}$ and $\mathrm{Mg}-\mathrm{Zn}-\mathrm{Cu}$ alloys, while only cells cultured in the $\mathrm{Mg}-\mathrm{Zn}-\mathrm{Cu}$ alloy extract was shown to have poor cell growth (33\%) when cultured in $100 \%$ concentrated extract media; whereas, the same composition showed to have a $93 \%$ cell growth in the 50/50 dilution. This difference in percentage of cell growth can be explained by the increased copper concentration in the $100 \%$ extract, which can lead to copper toxicity in organisms when copper exceeds a critical threshold for survival [25]. This effect was aggrandized by the lack of nutrients in the $100 \%$ extract medium which was not supplemented with nutrients and antibiotics usually present in cell culture medium through the addition of fetal bovine serum $(10 \%$ FBS) and penicillin, respectively. While the toxicity of copper has been widely published, the necessity of copper as an essential trace mineral serving as an integral role in many enzymes involved in vital biological roles remains irrefutable [15]. Additionally, no alloy composition yielded complete cell cytotoxicity when cultured in 
the $100 \%$ extract media. This is a favorable quality for these experimental degradable magnesium alloys, because it has been reported that degradable polymer's such as polylactide materials have resulted in cellular cytotoxicity because of the dramatic changes in $\mathrm{pH}$ caused by degrading polymers [26]. Although the use of polymeric materials for endovascular applications is a growing field, the concerns of cytotoxicity is not as great of a concern when using biodegradable alloys, as research has shown that cytotoxicity effects are minimal $[27,28]$. However, it should also be noted that the lack of cell growth on the degradable alloys may make it difficult to achieve endothelialization on the surface of the device.

Further testing narrowed the cytotoxic concentration range of $\mathrm{Mg}-\mathrm{Zn}-\mathrm{Cu}$ extract from $65 \%$ to $100 \%$ when cell growth was observed for a 7 day period. Days 1 and 2 of such experimentation showed an increase in cell proliferation compared to the original seeding density with $157 \%$ ([85\% extract $])$ and $117 \%$ ([65\% extract $])$. A precipitous drop in percentage of cell growth was seen on Day 3 where percent cell growth remained low for the duration of the 7 day period (Fig. 4-3). The immediate increase in the percentage of cell growth above $100 \%$ observed on days 1 and 2 is attributed to the effect of copper promoting fibroblast proliferation. This notion is supported by Itoh et al., who previously showed that using copper can stimulate proliferation of mouse embryonic fibroblast cells (MEFs) using a copper chloride $\left(\mathrm{CuCl}_{2}\right)$ solution with a copper mass of 47 percent [29]. Cell proliferation is seen at the $65 \%$ and $85 \%$ extract concentrations on day 1 and day 2 , respectively, because the concentration of the solution has been diluted with pure culture media, thus reducing the concentration of the copper. Initially, the cells have a capacity to buffer and/or utilize the copper absorbed from the culture solution. Although not 
statistically supported, a likely affect is that the $85 \%$ extract concentration solution increased the number of fibroblast cells by $57 \%$ because it contained a higher concentration of copper, as compared to the $65 \%$ extract concentration which only increased the number of fibroblast cells by $17 \%$. However, on day three of the experiment, the cells have most likely become saturated with any useable amount of copper and such saturation became toxic for fibroblast cell survival. The 47 percent copper solution concentration used by Itoh et al., similarly showed MEF proliferation and supports data from the study presented herein that culture media is toxic with extract concentrations of $\mathrm{Mg}-\mathrm{Zn}-\mathrm{Cu}$ ranging from 65 to 100 percent. Thus, the precipitous cell death observed on day 3 can be explained by the cell saturation of copper, which is ultimately the effect of copper toxicity. Therefore, the critical limit for human foreskin fibroblast cell survival to copper exposure from the $\mathrm{Mg}-\mathrm{Zn}-\mathrm{Cu}$ alloy is as high as an extract concentration of $<65 \%$.

Although not reaching statistical significance, LDH quantification showed that fibroblast cells cultured in direct exposure to the Mg-Zn-Se alloy had a lower percent cytotoxicity than those directly in contact with the Mg-Zn alloy, as both alloys showed a maximum cytotoxicity of approximately $35 \%$. This means that more than $64 \%$ of the cells in direct exposure to these experimental alloys survived (Fig. 4-5). However, data from the direct contact assay evaluating cell adhesion on the surface of these alloys show that cells cannot adhere or grow on the surface of the materials (Fig. 4-6). According to studies performed by Huan et al., and Keim et al., the lack of cell growth on the substrate is common for many types of magnesium alloys and is attributed to the large amounts of hydrogen evolution from magnesium alloys which dramatically increases the $\mathrm{pH}$ levels 
within the immediate vicinity of the magnesium implants which prevents cellular adhesion $[7,30]$. This is supported with physical observations of cell culture media with the $\mathrm{Mg}-\mathrm{Zn}-\mathrm{Cu}$ alloy specimens changing color from being red to faintly yellow/mostly clear. This color transition is only possible if the $\mathrm{pH}$ of the solution changed from neutral/basic conditions to more acidic conditions with a $\mathrm{pH}$ less than 6.8. This observation can be explained by the increased evolution of hydrogen gas from the Mg$\mathrm{Zn}-\mathrm{Cu}$ alloys which increase the presence of hydrogen ions within the cell culture media. Additionally, experimentation with the $\mathrm{Mg}-\mathrm{Zn}-\mathrm{Cu}$ alloy showed that the entire material corroded within the experimental time period, thus no cell adhesion or LDH amounts could be quantified. The lack of cellular adhesion seen on the alloys is further supported by the low Zisman surface energy values for each alloy, which is consistent with Baier et al. and van der Valk et al., who determined that materials with low surface energies show low cell attachment $[31,32]$. It is important to note that all tests were conducted in-vitro, which is not a true presentation of an actual implant. Naturally, when a device or material is implanted in-vivo, the fluid conditions will not be static and fresh nutrient-rich biological fluids will create an environment capable of sustaining cell growth and viability.

A particularly interesting finding was the complete degradation of the $\mathrm{Mg}-\mathrm{Zn}-\mathrm{Cu}$ alloy and the deposition of salts on the surface of the Mg-Zn and Mg-Zn-Se alloys as evidenced by SEM/EDS analysis (Fig. 4-6F, 4-6D, and 4-6E, respectively). As shown in Figure 4-6, the analysis of these products showed them to consist primarily of oxygen, magnesium, sodium, phosphorus, and calcium, which are all salts found in the simulated body fluid (DMEM) that reacted with the magnesium alloys and their leachate to form 
precipitates that deposited on the alloy surface. This is consistent with the findings of Keim et al., who also reported increased deposits of the same elements (Fig. 4-6) [30]. The most likely chemical products formed from the interaction of these materials are $\mathrm{Mg}(\mathrm{OH})_{2}$ and $\mathrm{MgCl}_{2}$ according to equations (2), (3) and (4) [6,33]. Generally, once the magnesium materials are immersed within an electrolytic media, the alloys are attacked by the chloride salts or anion species within the media. In this case, the chloride, sulfate, phosphate, carbonate, sodium, and oxygenated species are attacking the surface of magnesium. The chlorides and fluorides are the most damaging species because of their high electronegativity values and affinity for metallic species. This would explain the increased detection of chlorine in the EDS analysis of the degradation product for the $\mathrm{Mg}-\mathrm{Zn}-\mathrm{Cu}$ alloy which underwent complete degradation. Xin et al., has proposed that the chloride ions can react with the $\mathrm{Mg}(\mathrm{OH})_{2}$ layer that forms on the surface of magnesium alloys and transform it to a more soluble $\mathrm{MgCl}_{2}$ intermediate as shown in Eq.(3) [33].

$$
\begin{array}{cc}
\mathrm{Mg}^{+2}+2 \mathrm{H}_{2} \mathrm{O} \longrightarrow \mathrm{Mg}(\mathrm{OH})_{2}+\mathrm{H}_{2} & \text { Eq. (2) } \\
\mathrm{Mg}^{+2}+\mathrm{Cl}^{-} \longrightarrow \mathrm{MgCl}_{2} & \text { Eq. (3) } \\
\mathrm{Mg}(\mathrm{OH})_{2}+4 \mathrm{Cl}^{-} \longrightarrow \mathrm{MgCl}_{2}+\mathrm{Cl}_{2}+2 \mathrm{OH}^{-} & \text {Eq. (4) } \\
3 \mathrm{Mg}\left(\mathrm{H}_{2} \mathrm{PO}_{4}\right)_{2}+4 \mathrm{H}_{2} \mathrm{O} \longrightarrow \mathrm{Mg}_{3}(\mathrm{PO} 4)_{2} \cdot 4 \mathrm{H}_{2} \mathrm{O}+4 \mathrm{H}_{3} \mathrm{PO}_{4} & \text { Eq. (5) }
\end{array}
$$

The presence of phosphorus, calcium, and magnesium deposited on the surface of the experimental alloys can be explained by the precipitation of insoluble tertiary magnesium phosphate. As the magnesium alloy undergoes corrosion, a substantial 
amount of $\mathrm{Mg}^{+2}$ ions are released into the solution. The increased concentration of $\mathrm{Mg}^{+2}$ ions prevents the precipitation of calcium phosphate which is found in the SBF, and rather forms magnesium phosphate $\left(\mathrm{Mg}_{3}\left(\mathrm{PO}_{4}\right)_{2}\right)$ according to Eq. (5) [34]. The insoluble magnesium phosphate would then deposit on the surface of the implant. The formation of these insoluble products can potentially reduce the release of the $\mathrm{Mg}^{+2}$ ions resulting from the oxidation of the magnesium implant, as suggested by Keim et al. [30]. Keim suggests that the most efficient method of reducing $\mathrm{Mg}^{+2}$ ions from being released by the implant is the nearly spontaneous formation of a biomimetic coating composed of calcium, carbon, and phosphorus which are all elements identified in the degradation precipitate of $\mathrm{Mg}-\mathrm{Zn}-\mathrm{Cu}$ and the deposited layer on the $\mathrm{Mg}-\mathrm{Zn}$ and $\mathrm{Mg}-\mathrm{Zn}-\mathrm{Se}$ alloys formed from their degradation products (Fig. 4-6). This nearly instantaneous protective layer has been shown to reduce the oxidation of the magnesium implant by as much as $60 \%$ as compared to polished and surface treated magnesium alloys [30].

\subsection{Conclusions}

In this study, in-vitro experimentation to assess the biocompatibility of novel ternary magnesium alloys $\mathrm{Mg}-\mathrm{Zn}-\mathrm{Se}$ and $\mathrm{Mg}-\mathrm{Zn}-\mathrm{Cu}$ was performed. This study presents the first evaluation of these biodegradable alloys, which have the potential to serve as effective endovascular medical devices. The percentage of cell growth in exposure to these alloys was examined by an MTS assay using human foreskin fibroblast cells. It was found that cells cultured in a diluted 50/50 (30-day extract solution/fresh DMEM) was shown to have cell growth above $90 \%$ for all alloy compositions (Mg-Zn-Cu, Mg-Zn, and $\mathrm{Mg}-\mathrm{Zn}, \mathrm{Se}$ ). Cells cultured in the $100 \%$ and the 50/50 extract solution of the Mg-Zn-Se 
alloy showed to have a higher percentage of cell growth than the binary Mg-Zn alloy without the element Se. Cell growth was 33\% when cultured in a $100 \%$ extract solution obtained from the $\mathrm{Mg}-\mathrm{Zn}-\mathrm{Cu}$ alloy. It was further identified that extract concentrations from $65-100 \%$ of the $\mathrm{Mg}-\mathrm{Zn}-\mathrm{Cu}$ alloy is the most harmful for fibroblasts and lead to cell death. Cytotoxicity of cells in direct contact with the magnesium alloys was quantified using a membrane integrity assay and showed that fibroblast cells in direct contact with the $\mathrm{Mg}-\mathrm{Zn}-\mathrm{Se}$ alloy resulted in lower cytotoxicity than those in directed contact with the Mg-Zn alloy with cytotoxicity levels reaching 34 and 36 percent, respectively. Cells did not grow on the surface of any magnesium alloys, although cells surrounding the alloy test specimens remained viable. A significant positive correlation was revealed between the liquid probe used and the contact angle formed; while a negative correlation was determined between surface roughness and contact angle formed using ethylene glycol as the liquid probe.

\subsection{References}

1. Moravej, M., Mantovani, M. Biodegradable metals for cardiovascular stent application: interest and new opportunities. International Journal of Molecular Science. 2011; 12: 4250 - 4270.

2. Ma, E., X, J. Biodegradable Alloys: The glass window of opportunities. Nature Materials. 2009; 8: 855-857.

3. Hermawan, H., Dubé, D., Mantovani, D. Degradable metallic biomaterials: design and development of Fe-Mn alloys for stents. Journal of Biomedical Material Research: A. 2010; 93: 1-11.

4. Liu, B., Zheng, Y.F., Ruan, L. In-vitro investigation of Fe30MnSi shape memory alloy as a potential biodegradable material. Materials Letters. 2011; 65: 540-543. 
5. Lendlein, A., Neffe, A., Pierce, B., Vienken, J. Why are so few degradable polymeric biomaterials currently established in clinical applications? International Journal of Artificial Organs. 2011; 34: 71-75.

6. Persaud-Sharma, D., McGoron A. Biodegradable magnesium alloys: a review of material development and applications. Journal of Biomimetics, Biomaterials and Tissue Engineering. 2012; 12: 25-39.

7. Huan, Z.G., Leeflang, M.A., Zhou, J., Fratila-Apachitei, L.E., Duszczyk, J. In-vitro degradation behavior and cytocompatibility of $\mathrm{Mg}-\mathrm{Zn}-\mathrm{Zr}$ alloys. Journal of Material Science: Materials in Medicine. 2010; 21: 2623-2635.

8. Babkin, V.M. Effect of zirconium on the grain size of magnesium containing $4.5 \%$ Zn. Metal Science and Heat Treatment. 2004; 5: 543-544.

9. Benson, J.M. Safety considerations when handling metal powders. The Journal of the South African Institute of Mining and Metallurgy. 2012; 7: 563-575.

10. Rederstoff, M., Krol, A., Lescure, A. Understanding the importance of selenium and selenoproteins in muscle function. Cellular and Molecular Life Science. 2006; 63: 52-59.

11. Hartfield, D.L. Introduction to Selenium, Selenium: Its Molecular Biology and Role in Human Health. 2001. Kluwer, Boston.

12. Turnlund, J.R.Copper: Shils, M.E., Shike, M., Ross, A.C., Caballero, B., Cousins, R.J. Modern Nutrition in Health and Disease. $10^{\text {th }}$ edition. Philadelphia: Lippincott, Williams \& Wilkins. 2006: 286-299.

13. Angelova, M., Asenova, S., Nedkova, V., Koleva-Kolarova, R. Copper in the Human Organism. Trakia Journal of Sciences. 2011; 9: 88-98.

14. Persaud-Sharma, D., Budiansky, N., McGoron, A. Mechanical properties and tensile failure analysis of novel-bioabsorbable $\mathrm{Mg}-\mathrm{Zn}-\mathrm{Cu}$ and $\mathrm{Mg}-\mathrm{Zn}-\mathrm{Se}$ Alloys for endovascular applications. Metals. 2013; 3: 23-40.

15. Gaetke, L.M., Chow, C.K. Copper toxicity, oxidative stress, and antioxidant nutrients. Toxicology. 2003; 189: 147-163.

16. Alvarez, R., Martin, H., Horstemeyer, M.F., Chandler, M., Williams, N., Wang, P., Ruiz, A. Corrosion relationship as a function of time and surface roughness on a structural AE44 Magnesium alloy. Corrosion Science. 2010; 52: 1635-1648.

17. Walter, R., Kannan, B. Influence of surface roughness on the corrosion behavior of magnesium alloy. Materials and Design. 2011; 32: 2350-2354. 
18. Persaud-Sharma, D., Munroe, N., McGoron, A.J. Electro and magnetoelectropolished surface micro-patterning on binary and ternary Nitinol. Trends in Biomaterials and Artificial Organs. 2012; 26: 74-85.

19. Hiemenz, P.C., Rajagopolan, R. Principles of Colloid and Surface Chemistry. 1997, $3^{\text {rd }}$ Edition, Marcel Dekker, Inc.

20. Grundke, K. "Wetting, Spreading, and Penetration." Handbook of Applied Surface and Colloid Chemistry. 2002, Holmberg, K. Editor, John Wiley \& Sons, Ltd.

21. Young, T. Philosophical transaction of the royal society of London. 1805; 95: 65-87.

22. Wenzel, R.N. Industrial and engineering chemistry. 1936; 28: 988-944.

23. Cassie, A.B.D., Baxter, S. Transactions of the faraday society. 1944; 40: 546.

24. Chen, D., He, Y., Tao, H., Zhang, Y., Jiang, Y., Zhang, X., Zhang, S. Biocompatibility of magnesium-zinc alloy in biodegradable orthopedic implants. International Journal of Molecular Medicine. 2011; 28: 343-348.

25. Brewer, GJ. The risks of copper-toxicity contributing to cognitive decline in the aging population and to Alzheimer's disease. Journal of the American College of Nutrition. 2009; 28: 238-242.

26. Marques, A.P., Reis, R.L., Hunt, J.A. The biocompatibility of novel starch-based polymers and composites: in-vitro studies. Biomaterials. 2003; 23: 1471-1478.

27. Berglund, I., Brar, H., Dolgova, N., Acharya, A., Keselowsky, B., Sarntinoranont, M., Manuel, M. Synthesis and Characterization of Mg-Ca-Sr alloys for biodegradable orthopedic implant applications. Journal of Biomedical Materials Research: Part B. 2012; 100B: 1524-1534.

28. Bornapour, M., Muja, N., Shum-Tim, D., Cerruti, M., Pekguleryuz, M. Biocompatibility and biodegradability of $\mathrm{Mg}-\mathrm{Sr}$ alloys: The formation of Srsubstituted hydroxyapatite. Acta Biomaterialia. 2013; 9: 5319-5330.

29. Itoh, S, Kim, H., Nakagawa, O., Ozumi, K., Lessner, S., Aoki, H., Akram, K., McKinney, R., Ushio-Fukai, M., Fukai, T. Novel role of antioxidant-1 (Atox1) as a copper-dependent transcription factor involved in cell proliferation. Journal of Biological Chemistry. 2008; 283: 9157-9167.

30. Keim, S., Brunner, J., Fabry, B., Virtanen, S. Control of magnesium corrosion and biocompatibility with biomimetic coatings. Journal of Biomedical Materials Research B: Applied Biomaterials. 2011; 96B: 84-90. 
31. Baier, RE., Meyer, AE., Natiella, JR., Natiella, RR., Carter, JM. Surface properties determine bioadhesive outcomes: methods and results. Journal of Material Research. 1984; 18: 337-355.

32. van der Valk, P., van Pelt AWJ., Busscher, HJ., De Jong, HP., Wildeyuur, CRH., Arends, J. Interaction of fibroblasts and polymer surfaces: relationship between surface free energy and fibroblasts spreading. Journal of Biomedical Material Research. 1983; 17: 807-817.

33. Xin,Y., Liu, C., Zhang, X., Tang, G., Tian, X., Chu, P. Corrosion behavior of biomedical AZ91 magnesium alloy in simulated body fluids. Journal of Materials Research. 2007; 22: 2004-2011.

34. Morks, M.F. Magnesium phosphate treatment of steel. Material Letters. 2004; 58: 3316-3319. 


\section{CHAPTER 5 \\ IN-VITRO DEGRADATION BEHAVIOR of TERNARY Mg-Zn-Se and Mg-Zn-Cu ALLOYS AS BIOMATERIALS}

\section{$5.1 \quad$ Introduction}

This study explores the corrosion behavior of novel as-cast $\mathrm{Mg}-\mathrm{Zn}-\mathrm{Se}$ and $\mathrm{Mg}$ $\mathrm{Zn}-\mathrm{Cu}$ alloys first presented by Persaud-Sharma et al [1]. Magnesium alloys have been widely explored as suitable materials for biomedical implantation due to their ability to degrade in-situ, demonstrate a non-toxic behavior with living tissues, and possess the physical and mechanical properties that are suitable for a multitude of applications [2-6]. However, one of the main limitations of using magnesium alloys in many applications is its unfavorable degradation rate with physical and mechanical properties that change during the degradation process resulting in unsuitable qualities needed for specific biomedical applications [6]. The high susceptibility to corrosion can be mitigated using techniques such as surface coatings, anodizing and alloying techniques which have been explored in an effort to increase the applicability of magnesium and its alloys [7]. In attempts to address the problem of corrosion and other unsuitable mechanical properties of magnesium alloys that have been previously explored, such as the as-cast AZ31 and AZ91D alloys, novel as-cast magnesium alloys $\mathrm{Mg}-\mathrm{Zn}-\mathrm{Se}$ and $\mathrm{Mg}-\mathrm{Zn}-\mathrm{Cu}$ alloys were developed and have been shown to possess enhanced mechanical properties when compared with other as-cast magnesium alloys [1].

In order to determine the corrosion rate of the magnesium alloys, it is best practice to evaluate materials using both gravimetric weight loss and electrochemical techniques. These techniques complement each other, thus permitting for a more complete understanding of the corrosion behavior of a material. One of the main purposes 
of in-vitro testing is to simulate in-situ conditions. For materials used for biomedical applications, corrosion testing procedures are usually performed at temperatures of $37^{\circ} \mathrm{C}$ which is representative of biological subjects, and performed using static fluid conditions which are not representative, but more easily controlled in laboratory conditions. This fails to account for the influence of fluid kinetic contributions to the corrosion rate of the material which has been shown to alter the corrosion mechanism and corrosion rate of the material as high as six times that determined under static conditions [8]. This shortfall may grossly underestimate or overestimate the corrosion performance of the biomaterial once implanted within a patient.

Additionally, testing protocols to simulate vascular conditions fail to use an aqueous media which is truly representative of human blood and/or plasma. Through widely reported studies, it is known that the inclusion of proteins within the testing solution greatly influences the corrosion rate regardless of the electrolytic medium utilized [9-12]. However, the inorganic components included in such media do not accurately represent those found in human plasma. One such media that accurately mirrors the ionic concentrations and $\mathrm{pH}$ of human plasma is Kokubo's solution developed by Kokubo et al [13]. A comparison of chemical formulation of Kokubo's solution, Dulbecco's solution, and Human Plasma is shown in Table 1. Performing corrosion tests using Kokubo's solution provides a more accurate simulation of the environment that would be expected once implanted in-vivo than if using a phosphate buffered saline, as it considers the influence of the various organic and inorganic ions on the corrosion rate of a metal, and therefore a more accurate corrosion rate should be expected. 
Table 5-1. Comparison of ion concentration for Kokubo's solution, DMEM, and human blood plasma

\begin{tabular}{|c|c|c|c|}
\hline \multirow{2}{*}{ Ion } & \multicolumn{3}{|c|}{ Concentration (mmol/dm $\mathbf{~}^{\mathbf{3}}$ ) } \\
\cline { 2 - 4 } & $\begin{array}{c}\text { Kokubo's Simulated } \\
\text { Body Fluid }\end{array}$ & $\begin{array}{c}\text { Human Blood } \\
\text { Plasma }\end{array}$ & $\begin{array}{c}\text { Dulbecco's Modified Eagle's } \\
\text { Medium (D.M.E.M.) }\end{array}$ \\
\hline $\mathrm{Na}^{+}$ & 142.0 & 142.0 & 55.28 \\
\hline $\mathrm{K}^{+}$ & 5.0 & 5.0 & 2.81 \\
\hline $\mathrm{Mg}^{+2}$ & 1.5 & 1.5 & 0.16 \\
\hline $\mathrm{Ca}^{+2}$ & 2.5 & 2.5 & 0.65 \\
\hline $\mathrm{Cl}^{-}$ & 147.8 & 103.0 & 68.19 \\
\hline $\mathrm{HCO}_{3}^{-}$ & 4.2 & 27.0 & 0.63 \\
\hline $\mathrm{HPO}_{4}^{-2}$ & 1.0 & 1.0 & 0.65 \\
\hline $\mathrm{SO}_{4}^{-2}$ & 0.5 & 0.5 & \\
\hline
\end{tabular}

See reference $[13,14]$.

The experimental study evaluates the corrosion behavior of as-cast magnesium alloys $\mathrm{Mg}-\mathrm{Zn}-\mathrm{Se}$ and $\mathrm{Mg}-\mathrm{Zn}-\mathrm{Cu}$, characterized using both gravimetric weight loss methods over a 30-day period under dynamic conditions and electrochemical potentiodynamic tests using Kokubo's solution as an in-vivo simulation solution. These results were compared with a binary $\mathrm{Mg}-\mathrm{Zn}$ alloy used as a control composition. The aim was to characterize the corrosion behavior of the experimental $\mathrm{Mg}-\mathrm{Zn}-\mathrm{Se}$ and $\mathrm{Mg}-\mathrm{Zn}-\mathrm{Cu}$ alloys. 


\subsection{Materials and Methods}

\subsubsection{Alloy manufacturing and sample preparation}

The alloy compositions were synthesized using an Arc-melting method in inert argon gas at ACI alloys, Inc. (CA, USA). Both alloy compositions were composed of wt.\% ratios (98/1/1) $\mathrm{Mg}-\mathrm{Zn}-\mathrm{Cu} / \mathrm{Se}$.

Table 5-2. Weight percentage of alloy compositions (Wt. \%)

\begin{tabular}{|c|c|c|c|c|}
\hline Alloy Composition & $\mathrm{Mg}$ & $\mathrm{Zn}$ & $\mathrm{Cu}$ & $\mathrm{Se}$ \\
\hline $\mathrm{Mg}-\mathrm{Zn}(98 / 01)$ & 99 & 1 & - & - \\
\hline $\mathrm{Mg}-\mathrm{Zn}-\mathrm{Se}(98 / 01 / 01)$ & 98 & 1 & - & 1 \\
\hline $\mathrm{Mg}-\mathrm{Zn}-\mathrm{Cu}(98 / 01 / 01)$ & 98 & 1 & 1 & - \\
\hline
\end{tabular}

Materials were cast in a $25.4 \mathrm{~mm}$ x $25.4 \mathrm{~mm}$ x $152.4 \mathrm{~mm}$ mold. Test specimens were cut into testing dimensions of approximately $10 \mathrm{~mm} \times 10 \mathrm{~mm}$ x $.95 \mathrm{~mm}$. Samples were mechanically dry ground to a \#1200 grit finish using silicon carbide abrasive paper. After mechanical polishing, test specimens were cleaned in acetone and rinsed with deionized water and blown dry with nitrogen gas. Test specimens were stored in a plastic bag until further testing.

\subsubsection{Electrochemical testing procedures}

To assess the corrosion properties and the susceptibility of the magnesium alloys to localized corrosion, electrochemical testing procedures were conducted using ASTM standard F2129-08 and ASTM G5 as a general guide. To prepare the actual testing specimen, an appropriate length of electrical wire was affixed to the alloy sample. A nickel ribbon was spot welded to the magnesium alloy sample. A small amount of 
conductive silver epoxy or silver was used to join the sample to the electrical conductive support wire. The electrical conductivity between the sample and the electrical wire was checked using a handheld multi-meter to ensure that the connection was conductive. An appropriate sealant such as DOW RTV 3140 silicone rubber was used to ensure insulation of the electrical connection and prevent any unwanted region of the sample being exposed to the testing electrolytic media. The exposed surface area of the prepared specimen recorded from optical microscope images of the samples using ImageJ software.

A Gamry potentiostat and Gamry DC 105 software was used for cyclic potentiodynamic corrosion testing. All potentials were measured with respect to a saturated calomel electrode (SCE). Reference electrodes were checked on a regular basis to ensure the measured potential was less than $2 \mathrm{mV}$ difference compared to a master reference electrode. Kokubo's solution was made using procedures outlined by Kokubo et al. $[13,14]$, and used as the electrolytic testing solution with ion concentrations shown in Table 5-1. A Princeton Applied Research K0047 corrosion cell was used for testing. A graphite rod counter-electrode and a saturated calomel reference electrode were used. Approximately 1 liter of test solution was added to the test cell. The test cell was heated to $37^{\circ} \mathrm{C}$ in a heated water bath. Deaeration was performed using ultra high purity nitrogen at a flow rate of $150 \mathrm{cc} / \mathrm{min}$. The system was deaerated for at least 30 minutes prior to testing. The open circuit potential or rest potential was monitored for approximately 1 hour prior to cyclic polarization testing. Cyclic polarization testing was measured from $0.250 \mathrm{mV}$ to 1 volt on the saturated calomel electrode scale (VSCE), with a scan rate of 1 
$\mathrm{mV} / \mathrm{sec}$. The potential scan was reversed upon reaching the vertex potential or preset current density. Two cyclic polarization tests were conducted for each alloy material.

\subsubsection{Tafel extrapolation from voltammetry curves}

After cyclic potentiodynamic testing was completed, Tafel plots (current density vs. $\log$ current (i)) were generated in accordance with ASTM G-102. Tangential extrapolation lines to determine the $\mathrm{E}_{\mathrm{cor}}$ and $\mathrm{I}_{\mathrm{cor}}$ potentials on the Tafel plot curves were analyzed with tangential lines drawn at $+/-50 \mathrm{mV}$ from the open circuit potential. The corrosion rate (C.R.) in mm/year for each alloy was determined in accordance with Faraday's law as shown in equation 1 . Accordingly, $\mathrm{K}_{1}=3.27 \times 10^{-3} \mathrm{~mm} \cdot \mathrm{g} / \mu \mathrm{A}$, icor in $\mu \mathrm{A} / \mathrm{cm}^{2}, \rho$ is the density of the alloy and is measured in $\mathrm{g} / \mathrm{cm}^{3}$, and equivalent weight (EW) is considered dimensionless. The equivalent weight for each alloy was calculated according to equation 2. Accordingly, 'ni' is the valence state of the alloying element, 'fi' is the mass fraction of the alloying elements, and 'Ai' is the atomic weight of the alloying element.

$$
\begin{aligned}
& \text { C.R. }=\mathrm{K}_{1} \cdot \frac{i c o r}{\rho} \cdot \mathrm{EW} \\
& \text { EW Alloy }=\left(\sum \frac{n i f i}{A i}\right)^{-1}
\end{aligned}
$$

\subsubsection{Gravimetric weight loss tests}

Experimentation to measure the weight loss of the alloys once immersed in a simulated body fluid was performed. For these tests, Dulbecco's modified eagles medium (composition type Sh30081.01) was used as the simulated body fluid (SBF). A container 
was filled with $300 \mathrm{~mL}$ of the selected $\mathrm{SBF}$, heated and maintained at $37^{\circ} \mathrm{C}$ for 30 days, and continuously agitated at $300 \mathrm{rpm}$ for 30 days using a MaxQ 4000 Barnstead Labline orbital shaker. This was performed to simulate a shear force $\left(\tau_{\max }\right)$ of $14.5 \mathrm{dynes} / \mathrm{cm}^{2}$ exerted on the testing specimens as shown in equation 3. Accordingly, 'a' is the orbital radius of the shaker, ' $\eta$ ' is the viscosity of the culture medium $(0.0075$ poise $)$, ' $\rho$ ' is the density of the culture medium $(1.09 \mathrm{~g} / \mathrm{mL})$, and ' $\mathrm{f}$ ' is the frequency of rotation.

$$
\tau_{\max }=\mathrm{a} \sqrt{\left(\eta \rho(2 \pi f)^{3}\right)}
$$

The weight of the sample was measured to $1 / 1000^{\text {th }}$ of a milligram before being immersed in the SBF, and after the 30 day experimentation. Prior to weighing specimens after being removed from the SBF, samples of $\mathrm{Mg}-\mathrm{Zn}$ and $\mathrm{Mg}-\mathrm{Zn}-\mathrm{Se}$ were blown dry with nitrogen gas. Weighing measurements were recorded using a Fisher Scientific Accu124 scale. Twenty-four hours after immersing the alloy specimens into the SBF, and every 24 hrs thereafter, aliquots of the SBF were removed for inductively coupled plasma mass spectrometry (ICP-MS) analysis to characterize ion evolution from the alloys. $\mathrm{pH}$ measurements were recorded on such aliquots throughout the 30 day experimental period using an Accumet Research AR50 pH meter.

\subsubsection{Inductively Coupled Plasma Mass Spectrometry Analysis}

ICP-MS analysis was performed on the aliquots removed from the $300 \mathrm{~mL}$ volume which was exposed to continuous shaking and heating at $37^{\circ} \mathrm{C}$. Prior to performing ICP-MS analysis, the SBF samples underwent acid digestion using nitric acid and hydrogen peroxide at $90^{\circ} \mathrm{C}$ to remove all organic components from the SBF that 
cannot be quantified or tolerated by mass spectrometry equipment. Additionally, before ICP-MS analysis, the aliquot samples were diluted with $9975 \mu \mathrm{L}$ of nitric acid $(0.8 \mathrm{M}$ Optima Grade), vortexed and sonicated for 15 minutes. Rhodium was used as the internal standard with concentrations of 50 parts per billion (ppb). These samples were measured for the detection of trace elements commonly found within magnesium alloys such as iron and aluminum. Subsequently, a further dilution was then applied to the volumetric samples to attain a final dilution factor of 1:1000 to detect elements at higher concentrations such as magnesium, zinc, copper, and selenium. This batch used Yttrium as the internal standard. Each sample was analyzed in 3 replicates. Deionized water (18 Mohms) and optima grade nitric acid was used to prepare the calibration curve with 0 , $10,25,50,60,80$, and $100 \mathrm{ppb}$ of the standards. Calibration was ensured by obtaining good linearity for calibration elements and isotopes $\left(\mathrm{r}^{2}=0.99\right)$.

\subsection{Results}

Table 5-3 shows the corrosion rates as determined by gravimetric and electrochemical methods for the experimental magnesium alloys $\mathrm{Mg}-\mathrm{Zn}-\mathrm{Cu}, \mathrm{Mg}-\mathrm{Zn}-\mathrm{Se}$, and the binary Mg-Zn alloy used as a comparative control. 
Table 5-3. Corrosion Rates for Magnesium Alloys Determined by Electrochemical and Gravimetric Methods, Stent Strut Thickness and Degradation Time Estimates Data represented as mean \pm standard deviation; ${ }^{*}$ Statistical Difference $(p<0.05) \mathrm{N}=5$

(Sample size).

\begin{tabular}{|c|c|c|c|c|}
\hline $\begin{array}{c}\text { Alloy } \\
\text { Composition }\end{array}$ & $\begin{array}{l}\text { Corrosion Rate } \\
\qquad \text { (C.R.) } \\
\text { Determined by } \\
\text { Electrochemical } \\
\text { Testing }\end{array}$ & $\begin{array}{c}\text { Corrosion } \\
\text { Rate (C.R.) } \\
\text { Determined } \\
\text { by } \\
\text { Gravimetric } \\
\text { Testing }\end{array}$ & $\begin{array}{c}\text { Stent Strut } \\
\text { Thickness } \\
\text { Necessary for a } 6 \\
\text { Month Degradation } \\
\text { Period }\end{array}$ & $\begin{array}{c}\text { Length of Time } \\
\text { (Days) for Complete } \\
\text { Degradation with a } \\
0.016 \mathrm{~cm} \text { Strut } \\
\text { Thickness }\end{array}$ \\
\hline & $\mathrm{mm} \cdot \mathrm{yr}^{-1}$ & $\mathrm{~mm} \cdot \mathrm{yr}^{-1}$ & $\begin{array}{c}\text { Electrochemical } \\
\text { (C.R.)/Gravime } \\
\text { tric (C.R.) }\end{array}$ & $\begin{array}{c}\text { Electrochemical } \\
\text { (C.R.)/Gravime } \\
\text { tric (C.R.) }\end{array}$ \\
\hline $\mathrm{Mg}-\mathrm{Zn}$ & $19.5 \pm 5.26^{*}$ & $2.16 \pm 0.855^{*}$ & $2.34 \mathrm{~cm} / 0.259 \mathrm{~cm}$ & 3 Days / 27 days \\
\hline $\mathrm{Mg}-\mathrm{Zn}-\mathrm{Se}$ & $44.8 \pm 8.87^{*}$ & $0.428 \pm 0.19^{*}$ & $5.28 \mathrm{~cm} / 0.051 \mathrm{~cm}$ & $\begin{array}{c}1 \text { Day } 8 \text { Hours / } 136 \\
\text { Days }\end{array}$ \\
\hline $\mathrm{Mg}-\mathrm{Zn}-\mathrm{Cu}$ & $44.4 \pm 14.9^{*}$ & $46.2 \pm 19.1^{*}$ & $5.23 \mathrm{~cm} / 5.45 \mathrm{~cm}$ & $\begin{array}{r}\text { 1 Day } 8 \text { Hours/1 } \\
\text { Day } 6 \text { Hours }\end{array}$ \\
\hline
\end{tabular}

Such results shows the Mg-Zn alloy to possess the lowest corrosion rate as determined by Tafel extrapolation methods $19.5 \pm 5.3 \mathrm{~mm} \cdot \mathrm{yr}^{-1}$. Both $\mathrm{Mg}-\mathrm{Zn}-\mathrm{Se}$ and $\mathrm{Mg}-\mathrm{Zn}-\mathrm{Cu}$ possessed very similar electrochemical corrosion rates with $44.8 \pm 8.9 \mathrm{~mm} \cdot \mathrm{yr}^{-1}$ and 44.4 $\pm 14.9 \mathrm{~mm} \cdot \mathrm{yr}^{-1}$, respectively. Statistical difference was reached between the mean gravimetric corrosion rates $(\mathrm{p}=0.04)$ and the electrochemical corrosion rates $(\mathrm{p}=0.002)$ for the experimental alloys when tested using a single-factor ANOVA test with an alpha value of 0.05 . The corrosion rates determined by gravimetric weight loss methods 
showed very different results when compared to the resulting corrosion rates determined by electrochemical methods. Gravimetric tests, revealed the Mg-Zn alloy to possess a corrosion rate of $2.16 \mathrm{~mm} \cdot \mathrm{yr}^{-1}$, while the $\mathrm{Mg}-\mathrm{Zn}-\mathrm{Se}$ alloy had a lower corrosion rate of $0.428 \pm 0.190$. The $\mathrm{Mg}-\mathrm{Zn}-\mathrm{Cu}$ alloy showed to have a high calculated gravimetric degradation rate of $46.2 \mathrm{~mm} \cdot \mathrm{yr}^{-1}$, based upon a complete degradation period of 96 hours and an average mass of $214 \mathrm{mg}$. The percent difference between the mean corrosion rates determined by the gravimetric and electrochemical method for the $\mathrm{Mg}-\mathrm{Zn}$ alloy is $170 \%$, and $196 \%$ for the Mg-Zn-Se alloy.

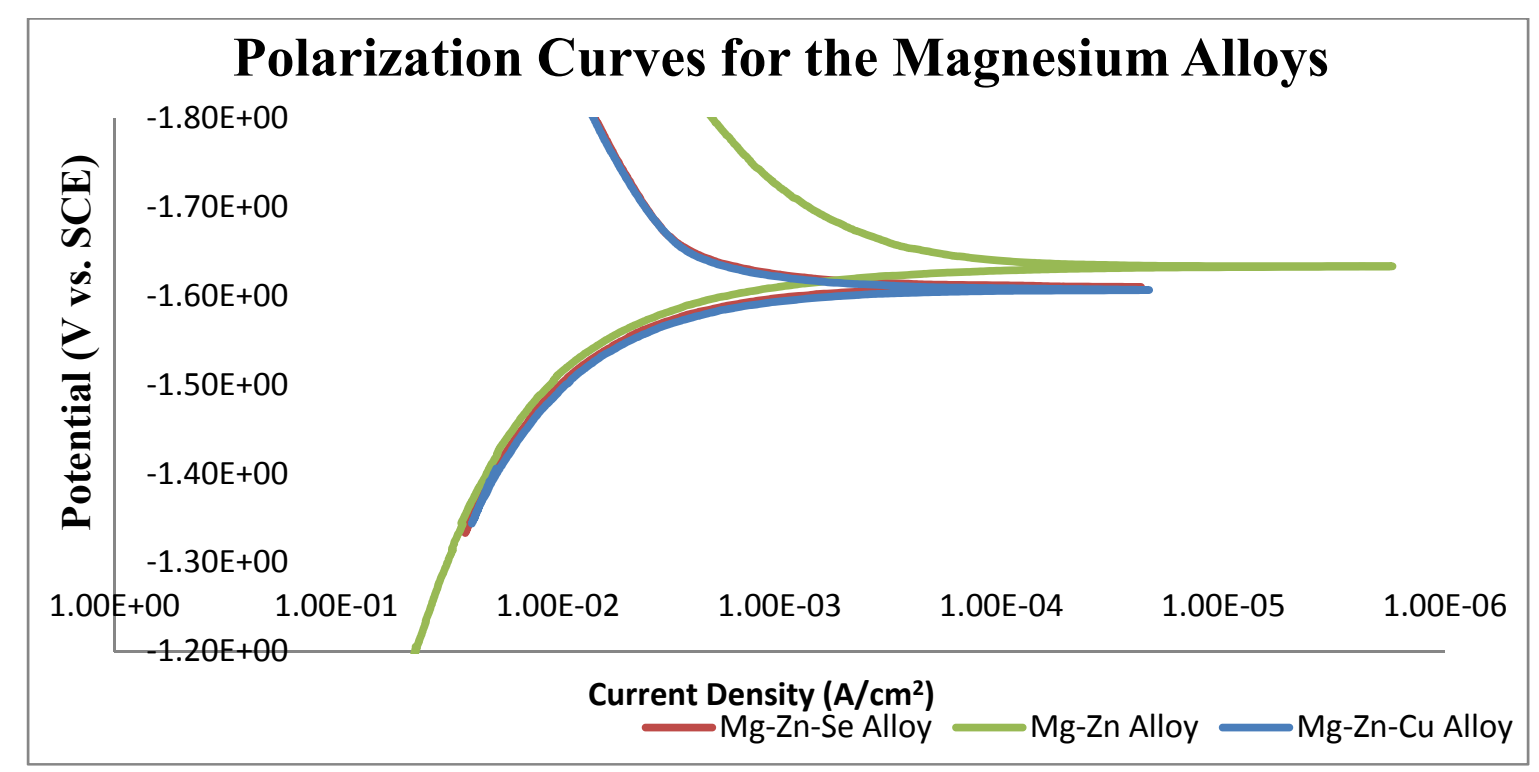

Figure 5-1. Tafel plots (Potential vs. Current density) for the experimental magnesium alloys tested in a static Kokubo solution at $37^{\circ} \mathrm{C}$. 


Figure 5-2. Images of a ternary magnesium alloys before and after immersion in Kokubo's solution for 30 days. A) Mg-Zn before immersion B) Mg-Zn after 30 days C) $\mathrm{Mg}-\mathrm{Zn}$-Se before immersion D) Mg-Zn-Se after 30 days E) $\mathrm{Mg}-\mathrm{Zn}-\mathrm{Cu}$ before immersion F) $\mathrm{Mg}-\mathrm{Zn}-\mathrm{Cu}$ after 30 days.

The Tafel plots for the experimental magnesium alloys, and a comparative commercially available $\mathrm{Mg}-\mathrm{Zn}$ alloys composition can be seen in Figure 5-1. It is seen that alloys $\mathrm{Mg}-\mathrm{Zn}$ and $\mathrm{Mg}-\mathrm{Zn}-\mathrm{Se}$ have rest potential values of about $-1.60 \mathrm{~V}$, which is greater than the $\mathrm{Mg}-\mathrm{Zn}-\mathrm{Cu}$ alloy with rest potential of about $-1.63 \mathrm{~V}$. Optical images of the magnesium alloys before and after immersion in the Kokubo's solution for 30 days are shown in Figure 5-2. Figures 5-2A, C, and E show Mg-Zn, Mg-Zn-Se, and Mg-Zn-Cu before immersion, respectively. It can be seen in these figures that the surfaces are very rough as they were only polished to a $\# 1200$ grit surface finish. Surface defects can be seen on the surface of all alloys, although $\mathrm{Mg}-\mathrm{Zn}-\mathrm{Cu}$ shows more pronounced pit defects (Fig. 5-2E). After the 30 day period of immersion both the $\mathrm{Mg}-\mathrm{Zn}$ and the $\mathrm{Mg}-\mathrm{Zn}-\mathrm{Se}$ alloys show a corroded surface. The Mg-Zn alloy shows a corroded surface with deep circular pit formations, whereas, the surface of the $\mathrm{Mg}$ - Zn-Se alloy shows less of such pit formation. 


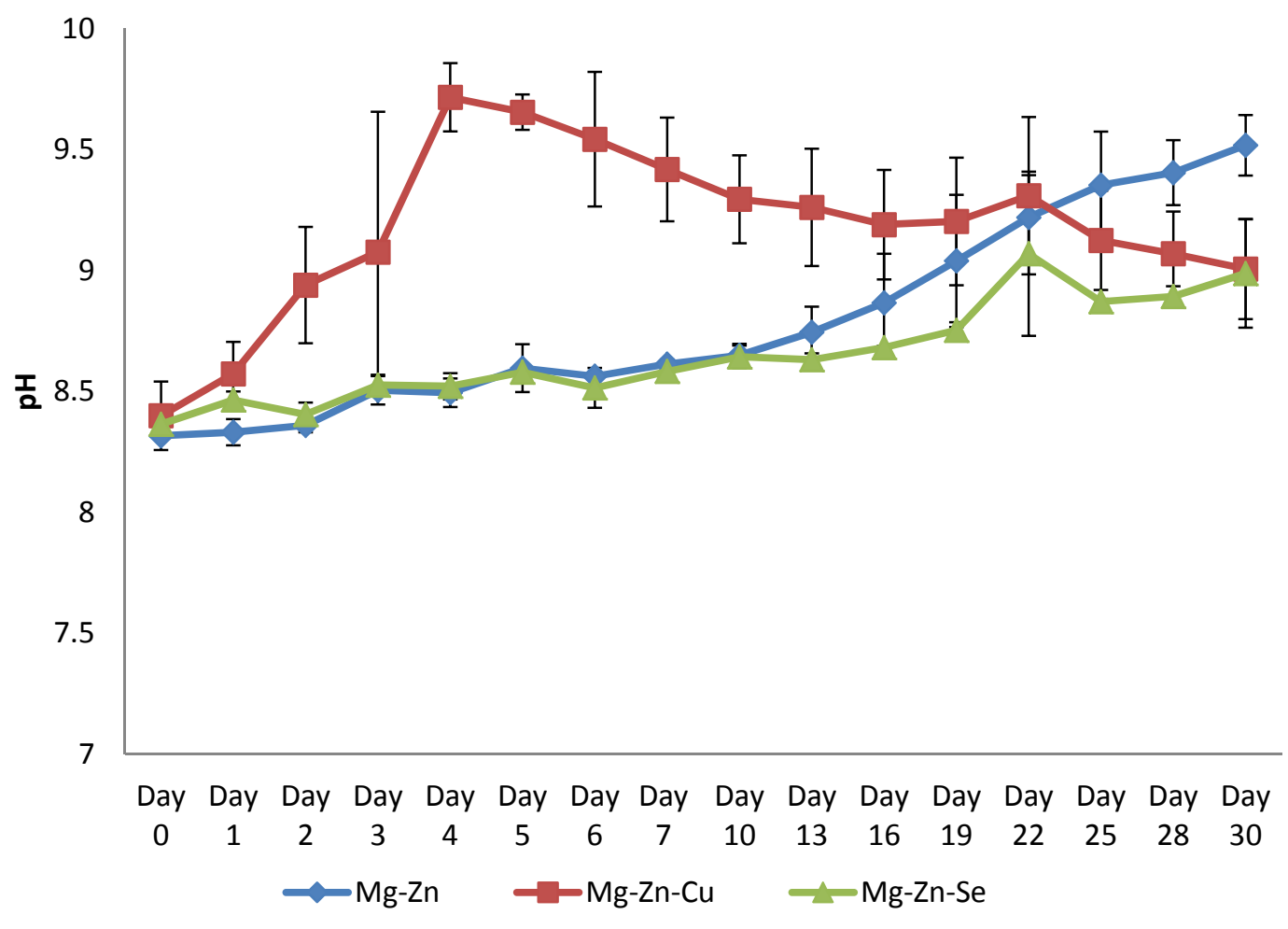

Figure 5-3. Changes in $\mathrm{pH}$ of Kokubo's solution with immersed magnesium alloys per day for 30 days. Data represented as mean \pm standard deviation. $\mathrm{N}=2$ (sample size).

The $\mathrm{pH}$ fluctuations of the SBF containing the magnesium alloys are shown in Figure 5-3. Both the $\mathrm{Mg}-\mathrm{Zn}-\mathrm{Se}$ and the $\mathrm{Mg}-\mathrm{Zn}$ alloys follow an increase in $\mathrm{pH}$ toward more basic values over the 30 day observation period, although Mg-Zn was shown to be 10x more basic than the Mg-Zn-Se alloy after 30 days (Fig. 5-3). The $\mathrm{pH}$ of the SBF for the $\mathrm{Mg}-\mathrm{Zn}-\mathrm{Cu}$ alloy shows a rapid increase in basicity immediately after immersion to day 4 , and then reversed the increase in acidity for the remaining 30 day duration. The differences in $\mathrm{pH}$ values of the leachate collected from the 30-day period of alloy immersion, reached statistical difference with a p-value of (0.0001), with evaluated with an alpha value of 0.05 when compared using a one-way ANOVA test. 
ICP-MS analysis was performed on aliquot samples of the SBF solution containing the immersed alloys from the gravimetric tests for every 24 hour period for the 30 day experimental duration. Results from these analyses can be seen in Figure 5-3. 

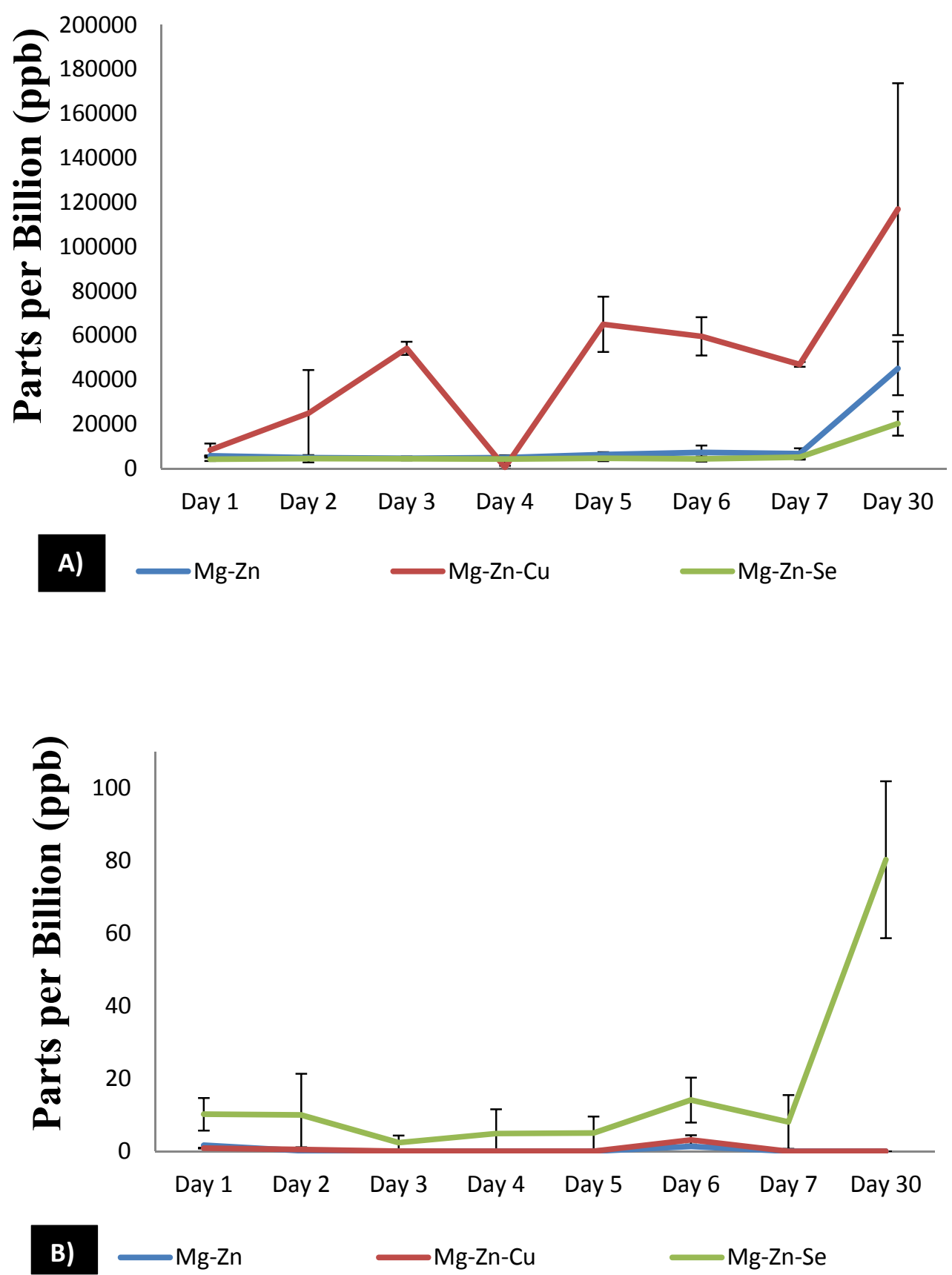

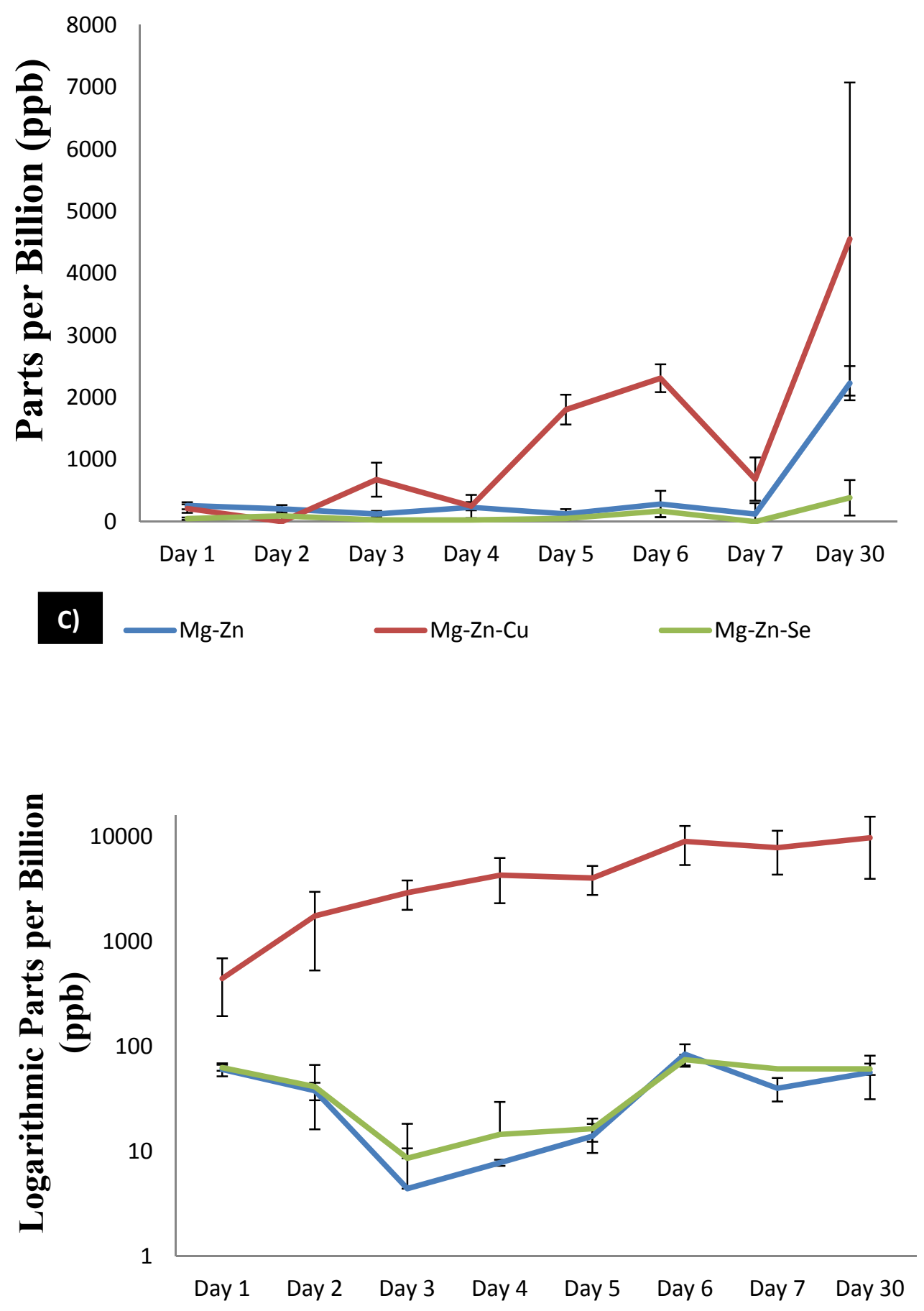

D) $\quad M g-Z n \quad M g-Z n-C u \quad M g-Z n-S e$ 


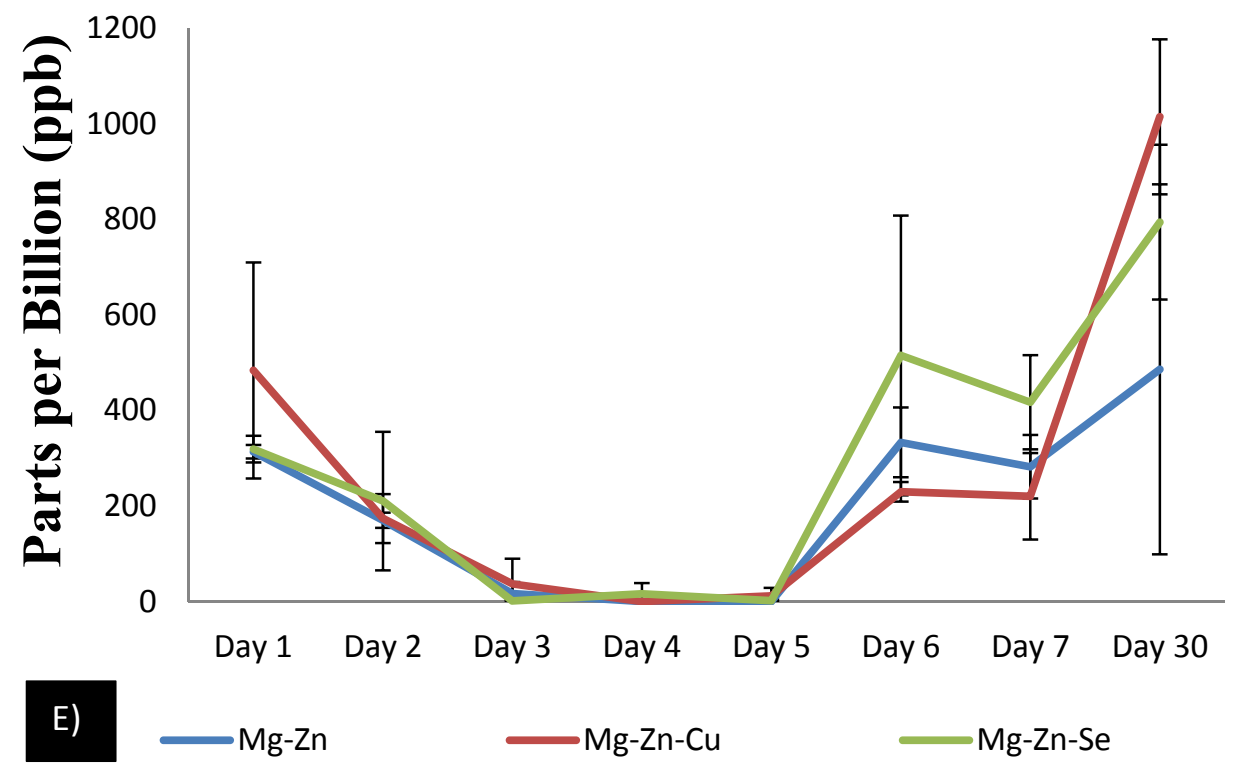

Figure 5-4. Concentration of ions eluted from magnesium alloys measured by inductively coupled plasma mass-spectrometry. A) Concentration of magnesium (II) ions, B) Concentration of selenium (IV) ions, C) Concentration of zinc (II) ions, D) Concentration of copper (II) ions, and E) Concentration of iron (II) ions. Data represented as mean \pm standard deviation. $\mathrm{N}=2$ (sample size). 
The concentration of $\mathrm{Mg}^{+2}$ ions released from the magnesium alloys during the 30 day experimental period is shown in Figure 5-4A. Consistent with the results from the gravimetric tests, the $\mathrm{Mg}-\mathrm{Zn}-\mathrm{Cu}$ alloy released the highest concentration of the $\mathrm{Mg}^{+2}$ ions of all alloys with final concentrations reaching $100 \mathrm{ppm}$. Whereas, $\mathrm{Mg}-\mathrm{Zn}$ and $\mathrm{Mg}-\mathrm{Zn}-\mathrm{Se}$ shows lower concentrations of $\mathrm{Mg}^{+2}$ ions $45 \mathrm{ppm}$ and 9 ppm, respectively. Figures 5-4B shows that the Mg-Zn-Se alloy released the greatest concentration of the $\mathrm{Se}^{+4}$ ions with slight increases in concentrations per day over the 30 day period. Figure 5-4C shows the release of $\mathrm{Zn}^{+2}$ ions from all magnesium alloys. It can be seen that the $\mathrm{Mg}-\mathrm{Zn}-\mathrm{Cu}$ alloy showed the highest release of the $\mathrm{Zn}^{+2}$ ions, which is expected as this alloy composition completely degraded. Similar to the release of $\mathrm{Mg}^{+2}$ ions from the alloys (Fig. 5-4A), the $\mathrm{Mg}-\mathrm{Zn}$ alloy was shown to release a higher concentration of $\mathrm{Zn}^{+2}$ ions as compared to the Mg-Zn-Se alloy, as seen in Figure 5-4C. The amount of $\mathrm{Cu}^{+2}$ ions released was nearly undetectable for the $\mathrm{Mg}-\mathrm{Zn}$ and the $\mathrm{Mg}-\mathrm{Zn}-\mathrm{Se}$ alloy. However, the $\mathrm{Mg}-\mathrm{Zn}-\mathrm{Cu}$ alloy showed to have substantially greater releases of $\mathrm{Cu}^{+2}$ ions over the 30 day period which is expected as the $\mathrm{Cu}$ is a major element in the $\mathrm{Mg}-\mathrm{Zn}-\mathrm{Cu}$ alloy matrix. To make the comparison of the $\mathrm{Cu}^{+2}$ ion concentrations, a logarithmic plot of the values are shown in Figure 5-4D. Of the common trace elements which are commonly detectable in magnesium alloys and are considered impurities (iron, aluminum, manganese, and nickel), only $\mathrm{Fe}^{+2}$ ions were detectable by mass spectrometry methods. Interestingly, Mg$\mathrm{Zn}-\mathrm{Cu}$ released the greatest concentration of $\mathrm{Fe}^{+2}$ ions over the 30 day period with concentration reaching $1000 \mathrm{ppb}, \mathrm{Mg}-\mathrm{Zn}-\mathrm{Se}$ reaching $400 \mathrm{ppb}$, and Mg-Zn releasing only a $200 \mathrm{ppb}$ at 30 days. 


\subsection{Discussion}

There exists a significant disparity in the corrosion rate of the alloys between the gravimetric and electrochemical methods. The main contributing factors of differences between the corrosion rates measured likely originate from the difference stirring rate (300 RPM orbital versus no stirring). According to Zhang (1996), two other contributing factors are 1) time effects (30 day exposure versus approximately 1 hour of exposure) and 2) regions of analysis selected on the Tafel plots made during the determination of $I_{\text {cor }}$ values [20]. Stern and Weisert, have shown that without precise knowledge of the Tafel slopes, corrosion rates can be estimated within a 50\% error with variation affecting corrosion rate $[21,22]$. Thus, such a phenomena cannot explain the percent differences of $170 \%$ and $196 \%$ for the $\mathrm{Mg}-\mathrm{Zn}$ and $\mathrm{Mg}-\mathrm{Zn}$-Se alloys, respectively. A more likely explanation for the large differences between the gravimetric corrosion rates and the electrochemical corrosion rates for the magnesium alloys is due to the differences in the experimental parameters used. Primarily, gravimetric testing used Dulbecco's solution as a SBF, whereas electrochemical testing used Kokubo's solution as a SBF. Comparatively, the ion concentrations between the elements of the Kokubo's solution and the Dulbecco's solution are very different. The higher ionic salt concentrations for ions like $\mathrm{Na}^{+}, \mathrm{Cl}^{-}$, and $\mathrm{HCO}_{3}{ }^{-}$found in the Kokubo's solution could attribute to the more aggressive corrosion rates for the experimental alloys as seen in the electrochemical testing results, because the electrolyte media provides for higher rates of oxidation of the testing specimen. Additionally, the effects of the vitamins and organic compounds found within Dulbecco's media on metal is not well understood. 
Another parameter that was not adequately controlled was the effects of stirring in the gravimetric tests and the static media conditions used in the electrochemical testing. Recognizing that conventional corrosion tests are not a true representation of in-situ conditions, gravimetric tests within this study were conducted under fluid conditions with a simulated wall shear stress of $14.5 \mathrm{dynes} / \mathrm{cm}^{2}$. Li et al., conclude that magnesium alloys under stirring conditions exhibited the lowest corrosion rate, while the flowing conditions promote local corrosion with rates three to six times faster than a stirred solution [8]. However, the two sets of data cannot truly be compared as the gravimetric tests were performed under dynamic conditions, whereas the electrochemical tests were performed under static conditions. This phenomenon would partially explain the lower corrosion rates seen for the $\mathrm{Mg}-\mathrm{Zn}$ and $\mathrm{Mg}-\mathrm{Zn}-\mathrm{Se}$ alloys when determined by gravimetric methods, as compared to electrochemically determined corrosion rates (Table 5-3). More so, the electrochemical corrosion rates determined for $\mathrm{Mg}-\mathrm{Zn}\left(19.5 \mathrm{~mm} \cdot \mathrm{yr}^{-1}\right), \mathrm{Mg}-\mathrm{Zn}-\mathrm{Se}(44.8$ $\left.\mathrm{mm} \cdot \mathrm{yr}^{-1}\right)$, and $\mathrm{Mg}-\mathrm{Zn}-\mathrm{Cu}\left(44.4 \mathrm{~mm} \cdot \mathrm{yr}^{-1}\right)$ are higher than pure $\mathrm{Mg}\left(0.09652 \mathrm{~mm} \cdot \mathrm{yr}^{-1}\right)$, AZ31 $\left(0.05842 \mathrm{~mm} \cdot \mathrm{yr}^{-1}\right)$, and AZ91D $\left(0.11938 \mathrm{~mm} \cdot \mathrm{yr}^{-1}\right)$ alloys reported by Xue et al [2]. However, these results cannot truly be compared because both testing conditions were different between the two experiments as Xue et al., used a phosphate buffer solution, and an exposed sample area of $20 \mathrm{~mm}^{2}$; whereas, the study presented herein, used a Kokubo's solution with a greater salt concentration and a exposed surface area of $25 \mathrm{~mm}^{2}$.

Another important parameter that was not accounted for during experimentation was that the partial pressure of oxygen $\left(\mathrm{pO}_{2}\right)$ and partial pressure of carbon dioxide $\left(\mathrm{pCO}_{2}\right)$ during the gravimetric tests did not compare to those that are normally found 
within the human body. Such parameters can greatly influence the corrosion rate of a metal. Bundy, highlights that sometimes an implant surface can be in contact with areas of different $\mathrm{pO}_{2}$, which would create the possibility for different aeration cells to develop [9]. This increased amount of oxygen species would lead to the formation of an oxide layer on the surface of the alloy, thus reducing the effects of corrosion. Whereas, a deaerated solution as was used for electrochemical testing, would inhibit an oxide layer from developing, leading to a more aggressively observed corrosion behavior. Likewise, $\mathrm{pCO}_{2}$ also influences the rate of corrosion because of its effects on the $\mathrm{pH}$ of the solution [9].

The corrosion and degradation time optimum for device self-removal is about 3-6 months, which is the period when arterial strength from wound healing is at its highest. Table 5-3 shows calculations for the expected strut thickness for a stent design with a targeted degradation period of 6 months when using the experimentally determined corrosion rates. It can be seen in the table that the Mg-Zn stent would require a strut thickness of $0.259 \mathrm{~cm}$ when using the gravimetric corrosion rate of $2.16 \mathrm{~mm} \mathrm{yr}^{-1}$. Comparatively, the Mg-Zn-Se alloys showed a require strut thicknesses that were much thinner at $0.051 \mathrm{~cm}$ with a gravimetric corrosion rate of $0.428 \mathrm{~mm} \mathrm{yr}^{-1}$. This would enable increased flexibility in the design of the stent and control of the degradation period with the amount of material that would be needed. Calculations were also performed to determine the degradation time, if the experimental alloys $\mathrm{Mg}-\mathrm{Zn}-\mathrm{Se}$ and $\mathrm{Mg}-\mathrm{Zn}-\mathrm{Cu}$ were manufactured into a commercially available stent. An example of such a device is the Cypher Stent ${ }^{\oplus}$ Johnson \& Johnson, which as a strut thickness of $0.016 \mathrm{~cm}$. It can be seen that a Cypher stent manufactured from the commercially available Mg-Zn alloy 
would degrade within 27 days, which does not meet the optimum time period of 3-6 months for wound healing to occur. Comparatively, a stent manufactured from the Mg$\mathrm{Zn}$-Se alloy would degrade within 136 days ( $\sim 5$ months), which is within the time period for wound healing to occur.

ICP-MS analysis on the samples revealed unexpected results for the solutions containing the $\mathrm{Mg}-\mathrm{Zn}-\mathrm{Cu}$ alloy. It was observed in such solutions that the concentrations of copper, magnesium, and zinc, continued to increase for the 30 day immersion period in SBF beyond the point of complete degradation for the alloy. The $\mathrm{Mg}-\mathrm{Zn}-\mathrm{Cu}$ alloy was seen to degrade completely around day 4 of the period, which is consistent with the $\mathrm{pH}$ trend which increases up to day 4 and then reduces back to neutrality for the remaining experimental period. The ICP-MS results that show the magnesium, zinc, and copper concentrations increasing beyond day 4 can be explained by a transitional state of the alloy degrading into a precipitate or residue in the SBF that continues to exchange ions within solution with other elemental species to continuously release ions. The increased ion concentration is what is detected by the ICP-MS analysis as the 30 day period progresses.

Additionally, ICP-MS detected $\mathrm{Fe}^{+2}$ ions in solutions obtained from all the magnesium alloys. This shows that $\mathrm{Fe}^{+2}$ is a common impurity that is difficult to remove during the alloy forming process. The ionic concentration of the $\mathrm{Fe}^{+2}$ ions seen in the magnesium alloys (Mg-Zn-Cu $>\mathrm{Mg}-\mathrm{Zn}-\mathrm{Se}>\mathrm{Mg}-\mathrm{Zn})$, correlate to their electrochemically determined corrosion rate.

Future experimentation would improve upon the data obtained from experimentation presented in this dissertation mainly through the use of more 
representative bio-corrosion studies of the human body for biomaterial testing. Such improvements would include performing both electrochemical and gravimetric techniques using aerated SBF solutions, as well as varying the types of electrolyte solutions used for corrosion to include water, Kokubo's solution, and a conventionally used SBF. More so, a parallel set of experiments should be conducted which explores the same parameters listed above, under varying degrees of media conditions such as stirring, static and flow conditions.

\subsection{Conclusions}

In this work, the corrosion behavior of $\mathrm{Mg}-\mathrm{Zn}-\mathrm{Se}$ and $\mathrm{Mg}-\mathrm{Zn}-\mathrm{Cu}$ alloys was investigated to assess the potential of these alloys to serve as implantable biomaterials. Designing experimental magnesium alloys to include $1 \mathrm{wt} . \%$ of $\mathrm{Cu}$ and Se, allow for the gross effects of the materials alloying elements to be determined through biocompatibility testing and corrosion analysis. In this paper, the corrosion behavior of these experimental alloys was shown to have a more aggressive corrosion behavior than pure $\mathrm{Mg}$, and other as-cast AZ31 and AZ91D alloys when determined by electrochemical testing. However, a comparison between such results is not accurate, because the testing parameters for the experiments are different (aeration vs. deaeration, SBF compositions, stirring vs. static). Independent electrochemical results show that the $\mathrm{Mg}-\mathrm{Zn}-\mathrm{Se}$ and $\mathrm{Mg}$ $\mathrm{Zn}-\mathrm{Cu}$ have an aggressive initial corrosion rate. While, gravimetric tests show the $\mathrm{Mg}$ $\mathrm{Zn}$-Se alloy to be corrosion resistant. In both tests, $\mathrm{Mg}-\mathrm{Zn}-\mathrm{Cu}$ showed to possess the highest corrosion rate. 


\subsection{References}

1. Persaud-Sharma, D., Budiansky, N., McGoron, A.J. Mechanical properties and tensile failure analysis of novel bio-absorbable $\mathrm{Mg}-\mathrm{Zn}-\mathrm{Cu}$ and $\mathrm{Mg}-\mathrm{Zn}-\mathrm{Se}$ alloys for endovascular applications. Metals. 2013; 3: 23-40.

2. Xue, D., Yun, Y., Tan, Z., Dong, Z., Schultz, M. In Vivo and In Vitro degradation behavior of magnesium alloys as biomaterials. Journal of Materials Science and Technology. 2012; 3: 251-267.

3. Song, G., Atrens, A. Understanding magnesium corrosion-a framework for improved alloy performance. Advanced Engineering Materials. 2003; 5: 837858 .

4. Zeng, R.C., Dietzel, W., Witte, F., Hort, N., Blawert, C. Progress and challenges of magnesium alloys as biomaterials. Advanced Engineering Materials. 2008; 10: B3-B14.

5. Staiger, M.P., Pietak, A.M., Huadmai, J., Dias, G. Magnesium and its alloys as orthopedic biomaterials: a review. Biomaterials. 2006; 27: 1728-1734.

6. Persaud-Sharma, D., McGoron, A. Biodegradable magnesium alloys: a review of material development and applications. Journal of Biomimetics, Biomaterials, \& Tissue Engineering. 2012; 12: 25-39.

7. Poinern, G.E.J., Brundavanam, S., Fawcett, D. Biomedical magnesium alloys: a review of material properties, surface modifications, and potential as a biodegradable orthopedic implant. American Journal of Biomedical Engineering. 2012; 2: 218-240.

8. Li, N., Guo, C., Wu, Y.H., Zheng, Y.F., Ruan, L.Q. Comparative study on corrosion behavior of pure $\mathrm{Mg}$ and WE43 alloy in static, stirring and flowing Hank's solution. Corrosion Engineering, Science and Technology. 2012; 47: 346351.

9. Bundy, K.J. (2005). Corrosion testing in In Vivo environments. In R. Baboian, Corrosion tests and standards: application and interpretation (pp. 500-508). USA:ASTM international.

10. Williams, R.L., Brown, S.A., Merritt, K. Electrochemical studies on the influence of proteins on the corrosion of implant alloys. Biomaterials. 1988; 9: 181-186.

11. Gu, X.N., Zheng, Y.F., Chen, L.J. Influence of artificial biological fluid composition on the biocorrosion of potential orthopedic Mg-Ca, AZ31, AZ91 alloys. Biomedical Materials. 2009; 065011. 
12. Sun, D., Wharton, J.A., Wood, R.K.J. Effects of proteins and pH on tribocorrosion performance of cast CoCrMo- a combined electrochemical and tribological study. Tribology. 2008; 2: 150- 160.

13. Kokubo, T., Kushitani, H., Sakka, S., Kitsugi, T., Yamamuro, T. Solutions able to reproduce in vivo surface-structure changes in bioactive glass-ceramic A-W. Journal of Biomedical Material Research.1990; 24: 721-734.

14. Dulbecco's modified eagle's medium liquid formulation, Hyclone Thermo Scientific (SH30081).

15. Paszkowiak, J.J., Dardik, A. Arterial wall shear stress: observations from the bench to the bedside. Vascular and Endovascular Surgery. 2003; 37: 37-47.

16. Lipowsky, H.H. Shear stress in the circulation. American Physiological Society. In: Flow Dependent Regulation of Vascular Function, ed. by Bevan JA. Oxford: University Press, 1995: 28-45.

17. Malek A.M., Alper, S.L., Izumo, S. Hemodynamic shear stress and its role in atherosclerosis. Journal of the American Medical Association. 1999; 282: 20352042.

18.Persaud-Sharma, D., McGoron, A.J. Biodegradable Magnesium Alloys: A Review of Material Development and Applications. Journal of Biomimetics,Biomaterials \& Tissue Engineering. 2011; 12: 25-39.

19. Witte, F., Hort, N., Vogt, C., Cohen, S., Kainer, K., Willumeit, R., Feyerabend, F. Degradable Biomaterials Based on Magnesium. Current Opinion in Solid State and Material Science. 2008; 12: pp. 63-72.

20. Zhang, X.G. Corrosion and electrochemistry of Zinc. 1996, Plenum Press. N.Y., N.Y., U.S.A.

21. Stern, M., Weisert, E.D. Experimental observations on the relation between polarization resistance and corrosion rate. Proceedings of the American Society for Testing and Materials. 1959; 59: 1280-1291.

22. Pardo, A., Feliu, S., Merino, M.C., Arrabal, R., Matykina, E. Electrochemical estimation of the corrosion rate of Magnesium/Aluminum alloys. International Journal of Corrosion. 2010: 1-8.

23. ASTM F2129 - 08 Standard Test Method for Conducting Cyclic Potentiodynamic Polarization Measurements to Determine the Corrosion Susceptibility of Small Implant Devices. 
24. ASTM G102 - 89(2010) Standard Practice for Calculation of Corrosion Rates and Related Information from Electrochemical Measurements. 


\section{CHAPTER 6 \\ SUMMARY}

Magnesium alloys have been widely explored as potential biomaterials, but several limitations to using these materials, such as their uncontrollable degradation kinetics and poor mechanical properties, have prevented their widespread use. In an attempt to further the applicability of magnesium and its alloys for biomedical purposes two novel magnesium alloys, $\mathrm{Mg}-\mathrm{Zn}-\mathrm{Cu}$ and $\mathrm{Mg}-\mathrm{Zn}-\mathrm{Se}$, were developed with the expectation of improving upon the unfavorable qualities shown by similar magnesium based materials that have previously been explored.

The mechanical properties of the novel magnesium alloys $\mathrm{Mg}-\mathrm{Zn}-\mathrm{Cu}$ and $\mathrm{Mg}-\mathrm{Zn}$ Se were characterized and evaluated through a series of mechanical testing procedures. Experimental results from these tests show that the developed magnesium alloys show promise for applications as endovascular medical devices as they possess comparable mechanical properties to Nitinol, Pt-10Ir, and the Mg-3A1-1Z alloy. The Mg-Zn-Se and $\mathrm{Mg}-\mathrm{Zn}-\mathrm{Cu}$ alloys were shown to have higher elongation at failure than other as-cast magnesium alloys currently being explored for endovascular device applications, such as the WE43, AZ63, and ZE41 compositions to name a few. The higher elongation at failure values for $\mathrm{Mg}-\mathrm{Zn}-\mathrm{Se}$ and $\mathrm{Mg}-\mathrm{Zn}-\mathrm{Cu}$ alloys would permit for greater ductility of the materials which is important as it relates to defining the stress-limits during the extrusion process of forming a stent. In addition, the higher ductility would facilitate deformation during stent deployment reducing the risk of cracking/failing. Both of the experimental alloys possess air-formed oxide layer modulus of elasticity values that are greater than the values for the bulk metal. This hardened protective covering of the bulk material may 
provide protection against corrosion and impact the wear and friction behavior of the alloys. Additionally, such hardened oxide layers may initiate cracks on the surface of the alloys resulting in enhanced oxidation of the bulk metal. Further research is needed to understand the behavior of the mechanical properties of the oxide layer and crack propagation.

The biocompatibility experimentation of the Mg-Zn-Se alloy showed that they induced less toxicity than both the Mg-Zn-Cu alloy and the commercially available Mg$\mathrm{Zn}$ alloy. On the other hand, the Mg-Zn-Cu alloy was more toxic to the human foreskin fibroblast cells at a level not conducive with cell survival. It was also observed that cells did not grow in direct contact with any of the three magnesium alloy compositions which can be attributed to hydrogen gas produced from the alloys and the hydroxide precipitate formations which create a $\mathrm{pH}$ environment not conducive to cell growth. This is a very common phenomenon for magnesium alloys in general. This may be a desirable quality for endovascular applications, as the likelihood for thrombosis and intra-stent restenosis to develop may be minimalized.

One of the key limitations of currently available magnesium alloys is the high corrosion rates in-vivo leading to premature device degradation. The Mg-Zn-Se alloy possesses a gravimetric corrosion rate that is lower than the commercially available Mg$\mathrm{Zn}$ alloy. The corrosion rate for the Mg-Zn-Se alloy is suitable to achieve a 1-3 month device lifetime based on currently available device designs (e.g., leg thickness). Conversely, the $\mathrm{Mg}-\mathrm{Zn}-\mathrm{Cu}$ alloy may not be suitable for stenting applications as an ascast alloy because its gravimetric and electrochemically determined corrosion rates are higher, which would result in premature failure. A more likely application for the Mg-Zn- 
$\mathrm{Cu}$ alloy may lie in short-term applications such as orthopedic screws or staples. This would be suitable as the $\mathrm{Mg}-\mathrm{Zn}-\mathrm{Cu}$ alloys could degrade and be removed from the site within a short-period of time without the need for surgical removal. The future work for these experimental alloys lies in controlling the corrosion behavior of these materials. The corrosion rates of these materials were determined based upon in-vitro conditions, and not exact representations of in-situ performance. Future work may include animal studies testing the performance of vascular stents manufactured from the experimental materials. Additional work may include exploring the creation of a biocorrosion system to assess the performance of the experimental alloys, as well as a means of controlling the corrosion rate of the materials to achieve targeted periods of degradation. 
VITA

\section{DHARAM PERSAUD-SHARMA}

$2005-2007$

$2007-2008$

$2009-2010$

$2010-2013$
BSc., Biomedical Science/Biomedical Physics University of South Florida

Tampa, FL, USA

Medical Physics Fellowship

Sylvester Comprehensive Cancer Center

University of Miami

Coral Gables, FL, USA

M.S.B.E., Biomedical Engineering

Florida International University

Miami, FL, USA

Doctoral Candidate, Biomedical Engineering

Florida International University

Miami, FL, USA

\section{PUBLICATIONS AND PRESENTATIONS}

Persaud-Sharma, D. Determination of the Mechanical Properties of Ternary Nitinol Alloys. Presented at the BioInterface Conference, October, 2010, Atlanta, GA, USA.

Persaud-Sharma, D., McGoron, A. Biodegradable Magnesium Alloys: A Review of Material Development and Applications. Journal of Biomaterials, Biomimetics, and Tissue Engineering. 2012; 16: 55-69.

Persaud-Sharma, D., Budiansky, N., McGoron, A. Mechanical Properties and Tensile Failure Anlaysis of Novel Bio-Absorbable $\mathrm{Mg}-\mathrm{Zn}-\mathrm{Cu}$ and $\mathrm{Mg}-\mathrm{Zn}-\mathrm{Se}$ Alloys for Endovascular Applications. Metals. 2013; 3: 23-40.

Persaud-Sharma, D., Budiansky, N., McGoron, A. Biocompatibility Assessment of Novel Bioresorbable Alloys $\mathrm{Mg}-\mathrm{Zn}-\mathrm{Se}$ and $\mathrm{Mg}-\mathrm{Zn}-\mathrm{Cu}$ for Endovascular Applications: In- Vitro Studies. 2013; 17: 25-45. Journal of Biomimetics, Biomaterials, and Tissue Engineering.

Persaud-Sharma, D. Pedagogical Methods to Promote STEM Literacy. [In-press] The International Journal of Science, Mathematics, Engineering, and Technology Learning. 